\title{
Families in Focus: New Perspectives on Mothers, Fathers, and Children
}

Judith Bruce

Population Council

Cynthia B. Lloyd

Population Council

Ann Leonard

Patrice L. Engle

Niev Duffy

Follow this and additional works at: https://knowledgecommons.popcouncil.org/departments_sbsr-pgy

Part of the Demography, Population, and Ecology Commons, Family, Life Course, and Society

Commons, International Public Health Commons, Maternal and Child Health Commons, Medicine and Health Commons, and the Women's Health Commons How does access to this work benefit you? Let us know!

\section{Recommended Citation}

Bruce, Judith, Cynthia B. Lloyd, Ann Leonard, Patrice L. Engle, and Niev Duffy. 1995. "Families in Focus: New Perspectives on Mothers, Fathers, and Children." New York: Population Council. 


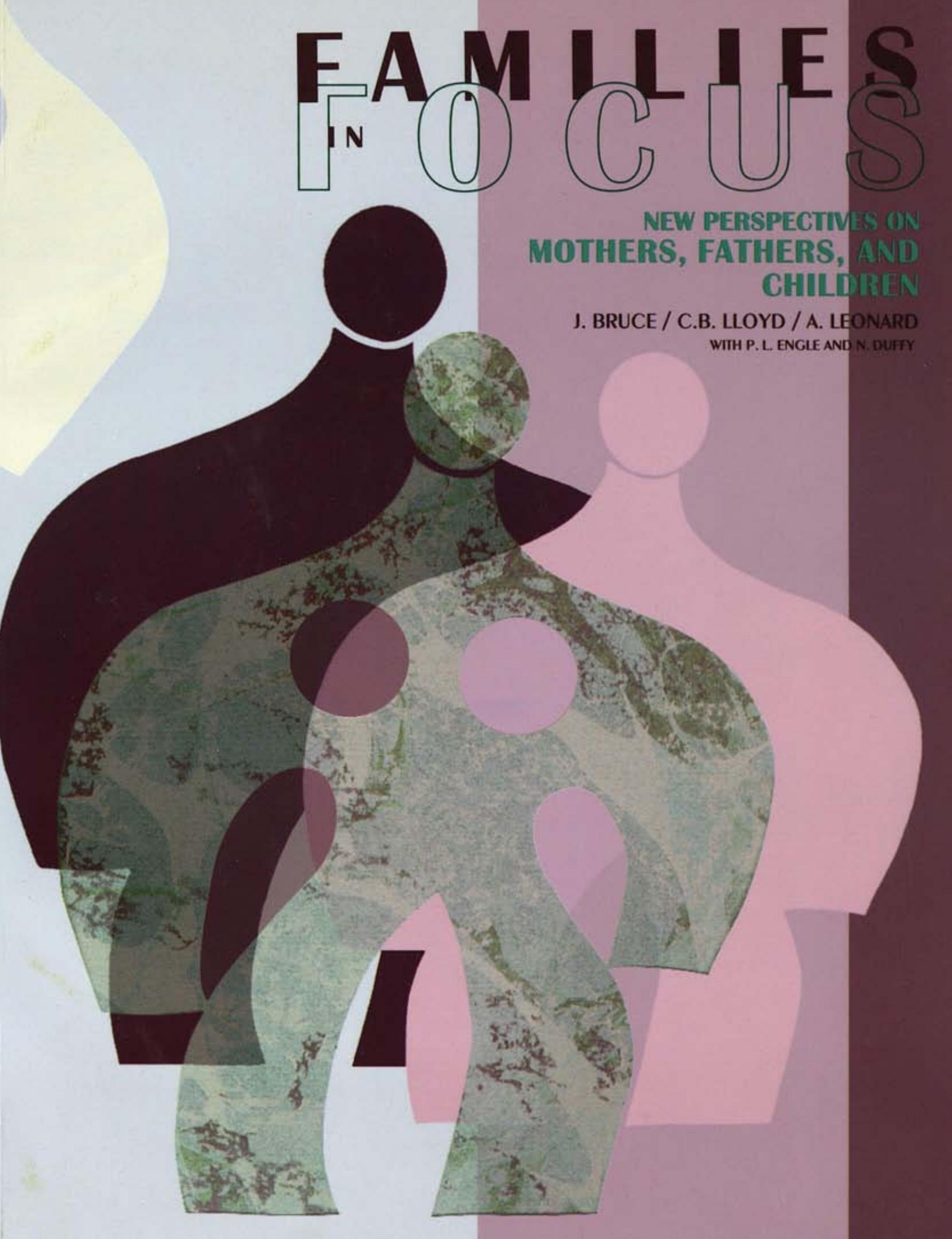



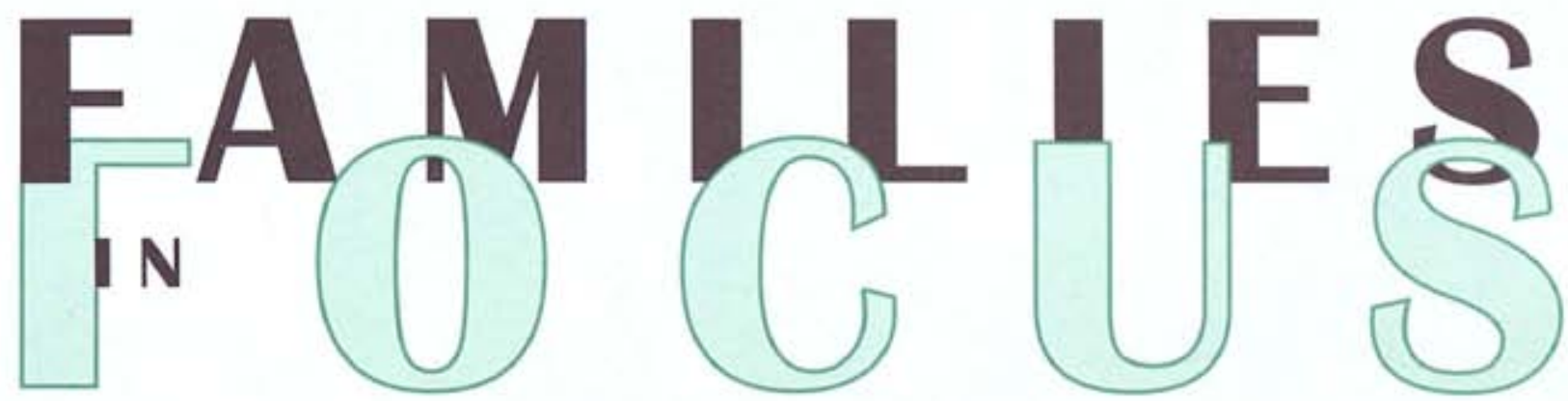

NEW PERSPECTIVES ON MOTHERS, FATHERS, AND CHILDREN

Judith Bruce, Cynthia B. Lloyd, and Ann Leonard with Patrice L. Engle and Niev Duffy

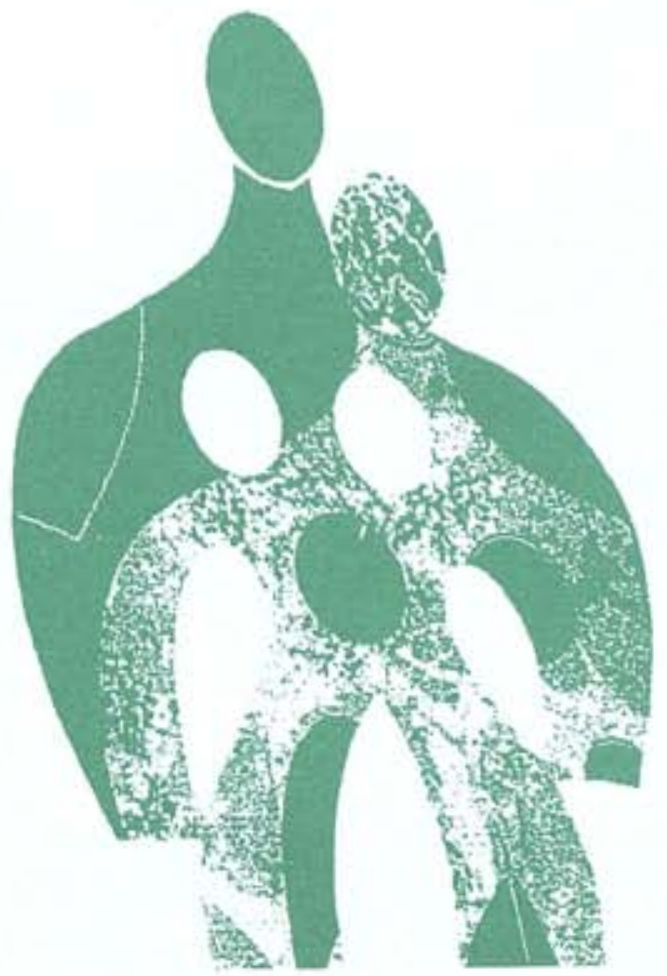


Library of Congress Cataloging-in-Publication Data

Bruce, Judith.

Families in focus: new perspectives on mothers, fathers, and children / Judith Bruce, Cynthia B. Lloyd, and Ann Leonard, with Patrice L. Engle and Niev Duffy.

p. $\mathrm{cm}$.

ISBN 0-87834-084-X (alk. paper)

1. Family. 2. Family-Economic aspects. 3. Family demography. 4. Family policy. I. Lloyd, Cynthia B. II. Leonard, Ann. III. Title.

HQ518.B77 1995

$306.85-\mathrm{dc} 20$

95-3862

CIP

Copyright $(1) 1995$ by The Population Council, Inc.

All rights reserved.

Printed in the United States of America on recycled paper.

Editor: Judith Anderson Masslo

Cover and text design: Diana Hrisinko

Photo Credits: p. 4 UNICEF/Nicole Toutounji (Haiti)

p. 24 United Nations/Kay Muldoon (Mali)

p. 48 UNICEF/Sean Sprague (Egypt)

p. 70 Ann Leonard (India)

p. 94 United Nations/L. Rajaonina (Tanzania)

THE POPULATION COUNCIL

ONE DAG HAMMARSKJOLD PLAZA

NEW YORK, NEW YORK 10017 USA 


\section{O N T E N TS}

List of Tables $v$

Acknowledgments viii

Introduction I

Judith BRUCE, CYNTHIA B. LLoYd, AND ANn LeONARD

Chapter 1 Families in Transition 5

CYNTHIA B. LLOYD AND NIEv DUfFY

Later marriage and childbirth 5

Smaller families and households 6

Increasing dependency burden on working-age parents 14

Increasing proportion of female-headed households 14

Shifting balance of economic responsibility in families 20

Conclusion 21

Chapter 2 The Economics of Motherhood 25 JUDITH BRUCE

Prevalence of mother-supported families 25

Wage-earning and domestic work: mothers' dual productive duties 27

Mothers' cash income: a family necessity 29 
Pathways to single motherhood 34

Women's unexpected economic life cycles 39

Marriage and motherhood as free choices 41

Conclusion 42

Chapter 3 Fathers as Parenting Partners

PATRICE L. ENGle AND ANN LeONARD

Fatherhood defined 50

Fathers' contributions to direct child care: the empirical record 50

Factors affecting father-child relationships 53

Benefits of father-child involvement 59

Continuing the discourse on fathers: innovative measures 61

Conclusion 63

Chapter 4 Familial Risk Factors

for Children 71

Cynthia B. Lloyd and Niev Duffy

Birth circumstances 72

Primary family relationships 76

Children's living arrangements 84

Conclusion 89

Chapter 5 Family Policy: Supporting the

Parent-Child Link 95

JUDITH BRUCE

Family relationships: the missing policy link 97

Facts about families with children: diversity and change 98

Seeking the ties that bind: the argument for research 99

Supporting the ties that bind: the argument for action 101

Practical policies and programs: creating pathways for effective sharing 105

Conclusion 113 


\section{LIST OF TABLES}

Chapter I - FAMILIES

TABLE I

Trends in percent of women aged 20-24 who have never been married (illustrative data) 7

TABLE 2

Trends in age of mother at first birth (illustrative data) 8

TABLE 3

Trends in percent of ever-married women aged $40-44$ with five or more living children in less developed countries (illustrative data) 9

TABLE 4

Trends in numbers of children ever born and surviving children for women aged 40-44 in less developed countries (illustrative data) $\quad 10$

TABLE 5

Trends in average household size in developed countries (illustrative data) 11

TABLE 6

Trends in household size in less developed countries (illustrative data) $\quad 12$

TABLE 7

Trends in percent of households headed by women de jure (all available data) $\quad 16-17$ 
TABLE 8

Trends in single-parent households as a percent of all households with dependent children and at least one resident parent in developed countries (illustrative data) 18

TABLE 9

Percent of first marriages dissolved through separation, divorce, or death among women aged $40-49$ in less developed countries (illustrative data) 19

TABLE 10

Trends in divorce rates per 100 marriages in developed countries (illustrative data) 20

Chapter 2 - MOTHERS

TABLE I

Differences in men's and women's weekly work hours by living arrangement in Ghana, 1987/88 30

TABLE 2

Wives' and husbands' average monthly income contributions to the household in six villages in South India 32

TABLE 3

Percent of women aged 35-39 in polygamous unions in less developed countries (illustrative data) 36

TABL 4

Percent of currently married women living apart from their husband in African countries (illustrative data) 38

TABLE 5

Percent of time women aged 20-49 spend unmarried in less developed countries (all available data) 40

Chapter 3 - FATHERS

TABLE I

Mean hours spent in direct child care per week (illustrative data) 52 
Chapter 4 - CHILDREN

TABLE ।

Nonmarital births as a percent of all births by region (country averages) 73

TABLE 2

Premarital births as a percent of all births to women under age 20 in sub-Saharan Africa (all available data) 74

TABLE 3

Births to married couples after last desired birth as a percent of all births in less developed regions 76

TABLE 4

Trends in unwanted births as a percent of all births in less developed countries (all available trend data) 77

TABLE 5

Percent of children aged 0-15 with mothers in given marital categories in less developed countries (illustrative data) 79

TABLE 6

Poverty and low income among children by family type (all available data) 80

TABLE 7

Percent of children who are stunted by mother's marital status in Latin America and West Africa (illustrative data) 82

TABLE 8

Percent of children living away from their mother by age of child in less developed countries (illustrative data) 85

TABLE 9

Percent of childhood years spent living with a mother but without a father in less developed countries (illustrative data) 87 


\section{A C K N O W LED G M E N T S}

THIS BOOK IS truly a collaborative effort and would not have reached fruition without the generosity of spirit and intellect of many people. Some years ago the Population Council and the International Center for Research on Women (ICRW) collaborated on a program of study of the determinants and consequences of female-headed households. Inspired by findings on changing family structures, consequent demands for greater economic contributions by women, and the effects of these phenomena on children, the Council broadened its scope to examine more closely the situation of mothers, fathers, and children in today's changing world.

Special thanks, of course, go to the donors who made the whole exercise possible - The Ford Foundation, United Nations Population Fund (UNFPA), United Nations Children's Fund (UNICEF), and United Nations Development Fund for Women (UNIFEM) — and to the members of our advisory committee for their assistance in reviewing and critiquing chapters and providing guidance throughout: Beti Astolfi, Mayra Buvinić, Betsy Campbell, Marilyn Carr, Ruth Dixon-Mueller, Misrak Elias, Sreelakshmi Gururaja, Cassie Landers, Catherine Pierce, Margaret Snyder, Andrea Taylor, and Joann Vanek.

In addition to members of the advisory committee, a number of colleagues served as readers for various chapters, including Krishna Bose, Katharine Briar, Marty Chen, Nick Danforth, Ross Danielson, John Donohue, Nancy Folbre, Jodi Jacobson, Elise Jones, Frank Karel, Anne Kubisch, Joanne Leslie, Richard Longhurst, Jill Merrick, Robert Myers, Michael Paolisso, and Danielle Parris. Ruth Dixon-Mueller helped lay the groundwork for several chapters; Joann Vanek was tremendously helpful in identifying sources of data as well as providing moral support; Jodi Jacobson 
provided editorial input midway through the project; and Elizabeth Kirberger did considerable research on the rights of children internationally. Kirsten Moore assisted in administering the project; Susan Rowe checked references; Kristin Morrell input edits and checked and formatted references; Diane Rubino rendered the tables; Matt Burkhard, Sheryl Jones, and Kristine Malden helped with inputting and revising the text; and Robert Heidel copyedited the text. Design of the publication is a reflection of the creative talent of Diana Hrisinko. Thanks are also extended to George Brown and Monica Knorr for their help and encouragement in moving the project forward.

Finally, and most importantly, we thank the editor of this volume, Judith Anderson Masslo, who took on the enormous task of transforming the authors' work into one cohesive document. Her significant written and conceptual contributions to the book, extraordinary attention to detail, understanding of the purpose and values underlying this work, and sensitivity to its different voices are greatly appreciated. 


\section{In t r o d u c t i o n}

\section{Judith Bruce, Cynthia B. Lloyd, and Ann Leonard}

While various forms of the family exist in different social, cultural, legal and political systems, the family is the basic unit of society and as such is entitled to receive comprehensive protection and support.

- Programme of Action of the United Nations International Conference on Population and Development

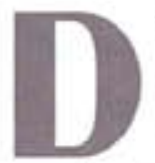

espite the rhetoric of recent years lamenting the loss of the "traditional family," families have never fit nicely into any single model.

"Family" may refer to people linked by marriage or kinship or to people claiming descent from common ancestors in a lineage, tribe, or clan. People may form and extend families by adopting or fostering children, defining non-relatives as family, or establishing consensual partnerships.

Families are as adaptable as they are diverse, re-configuring themselves over their life cycles and evolving to accommodate the myriad pressures of the external world. But while families have always been characterized by change, there is strong evidence that they are changing faster today than ever before.

This book focuses on families with dependent children - specifically, on the roles of mothers, fathers, and children, and how these roles are evolving. We do not discount the value of understanding more about how the elderly are cared for, the role of extended kin in the support of children, the intricacies of sibling relationships, and the creative power of friendship to provide some of the comforts of family. Our primary emphasis, however, is on how fathers and mothers meet their parental responsibilities and, in turn, what children have a right to expect from their parents. 


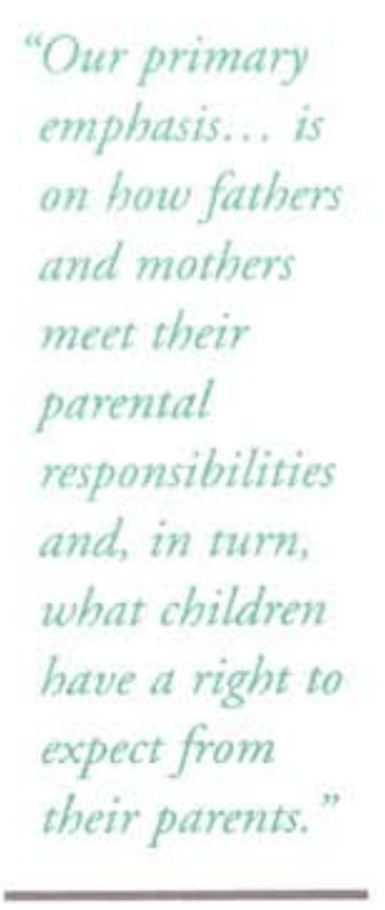

The designation of 1994 as the International Year of the Family, the convening of the International Conference on Population and Development in 1994, and the convening of the first World Summit for Social Development and Fourth World Conference on Women in 1995 (all United Nations initiatives) provide an opportunity to re-examine commonly accepted beliefs about the family. In doing this, one must confront a dominant myth that the "traditional family" is a stable and cohesive unit in which father serves as economic provider, mother serves as emotional caregiver, and all children are treated equally and well. In reality, mothers throughout the world play an essential, oftentimes primary, role in the economic support of other family members, especially children; fathers have vital roles to play in their children's lives in addition to supporting them economically; and children's family circumstances often contrast sharply with nostalgic visions of childhood security and stability.

Setting the stage for a discussion of the realities of mothers', fathers', and children's lives, Chapter 1 presents a demographic and economic analysis of how families throughout the world are changing in form and function. Data gathered over the last two decades indicate five global trends: 1) families and households have gotten smaller; 2 ) the burden on working-age parents of supporting younger and older dependents has increased; 3) women's average age at first marriage and childbirth has risen; 4) the proportion of female-headed households has increased; and 5) women's participation in the formal labor market has increased at the same time that men's has declined, shifting the balance of economic responsibility in families. These trends are profoundly altering the patterns of contact and sharing in families.

Chapter 2 documents the economics of motherhood, showing that most families depend - probably increasingly so - on mothers' paid and unpaid work in the home and labor market to survive. Chapter 3 shows that fathers' roles in nurturing and caring for children have been almost totally neglected as a subject of research, policy, and programs; yet there are promising signs of growing interest in the father-child link. Chapter 4 presents an empirical analysis of family life from the child's point-of-view - an original contribution of this volume. New data indicate that a range of birth and family circumstances put children at risk, including: being born out-of-wedlock or being unwanted at birth; having parents who are deceased, not currently married, not formally married, or in a polygamous union; living away from one's mother or father; and having parents who have migrated.

In researching this book we found ourselves hindered by the very myths about mothers, fathers, children, and families that we seek to challenge. Much of the conventional data from demographic and health surveys are lim- 
"The parent-child

relationship is the

fundamental

building block

of human society:

if it is broken

under the assault

of misguided

policies, little

else will be left

to lose." ited by a narrow focus on households and reproductive-age women and by a lack of attention to fathers and family relationships. As a result we now have many elaborate descriptions of women's fertility and mothering up to age 49, but negligible information about mothering beyond the age of 49 , male fertility and fatherhood, and family relationships that transcend household boundaries. Data on households tell us less and less about families as family members become more dispersed. Household headship data underrepresent the number of families supported primarily or solely by women, often mothers. Data on household structure serve as a poor proxy for information about family functioning: For example, a child with married parents who live together may not necessarily be well cared for, while a child with divorced parents may thrive if both parents nurture and support the child. Information about children's living arrangements, family relationships, and sources of economic support is scant compared to the relatively robust data on their health and participation in school. Little is known about women's work because, while data exist on men's and women's formal employment, less information is available on informal work, seasonal work, and work carried out in the home, much of which is carried out by women and constitutes a substantial proportion of women's labor.

Our research reveals a need for fresh data to uncover hidden facets of the parent-child link and family life in general. One of our main goals is to promote a family-centered research and policy process that can provide an empirical counterpoint to the deafening rhetoric on "family values." Thus, in Chapter 5, we consider family policy - what it means and how it can support and strengthen the bonds between parents and children, particularly in relation to the basic questions: Who pays for the kids? Who cares for the kids?

No policy can be effective if it fails to address the realities of contemporary family life, especially marital, childbearing, and childrearing patterns. Yet governments and nongovernmental agencies have been slow to recognize the changing nature of families with children, thereby increasing the burdens of motherhood and perpetuating the neglect of fatherhood. We hope our work will provoke readers to reconsider the traditional, often rigid, assumptions about mothers, fathers, and children that underpin so many national and international policies. The parent-child relationship is the fundamental building block of human society; if it is broken under the assault of misguided policies, little else will be left to lose. 


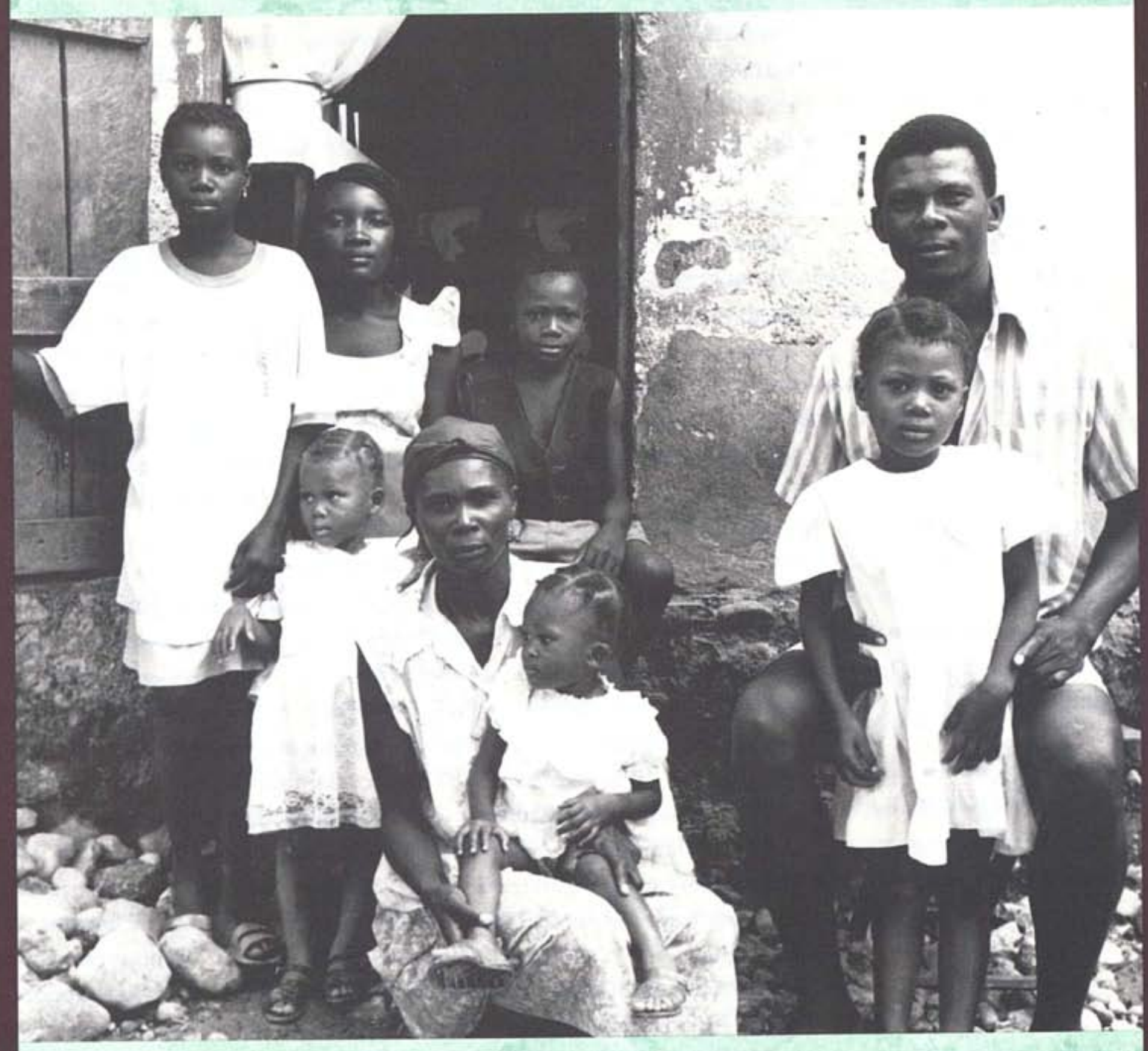




\section{H A P T ER O N E}

\section{Families in Transition}

Cynthia B. Lloyd and Niev Duffy

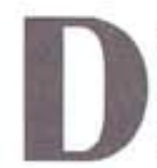

espite the dearth of data on families, five global trends in family formation, structure, and function can be inferred from the research record of the last two decades: 1) women's average age at first marriage and childbirth has risen, delaying the formation of new families; 2) families and households have gotten smaller; 3 ) the burden on working-age parents of supporting younger and older dependents has increased; 4) the proportion of female-headed households has increased; and 5) women's participation in the formal labor market has increased at the same time that men's has declined, shifting the balance of economic responsibility in families.

These trends are not evident everywhere, nor do they tell the whole story of modern family life. They do reveal some of the forces that are shaping the experience of many mothers, fathers, and children in the world today and suggest ways in which family aspirations and survival strategies are changing. This chapter presents the evidence for these trends, analyzes their causes, and investigates their implications for family life.

\section{Later marriage and childbirth}

Marriage and/or childbirth marks the beginning of a new family. Though a fundamental rite of passage in all societies, marriage varies greatly in form and function among cultures. Its commencement may be marked by religious rituals, a formal civil ceremony, the payment of a dowry or brideprice, the signing of a contract between elders, sexual intercourse between the betrothed, the abduction of a woman from her parents' household, or the birth of a child. It may begin lavishly with public celebrations or quietly as a young girl moves her few belongings into her husband's parental home, a widow and widower 
"Decreasing family

size can be

inferred from

declining fertility

rates and rising

age at first child-

birth in much of

the world." agree to live together, or a couple decide to "legitimize" a pregnancy or children already born.

Women's average age at first marriage varies greatly by region. In Bangladesh, Côte d'Ivoire, Ethiopia, Mali, and Nepal, at least half of all girls aged 15 to 19 were ever-married in the 1980 s. By contrast, in some Asian and Latin American countries, fewer than 10 percent, and as few as one percent, of girls of the same age were currently married at that time. ${ }^{1}$ In developed countries the proportion of women younger than 20 who are married is generally under 5 percent.

Underlying this conjugal diversity is a common thread: While marriage remains a popular institution everywhere - the proportion of women who have ever married by age 50 exceeds 90 percent in all but a few countries ${ }^{2}$ women's average age at first marriage is rising throughout the world. Between the 1970s and 1980s the proportion of women between the ages of 20 and 24 who had never married rose dramatically in a wide range of countries, increasing by 25 percent or more in Austria, the Dominican Republic, Mexico, and the United States; at least 50 percent in Kenya and Senegal; and 80 percent in Indonesia and Pakistan, for example (see Table 1).

Postponement of marriage usually coincides with postponement of childbearing. Thus, women's average age at first childbirth has increased in most developed and less developed countries over the last 20 years. Though the proportion of adolescent women giving birth is generally declining, it remains high (see Table 2). This is particularly true in sub-Saharan Africa: In Ghana, Kenya, and Senegal, for example, half or more of all first births are to women aged 20 and under. In Ecuador and Indonesia close to half of all first births are to adolescents.

\section{Smaller families and households}

Decreasing family size can be inferred from declining fertility rates and rising age at first childbirth in much of the world. In most developed countries in North America and Europe and a few in Asia (e.g., Hong Kong, Japan, Korea, Singapore, and Taiwan) fertility has fallen to replacement rates. In Germany, Italy, Spain, and many of the countries of Eastern Europe and the former Soviet Union, fertility has fallen to well below replacement rates. In less developed countries the situation is more diverse. In much of sub-Saharan Africa and the Middle East fertility rates remain high — five to seven children per woman on average - and large families continue to be the norm. However, in some countries in these regions, and in other less developed countries as well, the percent of ever-married women aged $40-44$ who have five or more 
TABLE I

Trends in percent of women aged 20-24 who have never been married (illustrative data)

\begin{tabular}{|c|c|c|c|c|}
\hline $\begin{array}{l}\text { REGION/ } \\
\text { COUNTRY }\end{array}$ & $\begin{array}{l}\text { EARLIER } \\
\text { DATE }\end{array}$ & PERCENT & $\begin{array}{l}\text { LATER } \\
\text { DATE }\end{array}$ & PERCENT \\
\hline \multicolumn{5}{|c|}{ Less DeVeloped COUNTRIES } \\
\hline \multicolumn{5}{|l|}{ Asia } \\
\hline Indonesia & 1976 & 20 & 1987 & 36 \\
\hline Pakistan & 1975 & 22 & $1990 / 91$ & 39 \\
\hline Sri Lanka & 1975 & 61 & 1987 & 58 \\
\hline Thailand & 1975 & 42 & 1987 & 48 \\
\hline \multicolumn{5}{|l|}{ Latin America/Caribbean } \\
\hline Colombia & 1976 & 44 & 1986 & 39 \\
\hline Dominican Republic & 1975 & 27 & 1986 & 39 \\
\hline Ecuador & 1979 & 43 & 1987 & 41 \\
\hline Mexico & 1976 & 34 & 1987 & 42 \\
\hline Peru & 1978 & 49 & 1986 & 56 \\
\hline \multicolumn{5}{|l|}{ Middle East/North Africa } \\
\hline Egypt & 1980 & 36 & 1989 & 40 \\
\hline Morocco & 1980 & 36 & 1987 & 56 \\
\hline Tunisia & 1978 & 57 & 1988 & 64 \\
\hline \multicolumn{5}{|l|}{ Sub-Saharan Africa } \\
\hline Ghana & 1980 & 15 & 1988 & 23 \\
\hline Kenya & 1978 & 21 & 1989 & 32 \\
\hline Senegal & 1978 & 14 & 1986 & 23 \\
\hline \multicolumn{5}{|c|}{ DeVEloped COUNTRIES } \\
\hline Austria & 1971 & 45 & 1980 & 57 \\
\hline Czechoslovakia & 1970 & 35 & 1980 & 33 \\
\hline France & 1970 & 46 & 1980 & 52 \\
\hline Spain & 1970 & 68 & 1981 & 59 \\
\hline United States & 1970 & 36 & 1980 & 51 \\
\hline
\end{tabular}

SOURCES: LeSS DEVEL LPED COUNTRIES - United Nations. 1987. Table 43 in Fertility Behaviour in the Context of Developmenr: Evidence from the World Fertility Survey New York: United Nations; and Westoff, Charles F., Ann K. Blanc, and Laura Nyblade. 1994. Marriage and Entry into Parenthood. Demographic and Health Surveys Comparative Studies no. 10. Calverton, Maryland: Macro International Inc. DEVELOPED COUNTRIES - Compiled by the United Nations Statistical Division for: United Nations. 1995. The World's Women 1970-1995: Trends and Statistics. New York: United Nations. 
TABLE 2

Trends in age of mother at first birth (illustrative data)

Median Age of Mother at First Birth in Given Age Groups in Less Developed Countries

\begin{tabular}{|c|c|c|c|}
\hline REGION/COUNTRY & $45-49$ & $35-39$ & $25-29$ \\
\hline \multicolumn{4}{|l|}{ Asia } \\
\hline Indonesia & 20.1 & 19.9 & 20.4 \\
\hline Pakistan & 22.6 & 21.4 & 21.0 \\
\hline Sri Lanka & 21.9 & 24.9 & 24.7 \\
\hline Thailand & 21.6 & 22.3 & 23.0 \\
\hline \multicolumn{4}{|l|}{ Latin America/Caribbean } \\
\hline Colombia & 20.9 & 21.5 & 21.5 \\
\hline Dominican Republic & 19.7 & 20.4 & 21.7 \\
\hline Ecuador & 21.6 & 21.2 & 20.7 \\
\hline Peru & 21.7 & 21.6 & 22.2 \\
\hline \multicolumn{4}{|c|}{ Middle East/North Africa } \\
\hline Egypt & 20.0 & 20.5 & 21.7 \\
\hline Morocco & 20.4 & 21.7 & 24.9 \\
\hline Tunisia & 22.4 & 22.5 & 24.5 \\
\hline \multicolumn{4}{|l|}{ Sub-Saharan Africa } \\
\hline Ghana & 19.3 & 19.5 & 20.0 \\
\hline Kenya & 19.7 & 18.6 & 18.6 \\
\hline Senegal & 19.2 & 18.7 & 19.0 \\
\hline
\end{tabular}

Mean Age of All Women Having a First Birth in Given Year in DeVELOPED COUNTRIES

\begin{tabular}{llll} 
COUNTRY & 1970 & 1980 & 1990 \\
\hline Austria & 23.7 & 24.3 & 26.1 \\
Czechoslovakia & 22.1 & 22.7 & $22.5^{\mathrm{a}}$ \\
Poland & 22.5 & 23.0 & 23.0 \\
Spain & $24.5^{\mathrm{b}}$ & 24.6 & $25.4^{\mathrm{c}}$ \\
Sweden & $24.5^{\mathrm{b}}$ & 25.5 & 26.3 \\
(former) West Germany & 24.3 & 25.2 & 26.9
\end{tabular}

$\begin{array}{lll}\text { a } 1989 & \text { b } 1975 & \text { c } 1987\end{array}$

SOURCES: Less Developed Countries - Westoff, Charles F., Ann K. Blanc, and Laura Nyblade. 1994. Marriage and Entry into Parenthood. Demographic and Health Surveys Comparative Studies no. 10. Calverton, Maryland: Macro International Inc. DEVELoped COUNTRIES - Council of Europe. 1993. Table T3.4 in Recent Demographic Developments in Europe and North America: 1992. Strasbourg: Council of Europe Press. 
TABLE 3

Trends in percent of ever-married women aged 40-44 with five or more living children in less developed countries (illustrative data)

\begin{tabular}{lllll}
\hline $\begin{array}{l}\text { REGION/ } \\
\text { COUNTRY }\end{array}$ & $\begin{array}{c}\text { EARLIER } \\
\text { DATE }\end{array}$ & PERCENT & $\begin{array}{c}\text { LATER } \\
\text { DATE }\end{array}$ & PERCENT \\
\hline Asia & 1976 & 43.5 & 1987 & 68.8 \\
\hline $\begin{array}{l}\text { Indonesia } \\
\text { Thailand }\end{array}$ & 1975 & 58.7 & 1987 & 31.8 \\
\hline $\begin{array}{l}\text { Latin America/Caribbean } \\
\text { Colombia }\end{array}$ & 1976 & 63.1 & 1986 & 48.7 \\
$\begin{array}{l}\text { Dominican Republic } \\
\text { Peru }\end{array}$ & 1975 & 56.6 & 1986 & 51.2 \\
$\begin{array}{l}\text { Middle East/North Africa } \\
\text { Egypt }\end{array}$ & 1978 & 58.8 & 1986 & 54.4 \\
$\quad$ Morocco & 1980 & 55.2 & 1989 & 49.5 \\
\hline $\begin{array}{l}\text { Sub-Saharan Africa } \\
\text { Ghana }\end{array}$ & 1980 & 68.9 & 1987 & 68.8 \\
Kenya & 1980 & 60.9 & 1988 & 68.9 \\
\hline
\end{tabular}

SOURCES: Tabulations from Demographic and Health Surveys standard recodes; and World Fertility Surveys: IndONESIA - Indonesia Fertility Survey 1976: Principal Report. Vols. I and II: Statistical Tables. 1978. Thalland - The Survey of Fertility in Thailand: Country Report. Vol. II. 1977. Colombia Encuesta Nacional de Fecundidad Colombia 1976: Resultados Generales. 1977. DominiCan RePUBLIC Encuesta Nacional de Fecundidad: Informe General. 1976. PERU - Encuesta Nacional de Fecundidad del Peru 1977-1978. 1979. Egrpt - The Egyptian Fertility Survey 1980. Vol. IV: Statistical Tables. 1983. Morocco - Enquête Nationale sur la Fécondité et la Planification Familiale au Maroc 1979 - 80: Rapport National. Vol. IV: Tableaux Statistiques: Caractéristiques Démographiques. 1984. GHANA - Ghana Fertility Survey 1979-80. Vol. II: Statistical Tables. 1983. KenYA - Kenya Fertility Survey 1977-1978. Vol. II. 1980.

living children has fallen: For example, the proportion of such women fell by more than 20 percent in Colombia and more than 45 percent in Thailand over a recent 10-to-12-year period (see Table 3). In Latin America and Southeast Asia fertility rates have declined markedly. In some less developed countries (e.g., Argentina, Chile, China, Indonesia, and Sri Lanka) fertility rates have fallen below three children per woman, reducing the prevalence of large families.

In a few less developed countries where fertility rates have declined but infant mortality rates have declined more rapidly, average numbers of surviving children per family have remained constant or even risen slightly (see Table 4). For example, average numbers of surviving children have remained 
TABLE 4

Trends in numbers of children ever born and surviving children for women aged $40-44$ in less developed countries (illustrative data)

\begin{tabular}{|c|c|c|c|c|c|c|}
\hline $\begin{array}{l}\text { REGION/ } \\
\text { COUNTRY }\end{array}$ & $\begin{array}{c}\text { EARLIER } \\
\text { DATE }\end{array}$ & $\begin{array}{c}\text { CHILDREN } \\
\text { BORN } \\
\text { (average na.) }\end{array}$ & $\begin{array}{l}\text { CHILDREN } \\
\text { SURVIVING } \\
\text { (average no.) }\end{array}$ & $\begin{array}{l}\text { LATER } \\
\text { DATE }\end{array}$ & $\begin{array}{c}\text { CHILDREN } \\
\text { BORN } \\
\text { (average no.) }\end{array}$ & $\begin{array}{l}\text { CHILDREN } \\
\text { SURVIVING } \\
\text { (average no.) }\end{array}$ \\
\hline \multicolumn{7}{|l|}{ Asia } \\
\hline Indonesia & 1976 & 5.3 & 4.1 & 1987 & 5.2 & 4.3 \\
\hline Sri Lanka & 1975 & 5.3 & 4.7 & 1987 & 4.0 & 3.7 \\
\hline Thailand & 1975 & 5.8 & 4.9 & 1987 & 3.9 & 3.5 \\
\hline \multicolumn{7}{|l|}{ Latin America/Caribbean } \\
\hline Colombia & 1976 & 6.1 & 5.2 & 1986 & 4.9 & 4.4 \\
\hline Dominican Republic & 1975 & 6.4 & 5.4 & 1986 & 5.5 & 4.8 \\
\hline Ecuador & 1979 & 6.4 & 5.3 & 1987 & 5.4 & 4.7 \\
\hline Mexico & 1976 & 6.6 & 5.7 & 1987 & 5.4 & 4.9 \\
\hline Peru & 1978 & 6.3 & 4.9 & 1986 & 5.7 & 4.8 \\
\hline
\end{tabular}

Middle East/North Africa

$\begin{array}{lllllll}\text { Egypt } & 1980 & 6.3 & 5.8 & 1989 & 5.8 & 4.6 \\ \text { Morocco } & 1980 & 7.1 & 5.6 & 1987 & 6.7 & 5.6 \\ \text { Tunisia } & 1978 & 6.5 & 5.3 & 1988 & 5.5 & 4.8\end{array}$

Sub-Saharan Africa

$\begin{array}{lllllll}\text { Ghana } & 1980 & 6.1 & 5.1 & 1988 & 6.6 & 5.4 \\ \text { Kenya } & 1978 & 7.6 & 6.1 & 1989 & 7.4 & 6.5\end{array}$

SOURCES: Arnold, Fred and Ann K. Blanc. 1990. Fertility Levels and Trends. Demographic and Health Surveys Comparative Studies no. 2. Columbia, Maryland: Institute for Resource Development; and United Nations. 1987. Fertility Behaviour in the Context of Development: Evidence from the World Fertility Surveg. New York: United Nations. 
TABLE 5

Trends in average household size in developed countries (illustrative data)

\begin{tabular}{|c|c|c|c|c|c|c|}
\hline \multirow[b]{2}{*}{ COUNTRY } & \multicolumn{3}{|c|}{$\begin{array}{l}\text { AVERAGE HOUSEHOLD SIZE } \\
\text { (no. of members) }\end{array}$} & \multicolumn{3}{|c|}{$\begin{array}{l}\text { HOUSEHOLDS WITH I MEMBER } \\
\text { (\% of all households) }\end{array}$} \\
\hline & c. 1970 & c. 1980 & c. 1990 & c. 1970 & c. 1980 & c. 1990 \\
\hline Australia & 3.3 & 3.0 & u & 13.5 & 20.0 & u \\
\hline Austria & 2.9 & 2.7 & $\mathrm{u}$ & 24.6 & 28.3 & $\mathrm{u}$ \\
\hline Canada & 3.5 & 2.9 & $2.8^{a}$ & 13.4 & 20.3 & $21.5^{\mathrm{a}}$ \\
\hline Czechoslovakia & 3.1 & 2.8 & u & 17.9 & 22.0 & $\mathrm{u}$ \\
\hline Japan & 3.7 & 3.2 & 3.0 & 13.2 & 19.8 & 23.1 \\
\hline Poland & 3.4 & 3.1 & u & 16.1 & 17.4 & 18.3 \\
\hline Spain & 3.8 & 3.5 & $\mathrm{u}$ & 8.0 & 10.2 & u \\
\hline Sweden & 2.6 & 2.3 & $2.2^{\mathrm{b}}$ & 25.3 & 32.8 & $36.1^{b}$ \\
\hline United States & 3.1 & 2.7 & 2.6 & 17.6 & 22.7 & 24.6 \\
\hline (former) USSR & 3.7 & 4.0 & 3.0 & u & $\mathrm{u}$ & 18.3 \\
\hline (former) West Germany & 2.7 & 2.4 & $2.3^{\mathrm{c}}$ & 25.1 & u & $33.4^{\mathrm{c}}$ \\
\hline =unavailable & & 1985 & c 1987 & & & \\
\hline
\end{tabular}

SOURCE: United Nations. Forthcoming. Tables 1 and 3 in Living Arrangements of Women and Their Children in the Third World: A Demographic Profile. New York: United Nations.

fairly constant in Morocco and Peru, and have increased in Indonesia and Kenya, despite declining fertility rates in all these countries. Average numbers of surviving children typically decline once parents adjust fertility downward to compensate for continuing declines in infant and child mortality.

Survey and census data provide direct evidence of decreasing average household size in most regions of the world. Between the early 1970s and early 1980 s average household size fell by almost 10 percent in a wide range of developed and less developed countries (see Tables 5 and 6). In developed countries this trend reflects an increase in single-person households, especially among elderly persons and unmarried adults (see Table 5). In less developed countries the trend corresponds to a sharp decline in the proportion of households with five or more members (see Table 6).

Household size often corresponds to family size, but this is not always the case. Family members may disperse, reducing the size of the household but not the family. Dispersal of family members is, of course, intrinsic to the 
TABLE 6

Trends in household size in less developed countries (illustrative data)

\begin{tabular}{|c|c|c|c|c|c|c|}
\hline \multirow[b]{2}{*}{ REGION/COUNTRY } & \multicolumn{3}{|c|}{$\begin{array}{l}\text { AVERAGE HOUSEHOLD SIZE } \\
\text { (no. of members) }\end{array}$} & \multicolumn{3}{|c|}{$\begin{array}{l}\text { HOUSEHOLDS WITH } 5 \text { OR MORE MEMBERS } \\
\text { ( } \% \text { of all households })\end{array}$} \\
\hline & c. 1970 & c. 1980 & c. 1987 & c. 1970 & c. 1980 & c. 1987 \\
\hline \multicolumn{7}{|l|}{ Asia } \\
\hline Korea & 5.2 & 4.5 & 4.1 & $59.1^{\mathrm{a}}$ & 49.9 & 39.0 \\
\hline Nepal & 5.5 & 5.8 & $\mathbf{u}$ & 59.6 & 64.2 & $\mathrm{u}$ \\
\hline Philippines & 5.9 & 5.6 & $\mathrm{u}$ & 66.4 & $65.5^{a}$ & $\mathbf{u}$ \\
\hline Thailand & 5.7 & 5.2 & 4.6 & 65.1 & 57.8 & 47.1 \\
\hline \multicolumn{7}{|l|}{ Latin America/Caribbean } \\
\hline Brazil & 5.1 & 4.4 & $\mathrm{u}$ & 52.2 & 40.8 & $\mathrm{u}$ \\
\hline Chile & 5.1 & 4.5 & $\mathrm{u}$ & 53.7 & 44.3 & $\mathrm{u}$ \\
\hline Cuba & 4.5 & 4.1 & $\mathbf{u}$ & 42.2 & 36.3 & $\mathrm{u}$ \\
\hline Mexico & 4.9 & 5.5 & $\mathrm{u}$ & 49.9 & 57.6 & $\mathrm{u}$ \\
\hline Peru & 4.8 & 4.9 & 5.1 & 50.2 & 51.4 & 56.1 \\
\hline Trinidad and Tobago & 4.8 & 4.5 & 4.2 & 47.5 & 43.6 & 41.5 \\
\hline \multicolumn{7}{|l|}{ Sub-Saharan Africa } \\
\hline Botswana & 4.5 & 5.4 & 4.8 & $\mathbf{u}$ & 53.8 & 46.5 \\
\hline Mali & $\mathrm{u}$ & $5.5^{b}$ & 5.0 & $\mathrm{u}$ & 48.4 & 47.6 \\
\hline Zambia & 4.6 & 5.0 & $\mathrm{u}$ & 44.4 & 43.3 & $\mathrm{u}$ \\
\hline \multicolumn{7}{|l|}{ West Asia/North Africa } \\
\hline Egypt & $\mathrm{u}$ & $5.2^{b}$ & 5.5 & $\mathrm{u}$ & $56.9^{b}$ & 61.2 \\
\hline Morocco & 5.4 & 5.9 & 6.0 & 57.6 & 62.9 & 65.2 \\
\hline Turkey & 6.6 & 5.2 & 5.2 & 63.3 & $60.0^{a}$ & 54.0 \\
\hline t=unavailable & 975 & b 1976 & & & & \\
\hline
\end{tabular}

SOURCE: United Nations. Forthcoming. Tables 1 and 3 in Living Arrangements of Women and Their Children in the Third World: A Demographic Profile. New York: United Nations. 
"Survey and census

data provide

direct evidence of

decreasing average

bousehold size in

most regions of

the world." natural history of households: Households grow larger when children are born or aging parents move in, then shrink again when elderly parents die and grown children leave to start their own households. In many countries young people marry and begin childbearing while still living in their parents' households, then leave when custom dictates or economic conditions and housing availability permit a move.

There is some evidence that, beyond this natural ebb and flow of family members, families throughout the world are becoming more dispersed. Young and elderly adults, spouses, and other relatives who might otherwise have shared a home are now more likely to live apart from one another.

In less developed regions the principal forces of family dispersal are labor migration and refugee movements caused by war, famine, disease, environmental degradation, or political unrest. The estimated number of refugees in the world increased from 2.5 million in 1970 to 18.2 million in 1993, with an additional 24 million people internally displaced in 1993 (a conservative estimate). This means that "roughly one in every 130 people on earth has been forced into flight," the United Nations High Commissioner for Refugees wrote $^{3}$ - before the mass exodus of refugees from Rwanda in 1994. Labor migration is also widespread. Family members may be pulled by economic opportunities or pushed by economic hardship to migrate from rural areas to cities or other employment sites within their country or across country borders. Population growth and stagnation in rural economies can lead to heavy migrant outflows to urban areas. The economic rewards for labor migration can be substantial - total remittances from migrants were estimated to be $\$ 71$ billion in $1990^{4}$ - creating a strong incentive to migrate. More and more people's livelihoods have come to depend on easy mobility within their country involving day-long, week-long, or month-long absences from home.

As average family size shrinks, the rhythms of family life change. Within a generation or two a large, extended family may become quite small, resulting in fewer kin at family gatherings and fewer family births, marriages, and deaths. Children have fewer siblings and cousins for playmates than their parents did. Parents spend longer periods of time living together without children at home, both during their reproductive years and after their children have grown.

Maintaining ties among separated family members can be difficult and can spell the difference between subsistence and destitution. With fewer aunts and uncles to help tend to young children, and fewer children to support aging parents, dependent family members may be less likely to receive adequate care. Identifying vulnerable individuals who lack family support requires detailed data on financial and emotional relationships within house- 
holds and families. Because such data are rare, we are unable to answer many pressing questions about the effects of family dispersal on family relationships.

\section{Increasing dependency burden on working-age parents}

The reduction or loss of extended kinship support networks forces workingage parents to assume greater responsibility for the care and support of younger and older dependent family members. This dependency burden is intensified by the rising cost of supporting elderly parents and raising children. Under these circumstances the sustained commitment of each workingage parent to the support of dependents becomes more critical than ever.

Increased life expectancy in most countries has extended the period of time during which working-age adults must support elderly parents. ${ }^{5}$ The ratio of older people ( 65 and over) to working-age adults increased an average of 21 percent in developed countries and 6 percent in less developed countries between 1970 and 1990. This ratio is projected to continue to increase over the next 20 years, growing by 23 percent in developed countries and by 18 percent in less developed countries. ${ }^{6}$

Though many couples today have fewer children than their parents did, their total economic investment in children is greater because of increased investments in children's education and rising school-related costs. Parents' motivation to educate their children has increased with growing competition for jobs, changing values, and modernizing economies; the result is a rapid rise in educational enrollment at all levels. ${ }^{7}$ Educating children increases household expenditures on school fees, transportation, uniforms, and supplies. The opportunity cost of a child's foregone wages and labor while he/she is in school, especially at the secondary and tertiary levels, is the greatest schoolrelated expense for families in which children's economic contributions are critical to family survival.

School costs have also increased in some places as a result of cuts in public funding for education. Debt-reduction policies adopted in many developed and less developed countries between 1972 and 1989 led to significant declines in the share of government expenditures allocated to education. ${ }^{8}$ Such policies shift a larger portion of education expenses to parents, increasing the overall cost to parents of preparing their children for adulthood.

\section{Increasing proportion of female-headed households}

The first study of female-headed households, conducted after the World Conference of the International Women's Year in 1975, reported that 10-46 percent of women over the age of 20 in 19 less developed countries could be labeled "head of household" on the basis of data on divorce, separation, wid- 
“...recent data

reveal a rapidly

rising proportion

of fermale-headed

households in

both developed

and less developed

countries." owhood, and single parenthood in these countries.' More recent data reveal a rapidly rising proportion of female-headed households in both developed and less developed countries. In less developed countries and Japan direct evidence for this trend comes from data on female household headship (see Table 7); in developed countries indirect evidence comes from data on singleparent households (defined as households with dependent children and one resident parent), in the vast majority of which the single parent is the moth$\mathrm{er}^{10}$ (see Table 8). Adequate data are lacking on single-parent households in less developed countries, but we can assume that their proportions are increasing as well, given that mother-headed households represent a substantial proportion of all female-headed households. ${ }^{11}$

Local initiatives in less developed countries reflect an emerging concern with single parenthood. In Southern Africa, for example, the Women and Law in Southern Africa Trust, a network of professional women, is conducting in-depth studies of the legal, social, and economic situation of married and unmarried mothers seeking child support and of the ability of widows (many of whom have dependent children) to inherit from their deceased husbands. ${ }^{12}$

A variety of demographic, social, and economic factors contribute to the high and growing proportions of female-headed and single-parent households. These include increasing levels of migration and high, and in some places increasing, levels of marital dissolution and nonmarital childbearing (see Chapter 2 for related discussion).

Marital dissolution. Marital dissolution through abandonment, separation, divorce, or death of a spouse is common throughout the world. A recent review of global divorce patterns reported that a growing proportion of divorces involve couples with young children, ${ }^{13}$ increasing the likelihood that marital dissolution will lead to single parenthood.

Marital dissolution is common in many less developed countries in subSaharan Africa, the Middle East, and Asia. About 40-60 percent of women in their forties in the Dominican Republic, Ghana, Indonesia, and Senegal reported in recent Demographic and Health Surveys that their first marriage had dissolved, as did at least 25 percent of women in most other countries surveyed (see Table 9).

Data indicate a trend toward increasing divorce rates in developed countries (see Table 10). Though rates vary widely — from eight divorces per 100 marriages in Italy to 55 per 100 in the United States in 1990 - rates have increased in every country, more than doubling in Canada, France, Greece, the Netherlands, the United Kingdom, and former West Germany between 1970 and 1990. 
TABLE 7

Trends in percent of households headed by women de jure (all available data)

\begin{tabular}{|c|c|c|c|c|}
\hline $\begin{array}{l}\text { REGION/ } \\
\text { COUNTRY }\end{array}$ & $\begin{array}{l}\text { EARLIER } \\
\text { DATE }\end{array}$ & PERCENT & $\begin{array}{l}\text { LATER } \\
\text { DATE }\end{array}$ & PERCENT \\
\hline \multicolumn{5}{|c|}{ DEMOGRAPHIC SURVEY DATA } \\
\hline \multicolumn{5}{|l|}{ Asia } \\
\hline Indonesia & 1976 & 15.5 & 1987 & 13.6 \\
\hline Sri Lanka & 1975 & 15.7 & 1987 & 17.8 \\
\hline Thailand & 1975 & 12.5 & 1987 & 20.8 \\
\hline \multicolumn{5}{|l|}{ Latin America/Caribbean } \\
\hline Colombia & 1976 & 17.5 & 1986 & 18.4 \\
\hline Dominican Republic & 1975 & 20.7 & 1986 & 25.7 \\
\hline Ecuador & 1979 & 15.0 & 1987 & 14.6 \\
\hline Mexico & 1976 & 13.5 & 1987 & 13.3 \\
\hline Peru ${ }^{a}$ & $1977 / 78$ & 14.7 & 1986 & 19.5 \\
\hline Trinidad and Tobago & 1977 & 22.6 & 1987 & 28.6 \\
\hline \multicolumn{5}{|c|}{ Middle East/North Africa } \\
\hline Morocco & $1979 / 80$ & 11.5 & 1987 & 17.3 \\
\hline \multicolumn{5}{|l|}{ Sub-Saharan Africa } \\
\hline Ghana & 1960 & 22.0 & 1987 & 29.0 \\
\hline Sudan & $1978 / 79$ & 16.7 & $1989 / 90$ & 12.6 \\
\hline
\end{tabular}


TABLE 7 (continued)

\begin{tabular}{lcccc}
\hline $\begin{array}{l}\text { REGION } \\
\text { COUNTRY }\end{array}$ & $\begin{array}{c}\text { EARLIER } \\
\text { DATE }\end{array}$ & PERCENT & $\begin{array}{c}\text { LATER } \\
\text { DATE }\end{array}$ & PERCENT \\
\hline CENSUS DATA & & \\
\hline Asia & & & & \\
\hline Hong Kong & 1971 & 23.5 & 1991 & 25.7 \\
\hline Indonesia & 1971 & 16.3 & 1980 & 14.2 \\
\hline Japan & 1980 & 15.2 & 1990 & 17.0 \\
\hline Korea & 1980 & 14.7 & 1990 & 15.7 \\
\hline Philippines & 1970 & 10.8 & 1990 & 11.3 \\
\hline Latin America/Caribbean & & & & \\
\hline Brazil & 1980 & 14.4 & 1989 & 20.1 \\
\hline Costa Rica & 1984 & 17.5 & 1992 & 20.0 \\
\hline Panama & 1980 & 21.5 & 1990 & 22.3 \\
\hline Peru & 1981 & 22.1 & 1991 & 17.3 \\
\hline Uruguay & 1975 & 21.0 & 1985 & 23.0 \\
\hline Venezuela & 1981 & 21.8 & 1990 & 21.3 \\
\hline Sub-Saharan Africa & 1975 & 5.1 & 1985 & 9.7 \\
\hline Burkina Faso & & 13.8 & 1987 & 18.5 \\
\hline Cameroon & 1976 & 15.1 & 1987 & 14.0 \\
\hline Mali & & & & \\
\hline
\end{tabular}

NOTE: de jure = "usual" household headship

a de facto $=$ headship on day of interview

SOURCES: Demographic Surveys - Ghana: Lloyd, Cynthia B, and Anastasia J. Gage-Brandon. 1993. "Women's role in maintaining houscholds: Family welfare and sexual inequality in Ghana," Population Studies 47(1):115-131. Ecuador: Ono-Osaku, Keiko and A.R. Themme, "Cooperative analysis of recent changes in households in Latin America" in IUSSP Proceedings of Conference on the Americas, Vera Cruz. 1993. All other countries: Ayad, Mohamed, et al. 1994. Demographic Charatteristics of Houscholds. Demographic and Health Surveys Comparative Studies no. 14. Calverton, Maryland: Macro International Inc. Censuses - United Nations. 1995. The World's Women 1970-1995: Trends and Statistics. New York: United Nations. 


\section{TABLE 8}

Trends in single-parent households as a percent of all households with dependent children and at least one resident parent in developed countries (illustrative data)

\begin{tabular}{lcc}
\hline COUNTRY & EARLY 1970s & MID-1980s \\
\hline Australia & 9.2 & 14.9 \\
\hline France & 9.5 & 10.2 \\
\hline Japan & 3.6 & 4.1 \\
\hline Sweden & 15.0 & 17.0 \\
\hline United Kingdom & 8.0 & 14.3 \\
\hline United States & 13.0 & 23.9 \\
\hline (former) USSR & 10.0 & 20.0 \\
\hline (former) West Germany & 8.0 & 11.4 \\
\hline
\end{tabular}

NOTE: Single-parent households are households with dependent children and one resident parent. SOURCE: Burns, Ailsa. Spring 1992. "Mother-headed families: An international perspective and the case of Australia," Social Policy Report 6(1).

Accurately assessing global trends in marital dissolution is difficult because some unions dissolve through informal mechanisms, such as separation or abandonment. A few Latin American surveys are the only existing sources of data on informal marital dissolution; according to these surveys informal marriages (called consensual unions) are prevalent and dissolve more quickly than their legal counterparts in Latin America. ${ }^{14}$

Death of a spouse can result in single parenthood for women in less developed countries, where marital fertility continues late into the reproductive years and life expectancy is lower than in developed countries. In those less developed countries in which husbands are often substantially older than their wives - e.g., Bangladesh, Ghana, Morocco, Nigeria, and Sudan, where average spousal age differences range from seven to ten years ${ }^{15}$ - a significant proportion of women become widows when they have children under the age of 15 (for further discussion, see Chapter 2).

Nonmarital childbearing. Some single-parent households are headed by women who have given birth outside of marriage. Data on reproductive-age women (15-49) collected by the Demographic and Health Surveys between 1986 and 1992 indicate that a substantial proportion of never-married 
TABLE 9

Percent of first marriages dissolved through separation, divorce, or death among women aged $40-49$ in less developed countries (illustrative data)

\begin{tabular}{|c|c|c|}
\hline REGION/COUNTRY & DATE & PERCENT \\
\hline \multicolumn{3}{|l|}{ Asia } \\
\hline Indonesia & 1987 & 37.3 \\
\hline Sri Lanka & 1987 & 25.6 \\
\hline Thailand & 1987 & 24.8 \\
\hline \multicolumn{3}{|l|}{ Latin America/Caribbean } \\
\hline Colombia & 1986 & 32.5 \\
\hline Dominican Republic & 1986 & 49.5 \\
\hline Ecuador & 1987 & 28.9 \\
\hline Mexico & 1987 & 25.5 \\
\hline Peru & 1986 & 26.1 \\
\hline \multicolumn{3}{|l|}{ Middle East/North Africa } \\
\hline Egypt & 1989 & 22.8 \\
\hline Morocco & 1987 & 31.2 \\
\hline Tunisia & 1988 & 11.1 \\
\hline \multicolumn{3}{|l|}{ Sub-Saharan Africa } \\
\hline Ghana & 1988 & 60.8 \\
\hline Kenya & 1989 & 24.2 \\
\hline Senegal & 1986 & 42.3 \\
\hline Sudan & $1989 / 90$ & 28.2 \\
\hline
\end{tabular}

women have been, or are, sexually active. A notable proportion of these never-married women have given birth in some regions: more than 20 percent in seven countries in sub-Saharan Africa (Botswana, Cameroon, Kenya, Liberia, Madagascar, Namibia, and Tanzania) and 10 percent or more in three Latin American countries (Bolivia, Colombia, and Paraguay). ${ }^{16}$ In some countries the proportion of women who have had a premarital birth by the 
TABLE 10

Trends in divorce rates per 100 marriages in developed countries (illustrative data)

\begin{tabular}{|lccc}
\hline COUNTRY & 1970 & 1980 & 1990 \\
\hline Canada & 18.6 & 32.8 & 38.3 \\
\hline Czechoslovakia & 21.8 & 26.6 & $32.0^{\mathrm{a}}$ \\
\hline Denmark & 25.1 & 39.3 & 44.0 \\
\hline England and Wales & 16.2 & 39.3 & $41.7^{\mathrm{a}}$ \\
\hline France & 12.0 & 22.2 & $31.5^{\mathrm{a}}$ \\
\hline Greece & 5.0 & 10.0 & 12.0 \\
\hline Hungary & 25.0 & 29.4 & 31.0 \\
\hline Italy & 5.0 & 3.2 & 8.0 \\
\hline Netherlands & 11.0 & 25.7 & 28.1 \\
\hline Sweden & 23.4 & 42.2 & 44.1 \\
\hline United States & 42.3 & 58.9 & $54.8^{\mathrm{b}}$ \\
\hline (former) West Germany & 12.2 & 22.7 & 29.2 \\
\hline
\end{tabular}

NOTE: Rates shown in this table are a synthetic index calculated by summing duration-specific divorce rates in each year. (Original source incorrectly identifies rates as "per 1,000 marriages.")

a 1989 b 1985

SOURCE: Monnier, Alain and Catherine de Guibert-Lantoine. 1993. "La conjoncture démographique: L'Europe et les pays développés d'outre-mer," Population 48(4):1043-1067.

age of 20 is high: more than 20 percent in Kenya and Liberia and 43 percent in Botswana. The proportion of adolescent mothers giving birth outside of marriage has increased in some countries; in Botswana and Kenya this proportion has increased sharply. ${ }^{17}$

\section{Shifting balance of economic responsibility in families}

The economics of the family and the sexual division of labor within the family are very much determined by opportunities in the labor market. A review of trends in labor force participation rates in developed market economies reveals steady increases in the labor force participation of women over the last 
"Overall the data

suggest a global

trend toward an

increasing

proportion of

mother-supported

families."
20 years, which have been partially offset by declines in male participation rates. $^{18}$ Data from 15 Latin American countries show male labor force participation rates to be consistently lower in 1980 than in $1950 .{ }^{19}$ In the United States the proportion of men aged 22 to 58 working full-time year-round dropped from 80 to 70 percent between the 1970s and the $1980 \mathrm{~s}^{20}$

High female labor force participation rates have been associated with declines in male employment - e.g., in Canada, France, Sweden, and the United States - and/or increasing unemployment for women ${ }^{21}$ - e.g., in France, Italy, the Netherlands, and Spain. In all of these countries the percentage of prime-working-age men who are either unemployed or not in the labor force has increased. Most of these men are less-skilled workers; as a result, income inequality has increased in these countries. In the economies of Eastern Europe and the former Soviet Union, which are currently undergoing radical changes in their economic structures, unemployment has risen rapidly and the problems of generating adequate employment opportunities for men and women have been acute.

Both developed and less developed economies are witnessing a new phenomenon: "jobless growth." Growth in per-capita output has not been matched by growth in formal employment, with the result that informal employment, which is usually low-wage and less stable, has increased sharply in less developed economies. ${ }^{22}$ Furthermore, deregulation of labor markets has resulted in weakening income and employment security and the "feminization" of many jobs traditionally held by men. ${ }^{23}$ The declining ability of men to earn a "family wage," coupled with the growing need for cash for family maintenance in modernizing economies, has resulted in an increasing proportion of two-earner families in both developed and less developed countries. ${ }^{24}$

The trends described in this chapter serve as markers of important changes in the ways in which resources are acquired and distributed within families. Overall the data suggest a global trend toward an increasing proportion of mother-supported families - that is, families in which mothers are the primary or sole economic providers. Women's roles have evolved to accommodate these increased family responsibilities, but concomitant changes in public perceptions and policies have lagged behind. The next chapter discusses the neglected economic dimensions of motherhood and factors contributing to the formation of mother-supported families. 


\section{NOTES}

1. United Nations. 1990. Patterns of First Marriage: Timing and Prevalence. New York: United Nations.

2. Ibid.

3. United Nations High Commissioner for Refugees. 1993. The State of the World's Refugees: The Challenge of Protection. New York: Penguin Books.

4. Teitelbaum, Michael S. and Sharon Stanton Russell. 1994. "International migration, fertility, and development" in Robert Cassen et al., Population and Development: Old Debates, New Conclusions. Washington, D.C.: Overseas Development Council, pp. 229-252.

5. United Nations. Forthcoming. World Population Prospects: The 1994 Revision-Annex Tables. New York: United Nations.

6. Ibid.

7. UNESCO. 1992. Statistical Yearbook 1992. Paris: UNESCO.

8. World Bank. 1991. World Development Report. New York: Oxford University Press.

9. Buvinić, M., N. Youssef, and B. von Elm. 1978. "Women-headed households: The ignored factor in development planning." Washington, D.C.: International Center for Research on Women.

10. Kamerman, S. B. and J. J. Kahn. 1988. "What Europe does for single-parent families," Public Interest 93:70-86. Cited in Nancy Folbre. 1994. Who Pays for the Kids? Gender and the Structures of Constraint. London and New York: Routledge.

11. Lloyd, Cynthia B. and Sonalde Desai. 1992. "Children's living arrangements in developing countries," Population Research and Policy Review 11:193-216.

12. Armstrong, Alice K. 1992. "Women and maintenance in Southern Africa." Women and Law in Southern Africa Trust regional report. Harare, Zimbabwe: University of Zimbabwe Publications.

13. Goode, William J. 1993. World Changes in Divorce Patterns. New Haven: Yale University Press.

14. Ibid.

15. Casterline, John B., Lindy Williams, and Peter McDonald. 1986. "The age difference between spouses: Variations among developing countries," Population Studies 40:353-374.

16. Westoff, Charles F., Ann K. Blanc, and Laura Nyblade. 1994. Marriage and Entry into Parenthood. Demographic and Health Surveys Comparative Studies no. 10. Calverton, Maryland: Macro International Inc.

17. Bledsoe, Caroline H. and Barney Cohen (eds.). 1993. Social Dymamics of Adolescent Fertility in Sub-Saharan Africa. Washington, D.C.: National Academy Press.

18. United Nations. 1994. World Economic and Social Survey, 1994: Current Trends and Policies in the World Economy. New York: United Nations.

19. Psacharopoulos, George and Zafiris Tzannatos (eds.). 1992. Women's Employment and Pay in Latin America: Overview and Methodology. Washington, D.C.: The World Bank, p. 17.

20. This includes only men working eight out of the last ten years. Stephen J. Rose, National Commission for Employment Policy, cited by Sylvia Nasar, "More men in prime of life spend less time working," The New York Times, 1 December 1994. 
21. The labor force includes the employed and the unemployed, the latter defined as those actively seeking work. It excludes individuals who are not working by choice. Thus, labor force participation and unemployment can increase simultaneously.

22. United Nations Development Programme. 1993. Human Development Report 1993. New York: United Nations.

23. Standing, Guy. 1989. "Global feminization through flexible labor," World Development 17(7):1077-1095.

24. For a fuller discussion of these items, see Standing, Guy. "Global feminization through flexible labor revisited." Unpublished manuscript. 


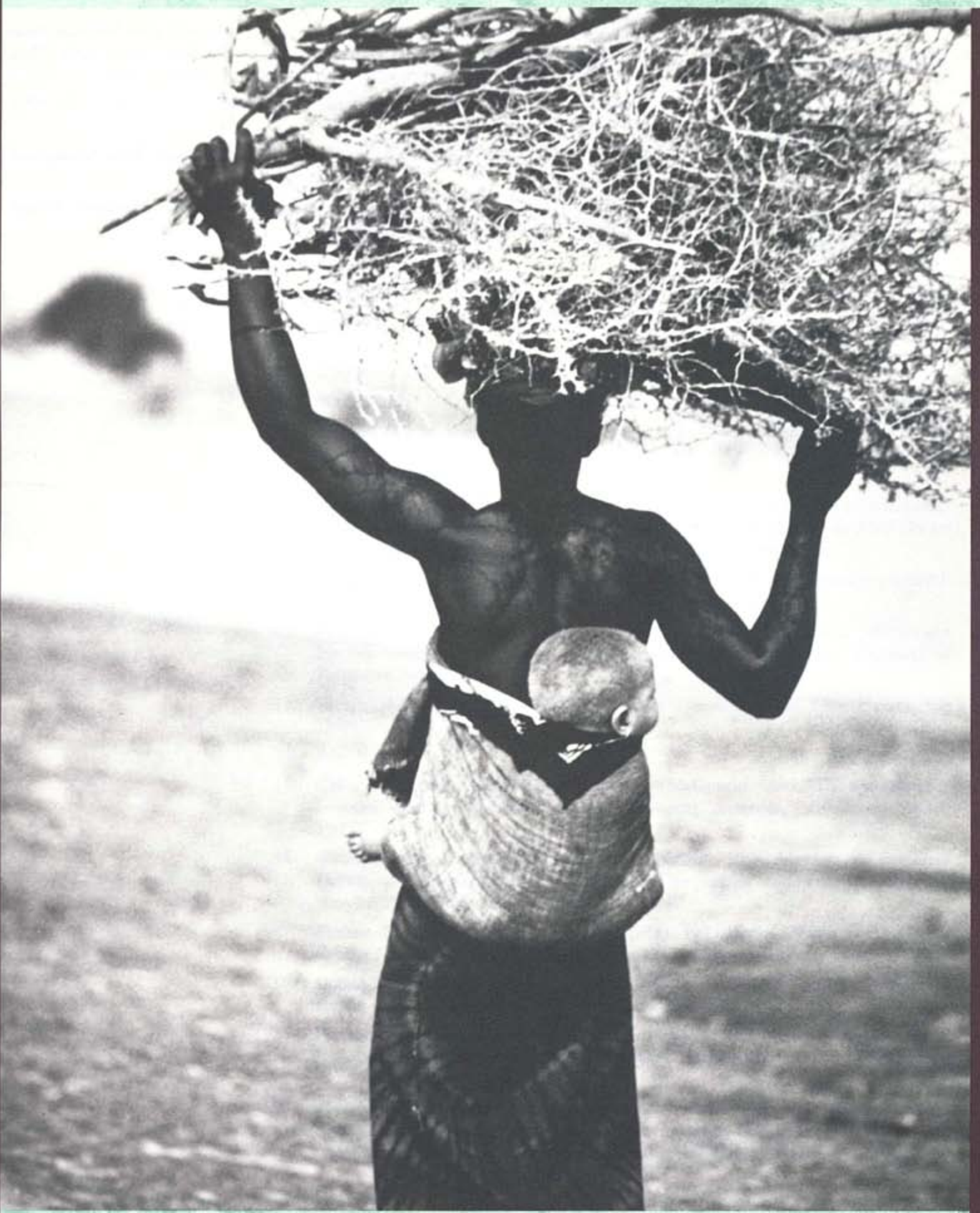




\section{CHAPTER T W O \\ The Economics of Motherhood}

\section{Judith Bruce}
cross cultures and throughout history women have been defined pri- marily as mothers. Indeed, most women do become sexually active, marry, and bear children, whether they welcome or fear the demands of motherhood.

Several decades of research and advocacy at local, national, and international levels have fostered public appreciation of women's roles apart from motherhood, including their contributions to society through wage-earning labor, political participation, creative and intellectual endeavors, and community service. Now a similar re-education is needed with respect to how motherhood itself is conceptualized and valued.

Contrary to myth, motherhood is not limited to bearing children and caring for family members (activities at once celebrated and vastly undervalued). Motherhood has always involved a number of other functions as well - notably providing economic support to dependent family members, especially children.

\section{Prevalence of mother-supported families}

Conventional economic policy in developed and less developed countries alike assumes that most families are headed by a fair-minded, male decisionmaker whose income is the central, if not only, economic resource for the fam- 
"...motherhood is

not limited to

bearing children

and caring for

family members...

(it) has always

involved...

providing

economic support

to dependent

family members,

especially

children." ily. In this schema women's income contributions to families are supplementary to the earnings of men, and women's unpaid labor is of limited economic value to families.

These assumptions are belied by the everyday experience of people everywhere. They are also challenged by an abundance of evidence that there is a high, and probably growing, proportion of mother-supported families in the world, including: 1) data illustrating the trend toward increasing proportions of female-headed and single-parent households (see Chapter 1); 2) analyses of women's economic contributions to households that count both cash income and the market value of all saleable goods and services not remunerated in cash; 3 ) data showing that mothers' work load increases more than fathers' when families grow and that women put more hours into incomegenerating work than men in many places; 4) studies showing that women's cash income is vital to meeting basic family needs and that women often contribute relatively (and sometimes absolutely) more of their income to meeting these needs; and 5) data on determinants of single motherhood.

Statistics on female-headed and single-parent households suggest the prevalence of mother-supported families, but do not provide an exact measure of their numbers for the following reasons:

1. Household headship is determined subjectively by survey respondents, who, when asked to name the head of their household, usually name the oldest male affiliated with the household, even if he is not economically active or in regular residence. ${ }^{1}$ Thus, household-headship data say less about the real economic support structure of households than they say about status hierarchies in households. Households are usually identified as "femaleheaded" only when there is no resident adult male, but almost all "maleheaded households" include adult women and many are, in fact, economically supported by women. For this reason statistics on female-headed households underrepresent the actual number of households that are economically supported by women, many of whom are mothers.

2. Households and families are not synonymous: A large and growing number of families extend beyond the boundaries of households. Data on household headship tell us little, if anything, about the economic organization of these families.

3. Most female-headed and single-parent households are supported by mothers, but some are not: Some female-headed households do not have children; some that do have children are headed by grandmothers, aunts, or women unrelated to the children; a small (but growing) number of single-parent households are headed by fathers; and some single mothers and women identified as household heads are not the sole, or even primary, supporters of 
their households - for example, women receiving substantial remittances from husbands or brothers.

Because of these caveats we cannot assume a one-to-one correspondence between female-headed and single-parent households on one hand, and mother-supported families on the other. No data are currently collected that allow us to determine the exact proportion of mother-supported families in the world; nevertheless we can assert that this proportion is large and probably growing.

\section{Wage-earning and domestic work: mothers' dual productive duties}

In determining who supports families it is imperative to measure the value of noncash work (to which women contribute disproportionately), to identify all income sources, and to document how income is allocated within families. Such an analysis reveals that mothers make - indeed, have always made major economic contributions to their families.

Mothers perform many tasks that are vital forms of economic production, though often not recognized as such because they are not remunerated in cash. An increasing number of mothers are also making cash contributions to their families as more women join the formal labor force - out of necessity as well as in response to new economic opportunities. When both wageearning and non-wage-earning forms of economic activity are accounted for, it becomes evident that mothers provide substantial, primary, or sole economic support to a large proportion of families in the world.

Formal measurements of women's economic activity (which includes all work for pay as well as production and processing of agricultural products, whether for the market or home consumption) indicate that rates among women 15 years and older are highest in Eastern Asia and the former USSR, where roughly 60 percent of women in this age group are economically active. Rates in Southeastern Asia, sub-Saharan Africa, and developed regions (Australia, Europe, Japan, New Zealand, and North America) range from 45

“...mothers provide

substantial,

primary, or sole

economic support

to a large

proportion of

families in the world." to 50 percent. Rates are 32 percent in the Caribbean and Latin America; 24 percent in Southern Asia; 21 percent in Western Asia; and 16 percent in Northern Africa. ${ }^{2}$

In documenting mothers' economic contributions to families, we are forced, once again, to rely on data related to households rather than families. We must also infer mothers' and fathers' relative economic contributions to households from data on women's and men's relative contributions, assuming that a large share of these women and men are mothers and fathers.

Community studies in Nepal find that women contribute an average of 27 percent of household monetary income; however, when economic value is 
"Mothers' earning

strategies and

patterns of time

use change in

response to the

shape and

intensity of their

motherhood role."

attached to all the goods and services they produce - e.g., gathering wood for fuel, collecting and toting water, preparing food - women's average economic contribution to the household rises to 50 percent. $^{3}$ Women in farming households in Thailand contribute an average of half of their households' economic resources when these are calculated to include domestic consumption derived from home production. ${ }^{4}$ An extensive study of how women and men use time in the Philippines indicates that women's share of market income is a third of men's on average; when the economic value of women's home production is added to the equation, women's economic contribution to the household exceeds men's by about 10 percent. ${ }^{5}$ Another study estimates that Indian women contribute 36 percent of India's net domestic product - excluding their services as housewives. ${ }^{6}$ Analyses of data from Ghana indicate that, in terms of market hours of work, 33 percent of households with children were maintained primarily by women in 1988 . $^{7}$

Until recently it was assumed (largely without empirical evidence) that a mother's participation in the labor force compromises the wellbeing of her children. In reality, choosing between working for wages and caring for children is possible only for mothers in developed countries (though fewer and fewer of them) and for a handful of women in the formal labor force of less developed countries who have access to paid domestic help. For the vast majority of the world's women, meeting children's needs requires mothers to engage in both domestic and wage-earning work. As a result, motherhood increases women's overall work load enormously.

Mothers' earning strategies and patterns of time use change in response to the shape and intensity of their motherhood role. Data from the Philippines show that each young child increases the average length of a mother's work week by 8.4 hours and each new infant increases it by 6.5 hours. ${ }^{8}$ In general a mother's participation in the labor force does not excuse her from household responsibilities; as a result, many mothers who work outside the home must sacrifice rest and leisure time to meet all their work responsibilities. In the Philippines working outside the home reduces a mother's rest and leisure time by 28 hours per week, a study reports. ${ }^{9}$

Parallel changes in fathers' work and rest/leisure schedules are not observed. Studies in the Philippines comparing mothers' and fathers' total work time when children are added to the family show that a father's time spent in child care, food preparation, marketing, and other domestic chores averages 1-2 hours daily, regardless of whether he is the father of one child or seven. By contrast, maintaining five children increases a mother's work load by 22 hours per week. ${ }^{10}$

FAMILIES IN FOCUS 
"Some evidence

suggests that, when men and

women live together in a household, men add to, rather than share, women's work load."
Some evidence suggests that, when men and women live together in a household, men add to, rather than share, women's work load. Men's superior bargaining power in the home may allow them to transfer domestic responsibilities to female family members, reducing men's expected work load. In an intensive observational study of child feeding practices in Nicaragua, mothers of 12-18-month-olds were observed to spend more minutes in household production (e.g., cleaning and food preparation) when the father was living with the family than when he was absent. ${ }^{11}$ Data from Ghana show that women who do the least work (domestic and market) live without men; men who do the least work live with women. Women who live with men work an average of 13 hours more per week than men who live with women (see Table 1).

Comparative studies of women's time use in diverse countries show that women (whether mothers or not) work much longer hours than men in general. This disparity is apparent in both developed and less developed countries. One early study of time-use data from 12 countries - including the United States, the former Soviet Union, and countries in Eastern and Western Europe - reports that employed women work roughly 20 percent longer than employed men, on average. ${ }^{12}$ A survey of 17 time-use studies in less developed countries finds that women's work hours exceed men's by 30 percent; ${ }^{13}$ a similar survey estimates the differential to be 40 percent. ${ }^{14}$ Kenya's 1991 census reported that women of reproductive age work 50.9 hours per week, while men of a similar age work 33.2 hours per week, on average. ${ }^{15}$ In rural Java women work an average of 11 hours per day, while men average 8.5 hours per day. ${ }^{16}$

\section{Mothers' cash income: a family necessity}

As subsistence economies modernize, survival and investment in the next generation increasingly require access to cash. Parents' ability to marshal cash for school fees can determine whether or not their children have any hope of entering the modern economy - yet even nominal school fees of US\$25 per year are prohibitive for many families in less developed countries. An African woman described the disintegration of the rural subsistence economy and the changing demands upon families this way: "We farm our land for food and this is good. But we cannot farm for fuel, or soap, or school. For these we need money." ${ }^{17}$

Mothers are the primary or sole source of income in most single-parent households and in many two-parent households as well. Fathers in two-par- 
TABLE I

Differences in men's and women's weekly work hours by living arrangement in Ghana, 1987/88

\begin{tabular}{lccc}
\hline & MARKET WORK & DOMESTIC WORK & TOTAL \\
\hline Male & 27.5 & 4.8 & 32.3 \\
\hline Living with female & 30.7 & 9.2 & 39.9 \\
Not living with female & & & \\
\hline Female & 24.5 & 20.9 & 45.4 \\
\hline Living with male & 20.5 & 19.9 & 40.4 \\
\hline
\end{tabular}

NOTE: Because it is difficult to get a full accounting of time use, we assume that these figures represent an underestimation of weekly work hours. Nevertheless they are illustrative of gender differences in work hours.

SOURCE: Lloyd, Cynthia B. and Anastasia J. Gage-Brandon. 1993. "Women's role in maintaining households: Family welfare and sexual inequality in Ghana," Population Studies 47(1):115-131.

ent homes may earn little or nothing because they cannot find steady, or any, employment or because they are physically disabled or otherwise impaired. In both developed and less developed countries the excessive use of drugs and alcohol by males has been cited among the causes of de facto female-headed households. ${ }^{18}$ A woman from Montserrat describes how this phenomenon affects women in her society:

A lot of West Indian men like to drink. Those that do work to support their families usually do not make enough to support their drinking habits and their families. So women have to go to work too.... Women are used to supporting themselves, so they do it when the men are here and when the men are gone as well. They tell their daughters not to depend on men, but on themselves. They should tell the sons to have responsibilities, but they don't. It is the women who become responsible. ${ }^{19}$

Male un- and underemployment and national debt-reduction programs ("structural adjustment") have increased the pressure on women (and sometimes children) to earn in both developed and less developed countries. The same economic pressures that force mothers to earn income to support their families also break up families - by promoting labor migration or creating 
conflicts over limited income $\mathrm{e}^{20}$ - leaving mothers with even greater economic responsibility for their children (see "Pathways to single motherhood" in this chapter and Chapter 3).

In countries ravaged by the AIDS epidemic, which primarily afflicts people of reproductive age, the disease has increased some women's need to earn by creating single-parent households and requiring women to support extended family members. Caring for the rapidly growing number of AIDS orphans has been largely left to women, whose family support networks may be dramatically depleted by the disease. This situation is illustrated by the case of a woman living with her daughter and teenaged son in Lusaka, Zambia:

Her husband died of AIDS several years ago, followed by an older daughter. Her married son then assumed responsibility for the family, but he too recently succumbed to the disease, leaving a family behind. Now the woman is caring for her younger daughter who also has AIDS, while trying to keep her son in school. ${ }^{21}$

In households with two wage-earning parents, fathers' income usually exceeds mothers' (as is true of men and women in general), yet mothers usually contribute a larger proportion of their income (and sometimes a larger absolute sum) to their household, according to studies in a number of countries (see, for example, Table 2). Recent research on intra-household resource allocation reveals a striking difference between men and women in the proportion of their earnings devoted to meeting basic family needs. ${ }^{22}$ Even in cases in which the father earns substantially more than the mother, the mother's modest income may constitute the primary source of household support if the father contributes only a fraction of his income to meeting family needs.

Fathers' relative cash contribution to their household may be small for a number of reasons. Some fathers contribute a portion of their income to one or more other households in which they are supporting children and/or past or current sexual partners. ${ }^{23}$ In some societies husbands' and wives' relative economic contribution to their families is dictated by cultural norms prescribing that certain expenditures must be made by males and others by females, as a result of which mothers may be expected to provide a disproportionate share of overall and daily family resources. ${ }^{24}$ For example, in much of Africa wives are expected to supply staple foods, while husbands are expected to pay intermittent, visible expenses, such as state-mandated school fees. In other instances husbands are responsible for providing the family house, but the recurring costs of its upkeep, water, and fuel fall to wives. In parts of West Africa monetary exchanges are encouraged between blood kin - e.g., 


\section{TABLE 2}

Wives' and husbands' average monthly income contributions to the household in six villages in South India

\begin{tabular}{|c|c|c|c|c|}
\hline \multirow[b]{2}{*}{ VILLAGE } & \multicolumn{2}{|c|}{$\begin{array}{l}\text { AVERAGE CONTRIBUTION IN } \\
\text { MONTH IN WHICH WIVES' } \\
\text { INCOME IS AT A MINIMUM } \\
\text { (\% of individual's total earnings) }\end{array}$} & \multicolumn{2}{|c|}{$\begin{array}{l}\text { AVERAGE CONTRIBUTION IN } \\
\text { MONTH IN WHICHWIVES' } \\
\text { INCOME IS AT A MAXIMUM } \\
\text { (\% of individual's total earnings) }\end{array}$} \\
\hline & WIFE & HUSBAND & WIFE & HUSBAND \\
\hline 1 & 93 & 71 & 99 & 76 \\
\hline 2 & 80 & 66 & 83 & 73 \\
\hline 3 & 71 & 53 & 89 & 79 \\
\hline 4 & 100 & 85 & 100 & 86 \\
\hline 5 & 99 & 71 & 99 & 85 \\
\hline 6 & 100 & 76 & 100 & 76 \\
\hline
\end{tabular}

between brothers and sisters - rather than between husbands and wives; thus, a man may pay more toward the support of his sister's children than his own.

Fathers sometimes divert a large portion of their income to personal uses; such expenditure patterns unnecessarily intensify mothers' share of economic responsibility for children. ${ }^{25}$ Usually the barest minimum of a woman's income is withheld for what might be called personal expenditures. This is especially true among the poorest of women. A study of 14 typical villages in South India, consisting primarily of poor, landless families, reveals a striking pattern of systematic differences in the proportion of income women and men devote to household uses. While women appear to retain virtually no personal income, men retain up to 26 percent of their earnings for personal use. Though the ratio of husbands' to wives' earnings is typically more than $3: 2$, the proportion of income withheld for personal use by husbands is five to six times the proportion withheld by wives. ${ }^{26}$

Mothers' cash earnings are often critical to children's health and access to health care and education. Evidence from micro-economic household 
studies and macro-level analyses confirm the "child orientation" of mothers' income. ${ }^{27}$ Researchers in Kenya and Malawi recently found that, among sugarcane farmers, "the level of income controlled by women has a positive impact on household caloric intake, over and above the effect of [overall household] income. ${ }^{\text {28 }}$ They also found that "while most femaleheaded households [in Malawi] allocated a larger share of their budgets to food, they spend 25-50 percent less on alcoholic beverages than do maleheaded households." ${ }^{29}$

Projections based on data on 300 children from urban Guatemala suggest that the attainment of an additional half of a standard deviation in children's average height-for-age through improved nutrition would require $\$ 11.40$ per month if earned by the mother but $\$ 166.00$ a month if earned by the father. ${ }^{30}$ Another analysis of these data suggests - as many previous studies have indicated - that the percent of family income earned by the mother positively correlates with children's nutritional status indicators. ${ }^{31}$ Thus, even poor, working mothers can attain respectable health, nutritional, and educational outcomes with a limited income. ${ }^{32}$

Given the fact that a mother's wage-earning work is as vital to family survival as her equally demanding domestic work, it seems logical that families would facilitate the integration of mothers' dual roles. Yet, paradoxically, the very families that rely upon mothers' earnings often encumber them with restrictive notions of appropriate work. Though we commonly attribute women's economic disadvantages to labor market and wage discrimination, severe limits are also often imposed by the family system.

In some societies women must carry on productive work within community or household compounds; in many others propriety dictates that women should pursue only a limited range of jobs and economic activities. Both forms of confinement restrict women's access to remunerative work. Such constraints, upheld by men's authority within the home, can impair mothers' ability to meet either basic family needs or their own.

Mothers' ability to provide for their families is further eroded by a lack of effective control over their own income. In many societies it is common for men to control earnings derived from the economic participation of women in family farming and business, ${ }^{33}$ or even from women's work outside the home. Husbands and elders exacerbate women's poverty when they control women's labor but do not give them fair compensation for their work. In an agricultural development scheme in Cameroon, for example, employers turned over families' wages, including the wives' share, exclusively to husbands. The husbands confiscated 50 percent of their wives' wages for their own use. ${ }^{34}$ Many agricultural modernization schemes result in a double eco- 
nomic assault on women (and, by extension, on their children): Women's labor is diverted to work on crops from which only male family members obtain income, while women are left with inferior land and less time to raise and process the crops needed for family consumption.

\section{Pathways to single motherhood}

Nowhere is mothers' income more vital than in single-parent families. There are a variety of mechanisms by which mothers become single parents: separation, divorce, or abandonment; widowhood; polygamy; nonmarital childbearing; and economic, environmental, public health, and political crises that separate family members.

Separation and divorce. As noted in Chapter 1, divorce rates are increasing in developed countries - and probably in less developed countries as well and a growing proportion of divorces involve couples with young children. In North America and Northern Europe 30 to 55 percent of marriages end in divorce (see Table 10, Chapter 1). In less developed countries an average of about 25 percent of first marriages have dissolved, many as a result of divorce or separation, by the time women are 40-49 years old (see Table 9, Chapter 1). The rupture or attenuation of a parenting partnership generally worsens the economic condition of mother and child (see Chapter 4). Separation or divorce may stigmatize a mother, reducing her social status and shrinking her support network in cases where community members or her ex-partner's kin reject her.

Widowhood. Given that women usually have a higher life expectancy than men and that women are usually younger - sometimes considerably younger - than the men they marry, it is a demographic certainty that a far greater proportion of women than men will be left without a spouse. The number of widows is not insignificant: In India alone in 1991 there were 30 million widows. ${ }^{35}$ In less developed countries in which spousal age differences are traditionally large (7-10 years) and marital fertility continues late in life (e.g., Bangladesh, Ghana, Morocco, Nigeria, and Sudan), widows are often left with dependent children to support.

In some parts of the world, wars have left large numbers of widows with dependent children. This phenomenon has been observed in Afghanistan and regions of the Middle East in the last decade. ${ }^{36}$ Similarly, a study in rural Cambodia shows that fully 20 percent of households are headed by widows. ${ }^{37}$ A recent analysis of data from Vietnam revealed that 21 percent of women 
"...men's multiple

sexual partnerships

are likely to leave

many of the

women who

become mothers

through such

unions

economically

vulnerable. aged 50 to 54 (who were in their twenties and thirties during the Vietnam War) are widows. ${ }^{38}$

Widowhood can have serious financial consequences for women, who may lose property as well as spousal income when their husband dies. In much of sub-Saharan Africa widows often do not inherit from their husbands, regardless of the age and number of their common children or the closeness of the marriage. ${ }^{39}$ After a husband's death, it is not uncommon for his kin to take away key possessions. In some parts of India a widow is seen as being the "cause" of her husband's death and is treated as a "stranger" by her deceased husband's family. Though she may remain in the family compound, she must sleep and eat in a segregated space and provide for herself and her children. In upper-caste communities she is prohibited from working for wages, making the pursuit of a livelihood difficult, if not impossible.

Restrictions on residence, ownership, and employment place widows in a situation of acute dependence on economic support from others, yet such support may not be forthcoming. A study of widows in seven states in India reports that less than half live with adult sons, the most dependable source of economic support for widows. ${ }^{40}$ Surprisingly few widows - less than 10 percent - live with and are supported by in-laws, parents, or brothers. This leaves nearly half of widows, many of whom must also support dependent children, to live and manage on their own.

The economic deprivation and vulnerability of widows is reflected in their high morbidity and mortality rates compared with married women in corresponding age groups. In India mortality rates are 86 percent higher among widows than among married women, a recent study reports. ${ }^{41}$ In Bangladesh there is a measurable increase in the mortality of women after their husbands die if they do not have a number of sons to provide for them and to protect their rights. ${ }^{42}$

The dismal economics of widowhood argue for a full review of the legal and cultural practices contributing to widows' poverty, particularly where they are likely to have dependent children.

Polygamy and multiple unions. Polygamy is a legal institution in some countries and an informal practice in others. Legally sanctioned polygamy is still extensively practiced in a variety of traditional cultures in sub-Saharan Africa and, is allowed under Islam (see Table 3). Polygamous men in positions of influence and relative wealth often contract second and third marriages with women who are much younger than they are.

Social norms and legal systems that encourage, or do not censure, men's multiple sexual partnerships are likely to leave many of the women who 
TABLE 3

Percent of women aged 35-39 in polygamous unions in less developed countries (illustrative data)

\begin{tabular}{lcc}
\hline COUNTRY & YEAR & PERCENT \\
\hline Ghana & 1988 & 43 \\
\hline Kenya & $1988 / 89$ & 26 \\
\hline Morocco & 1987 & 7 \\
\hline Namibia & 1992 & 5 \\
\hline Pakistan & $1990 / 91$ & 64 \\
\hline Senegal & 1986 & 34 \\
\hline Tanzania & $1991 / 92$ & 22 \\
\hline Zambia & 1992 & 54 Surveys. \\
\hline SOURE: Tabulations from Demographic and Health S & \\
\hline
\end{tabular}

become mothers through such unions economically vulnerable. Few men have sufficient wealth to adequately support multiple families and invest equally in each mate and her offspring, ${ }^{43}$ yet in some countries many men continue to father children with multiple partners, often late into their lives. Demographic and Health Surveys report much higher rates of male than female fertility in several African countries, primarily as a result of polygamy. In Ghana women aged 45-49 report having an average of 5.7 surviving children; men aged 50 and over report having an average of 8.5 surviving children. In Mali married women aged 40-49 report having an average of slightly more than four surviving children; men aged 50-55 report having about twice that many surviving children on average. ${ }^{44}$ Much of these men's excess fertility occurs after they are 45 years old; thus many of these fathers are likely to die while the children in their second or third families are still young.

Multiple sexual relationships and families are accepted in many societies. ${ }^{45}$ In Jamaica, for example, it is very common for men to have multiple parenting partners: $34-40$ percent of men participating in one study had two or three parenting partners; 14 percent had four or more. ${ }^{46}$ 
Research conducted to help contain the spread of AIDS has played an important role in demonstrating the frequency of multiple sexual (and sometimes parenting) partnerships.

Nonmarital adolescent childbearing. Within the universe of mother-supported families, those that spring from early and unplanned childbearing are arguably the most socially marginalized. Unprotected early sexual activity often robs a girl of her childhood, impoverishes her in adulthood, and compromises the future of her children. Because unmarried adolescent mothers are likely to have less education, low (if any) income, and an uncertain claim on the father's earnings (if he has any), their prospects - short- and longterm - are often grim.

In the past most adolescent childbearing either took place within, or led to, marriage or a sanctioned union. Indeed, in many less developed countries a girl could be rejected by her spouse, his family, or hers if she failed to conceive soon after sexual relations were established. As the cultural desirability of early marriage has receded, the consequences of adolescent childbearing have become increasingly unfavorable. Current evidence from a variety of settings reveals that women who conceive children at a young age and out of the socially accepted sequence - i.e., marriage, followed by sexual initiation, followed by pregnancy - have poor economic prospects. ${ }^{47}$ As noted in the previous chapter, the proportion of adolescent women giving birth outside of marriage has increased in some countries (e.g., Botswana and Kenya). Though adolescent fertility (inside and outside of marriage) has not increased overall, it does remain high in some regions (see Table 2, Chapter 1).

"The unwilling adolescent mother is plausibly the most vulnerable of all single parents."

Bonds between unmarried, pregnant, adolescent women and the fathers of their children-to-be are typically weak. ${ }^{48}$ Even when an unplanned pregnancy leads to marriage, the union is often unstable. A study in Barbados found that only 23 percent of children of such unions still reside with their fathers by age eight; in Chile, about 40 percent of such children are abandoned and unacknowledged by their fathers by age six. ${ }^{49}$

Sexually active, unmarried adolescents account for a large portion of the unmet need for contraception and safe abortion services in many countries, yet adolescent girls lack effective access to, or power to use, contraception. In Latin America typically no more than one-fifth of sexually active adolescent girls report using contraception at first intercourse and only 20 to 70 percent of unmarried adolescents report using a contraceptive method during their most recent sexual encounter. ${ }^{50}$

Nonconsensual sex plays a significant role in adolescent pregnancy in developed and less developed countries alike. ${ }^{51}$ In a study of a representative 


\section{TABLE 4}

Percent of currently married women living apart from their husband in African countries (illustrative data)

\begin{tabular}{lcc}
\hline COUNTRY & YEAR & PERCENT \\
\hline Botswana & 1988 & 26 \\
\hline Ghana & 1988 & 34 \\
\hline Kenya & 1988 & 22 \\
\hline Nigeria (Ondo State) & $1986 / 87$ & 16 \\
\hline Senegal & 1986 & 20 \\
\hline Zimbabwe & $1988 / 89$ & 29 \\
\hline
\end{tabular}

SOURCE: Tabulations from Demographic and Health Surveys.

sample of adolescent mothers in Seattle, Washington, more than two-thirds reported that they had been sexually abused and 44 percent had been victims of forced intercourse at some point in their lives. ${ }^{52}$ Nearly half of sexually active schoolgirls in Kenya report that their first intercourse was forced or that they were "tricked" into it. ${ }^{53}$ The unwilling adolescent mother is plausibly the most vulnerable of all single parents.

Migration: voluntary and forced. Labor migration may lead to de facto single parenthood for a mother whose migrant husband is absent for extended periods of time. In regions where migration flows are increasing, this condition of single motherhood may be common, at least for a portion of women's lives (see Table 4). While some of the best-supported single mothers are those with migrant husbands or male kin who send back remittances on a steady basis, for many mothers and children left behind the benefits of male migration are illusory.

Men (and women) may initially leave home to earn wages for the family's benefit, but their commitment to sending money home, or the practical possibility of doing so, sometimes fades. Data from Southern Africa suggest that, although remittances to women and children may be substantial during the first year of a migrant male's absence, they appear to dwindle over longer periods of time. ${ }^{54}$ Even repeated day- or week-long absences can weaken mothers' and children's claims to fathers' earnings. ${ }^{55}$ 
"...the number of

years that women

are unmarried,

living apart from

a spouse, divorced,

or widowed...

comprise a sizable

proportion of

women's lives."
One observer writes compellingly that fathers live "away from the cries of their children. ${ }^{56}$ The implication is that a mother left alone with children bears day-to-day witness to the children's needs and is compelled to meet them, unlike the absent father. In some cases migrant men start new families elsewhere, creating a new set of obligations that undercut economic support to the first family. It is understandable, but problematic, that fathers who must reside far from their family for long periods of time might lose their sense of connection to the family.

Forced migration also leaves many mothers with sole responsibility for their children. As noted in the previous chapter, the number of refugees in the world has increased dramatically in the last decade. Refugee streams from all sources are dominated by women and children, who represent 80 percent of the 18 million refugees awaiting resettlement (10 percent more than the average proportion of women and children in the population of a less developed country). ${ }^{57}$ This figure may even be low, given the disturbing fact that younger women are proportionately under-represented in refugee populations, suggesting that substantial numbers are being abducted or detained. ${ }^{58}$ Young widows with children are heavily represented among refugee populations from Cambodia and Vietnam. ${ }^{59}$

Many of those deemed most destitute within refugee populations live in female-headed households. In the Near East it is estimated that roughly 50 percent of the poorest refugee households are headed by women. ${ }^{60}$ Because refugee movements uproot whole communities, family and neighborhood support networks that would usually provide critical assistance to single mothers and widows with young children often disintegrate, leaving refugee mothers to provide the full share of economic and emotional support for their children.

\section{Women's unexpected economic life cycles}

The data on women's actual experiences in family life present a very different picture from the one most women have been raised to expect. In sharp contrast to cultural mythology, the marriage of a girl or woman is not the beginning of a long cycle of economic protection or security. Many women will spend a significant proportion of their reproductive years (15-49) unmarried or living without a partner in residence (see Table 5). After age 49 there is an even higher probability of a woman living apart from a spouse as a result of the increased incidence of widowhood in later life; marital dissolution through divorce, separation, or abandonment may also be common in women's later years. When the number of years in which women are unmar- 


\section{TABLE 5}

Percent of time women aged 20-49 spend unmarried in less developed countries (all available data)

REGION (no. of countries)

West Africa (8)

East Africa (6)

Southern Africa (4)

North Africa/Middle East (5)

Asia (4)

Latin America/Caribbean (10)
PERCENT

13

NOTE: Unmarried is defined as being single, legally separated, divorced, or widowed. Marriage includes informal and consensual unions as well as legal and religious marriages.

SOURCE: Westoff, Charles F., Ann K. Blanc, and Laura Nyblade. 1994. Marriage and Entry into Parenthood. Demographic and Health Surveys Comparative Studies no. 10. Calverton, Maryland: Macro International Inc.

ried, living apart from a spouse, divorced, or widowed are combined, they comprise a sizable proportion of women's lives. This fact underscores the need to preserve and expand women's earning opportunities and legally recognize women's economic rights as individuals rather than as adjuncts to their fathers, brothers, and sons.

The increasing proportion of single-parent households - documented in developed countries and thought by many observers to be occurring in less developed countries as well (see Chapter 1) - coincides with a trend called the "feminization of poverty," in which the poorest quartiles of society are increasingly made up of women and children. A review of data gathered in the mid-1980s from five Latin American cities - Bogotá, Caracas, Lima, Panama City, and San José - indicates that female-headed households are over-represented in the lower-income groups in the last four of these cities; only in Bogotá was there a greater proportion of female-headed households in the total population than in lower-income groups. ${ }^{61}$ The feminization of poverty is also a rural phenomenon. A review of global literature undertaken by the International Fund for Agricultural Development found that in the two decades preceding 1988 the number of rural women living below the 
poverty line increased by 47 percent, while the number of impoverished rural men increased by only 30 percent. ${ }^{62}$

\section{Marriage and motherhood as free choices}

By all indications women want and need satisfying sexual relationships. Most women probably also want to have a close partnership with a man and want to have children (whether because of innate desire or socialization). The issue for most women is not the value of these experiences, but rather the conditions under which they experience them. Women's weak bargaining power in the arenas of sexual relationships, childbearing, and childrearing is the difficulty.

Sexual relationships often bring risks of disease, unwanted pregnancy, and unforeseen lifelong responsibilities. Women's lack of control over their own sexuality and fertility remains one of the most threatening aspects of their lives. Men and women, including husbands and wives, often hold very different views about the need for protection against sexually transmitted diseases and unwanted pregnancy. Even in stable marital unions, discord over the number of desired children and lack of communication concerning sexual matters are common. ${ }^{63}$ Women cite a fear of their partner's disapproval or violence and fear of abandonment as reasons why they cannot use contraceptives. For these reasons some women must select contraceptive methods that they can use in secret, have no detectable side effects, and do not interfere with sexual acts. Women are often unable to gain their partner's compliance for condom use as protection against sexually transmitted diseases, even when their partner is a likely carrier of HIV. ${ }^{64}$ Many women carry responsibility for the most intimate aspects of their partnership alone and unprotected.

What explains the ease with which husbands and families control and direct women - particularly when they become mothers - to act in others' interest before their own? Gender role ideologies are partly to blame: Women are socialized from the time they are little girls to find social affirmation in car-

"Women's lack of control over their own sexuality and fertility remains one of the most threatening aspects of women's lives." ing for and submitting to others. ${ }^{65}$ From their earliest years young girls wait on adults and often on male siblings as well. There may be harsh social penalties for girls and women who defy gender expectations, particularly with respect to family roles. Gender ideologies that curtail women's rights within families, combined with marketplace discrimination against women, impede women's exit from disagreeable, unjust, or even violent family circumstances. ${ }^{66}$ In sum, women's behavior in families is powerfully shaped by economic and social incentives to uphold traditional male-female divisions of labor and social hierarchy. 
"... once married

into families,

many women

appear to be not

much more

secure than they

would be outside

of marriage."
Not only do women have fewer social alternatives than men - having to join or create families almost per force in order to survive - but once married into families, many women appear to be not much more secure than they would be outside of marriage. While the gathering of statistics on violence against women proceeds unevenly, one global study finds that, where such data are recorded, 40 to 80 percent of all physical abuse suffered by women takes place at the hands of a close family member (usually a husband). ${ }^{67}$ The authors conclude that, in terms of both morbidity and mortality, "the home is often the most dangerous place for women and frequently the site of cruelty and torture." An insightful study into the causes of violence against women in Peru notes the significant features of the family system that reinforce women's dependence. These include the "domestic isolation of women where male figures are the final authority, early marriages before women have developed a sense of autonomy, poor communication in family conflicts, the identification of the family as the sole institution that shapes women's identity, and the tendency to treat domestic conflict between men and women as a private matter." 68

What is the fate of a woman who seeks to leave a marriage? What is the value placed on an infertile woman? What future awaits a mother with too few sons? What befalls a woman who chooses to be sexually inactive and/or not to become a mother? In most societies social rejection and economic insecurity attend such choices. Despite the advances of the international women's movement, and much supportive rhetoric from national governments, most women are far from having a true choice regarding their sexuality, marital status, or motherhood.

\section{Conclusion}

Family policies that effectively support women as mothers and as individuals must confront a paradox. The same families that rely upon women to assume ever-growing responsibility for family support and to function as good wives and mothers undermine women in their efforts to fulfill these roles. Abuses of family-based power - in particular, destructive abuses of husbands' superior strength and access to resources - demote women from partners in marriages to juniors in marriage, from effective advocates for their dependents to dependents themselves. These undermining family forces are frequently reinforced in the wider social arena. Women are treated under some systems of family law more as property than as free adults. Women's economic claims are regularly ignored by policy, leaving them doubly discriminated against on the basis of their gender and their normatively ascribed family roles. 
"...being a mother

will be the most

important factor

disposing women

to poverty unless

women's family

roles are more fully

valued and

responsibility for

children is more

equitably balanced

between men and

women."
Not only are women - especially mothers - often not economically protected by spouses and sociery, they often become more economically vulnerable after marriage. This vulnerability increases when wives become mothers. While women may cease being wives, they rarely resign from being mothers and, thus, rarely escape the long-term economic and emotional responsibilities of motherhood.

Nothing in the data we have reviewed suggests that women in the future will be under any less pressure to generate cash income to support their families. The volatility of marital and sexual relationships is also not likely to abate. With pervasive, cross-cultural evidence of shifting family arrangements, diminishing co-residence of spouses, and women's intensifying economic responsibility for children, there can be no plausible justification for policies that limit women's access to economic resources on the basis of their marital or fertility status. Needing a husband's, or father's, or son's consent for women to have access to credit, market activity, or ownership of assets is not only offensive, it is unproductive. The removal of gender bias from economic policy must include removal of explicit or implicit constraints on women based on their sexual, reproductive, or family roles. Tests of women's unencumbered access might include: Can a celibate, childless woman support herself? Can a pregnant, unmarried woman hold a job? Can a poor, working mother procure affordable child care?

Removing gender biases from economic policy may increase women's access to labor markets and reduce the male-female wage gap, but it is not enough to reduce women's disproportionate share of poverty. In the future being a mother will be the most important factor disposing women to poverty unless women's family roles are more fully valued and responsibility for children is more equitably balanced between men and women. Safe and secure motherhood requires a fundamental recognition that women have rights to pursue livelihoods on their own behalf; to enjoy freedom of choice in marriage and childbearing; to find equality in the workplace; and, above all, to share the economic and social responsibilities for children with willing partners. The next chapter explores the extent to which fathers can and do share these responsibilities. 


\section{NOTES}

1. Rosenhouse, Sandra. 1989. "Identifying the poor: Is headship a useful concept?" The Living Standards Measurement Study Working Paper no. 58. Washington, D.C.: The World Bank.

2. United Nations. 1991. Table 6.6 in The World's Women: Trends and Statistics 1970-1990. New York: United Nations.

3. Acharya, Meena and Lynn Bennett. 1982. "Women and the subsistence sector: Economic participation in household decisionmaking in Nepal." Working Paper no. 526. Washington, D.C.: The World Bank.

4. Richter, Kerry and Napaporn Havanon. 1993. "Women's economic contribution to households in Thailand: Implications for national development and social welfare." Report submitted to the United Nations Development Programme.

5. King, Elizabeth and Robert E. Evenson. 1983. "Time allocation and home production in Philippine rural households" in M. Buvinić, M. Lycette, and W. McGreevey (eds.), Women and Poverty in the Third World. Baltimore: Johns Hopkins University Press, p. 51.

6. Mukerjee, M. 1985. "Contributions to and use of social product by women" in Devaki Jain and Nirmala Banerjee (eds.), Tyranny of the Household: Investigative Essays on Women's Work. New Delhi: Shakti Books, pp. 259-274.

7. Lloyd, Cynthia B. and Anastasia J. Gage-Brandon. 1993. "Women's role in maintaining households: Family welfare and sexual inequality in Ghana," Population Studies 47(1):115-131.

8. Popkin, Barry. 1983. "Rural women, work and child welfare in the Philippines" in Buvinić, Lycette, and McGreevey (eds.), cited in note 5, p. 166.

9. Ibid.

10. King and Evenson, cited in note 5.

11. Engle, Patrice L., J. La Montagne, and M. Zeitlin. 1992. "Caring behaviors and nutritional status of weaning age children in Managua, Nicaragua." Report to UNICEF, New York.

12. Szalai, A. 1975. "The situation of women in the light of contemporary time-budget research." Paper prepared for the World Conference of the International Women's Year, Mexico City.

13. Leslie, J., M. Lycette, and M. Buvinić. 1988. "Weathering economic crises: The critical role of women in health" in D. E. Bell and M. R. Reich (eds.), Health, Nutrition, and Economic Crises: Approaches to Policy in the Third World. United Kingdom: Suburn House Publishing Company, pp. 307-348.

14. McGuire, J. and B. M. Popkin. 1990. "Helping women improve nutrition in the developing world: Beating the zero sum game." World Bank Technical Paper no. 114. Washington, D.C.: The World Bank..

15. Hill, C. 1992. "Gender planning and Kenya's development planning processes: A critical evaluation." Master's thesis, York University, Ontario, Canada.

16. Nag, M., N. White, and R. Peet. 1978. "An anthropological approach to the study of the economic value of children in Java and Nepal," Current Anthropology 19:293-306.

17. Hammerslough, C. 1991. "Demographic approaches to studying the effects of maternal mortality on children" in The Effects of Maternal Mortality on Children in Africa: An Exploratory Report on Kenya, Namibia, Tanzania, Zambia, and Zimbabwe. Monograph. New York: Defense for Children International USA.

18. Blumberg, Rae Lesser. 1994. "Women's work, income and family survival strategy: The impact of Guatemala's ALCOSA Agribusiness Project" in Esther Ngan-ling Chow and 
Catherine White Berheide (eds.), Women, the Family and Policy: A Global Perspective. Albany: SUNY Press; Richter and Havanon, cited in note 4.

19. Moses, Yolanda T. 1977. "Female status, the family, and male dominance in a West Indian community" in Ximena Bunster B. et al. (eds.), Women and National Development: The Complexities of Change. Chicago: University of Chicago Press.

20. Bianchi, Suzanne M. Undated. "Marital separation and the economic well-being of children and their absent fathers." Washington, D.C.: U.S. Bureau of the Census, HHES Division.

21. Leonard, Ann (ed.). 1994. Community-Based AIDS Prevention and Care in Africa: Building on Local Initiatives. Case studies from five African countries. New York: The Population Council.

22. Haddad, Lawrence, John Hoddinot, and Harold Alderman (eds.). Forthcoming. Intrahousehold Resource Allocation in Developing Countries: Methods, Models, and Policy. Baltimore: International Food Policy Research Institute and Johns Hopkins University Press.

23. Bledsoe, Caroline. 1993. "The politics of polygyny in Mende education and child fosterage transactions" in Barbara Diane Miller (ed.), Sex and Gender Hierarchies. Cambridge, England: Cambridge University Press.

24. Fapohunda, Eleanor R. 1988. "The nonpooling household: A challenge to theory" in Daisy Dwyer and Judith Bruce (eds.), A Home Divided: Women and Income in the Third World. Stanford: Stanford University Press.

25. Engle, Patrice L. and M. Zeitlin. Forthcoming. "Father's money, mother's money and parental commitment: Nicaragua and Guatemala" in R. Blumberg (ed.), Engendering Wealth and Well-being. Boulder: Westview Press.

26. Mencher, Joan P. 1988. "Women's work and poverty: Women's contribution to household maintenance in South India" in Dwyer and Bruce (eds.), cited in note 24.

27. Thomas, Duncan. 1990. "Intrahousehold resource allocation: An inferential approach," The Journal of Human Resources 25(4):635-664.

28. Kennedy, Eileen and Pauline Peters. 1992. "Household food security and child nutrition: The interaction of income and gender of household," World Development 20(8):1077-1085.

29. Peters, P. and G. Herrera, with T. Randolph. 1989. "Cash cropping, food security and nutrition: The effects of agricultural commercialization among smallholders in Malawi." Final Report to AID, NIPD. Cambridge: United States Agency for International Development, p. 1080.

30. Engle, Patrice L. 1993. "Influences of mother's and father's income on children's nutritional status in Guatemala," Social Science and Medicine 37(11):1303-1312.

31. Engle, Patrice L. 1991. "Maternal work and child care strategies in peri-urban Guatemala: Nutritional effects," Child Development 62:954-965.

32. Bruce, Judith and Cynthia B. Lloyd. Forthcoming. "Finding the ties that bind: Beyond headship and household" in Haddad, Hoddinot, and Alderman (eds.), cited in note 22.

33. Greenhalgh, Susan. 1991. "Women in the informal enterprise: Empowerment or exploitation?" Research Division Working Paper no. 33. New York: The Population Council.

34. Jones, C. 1984. "Intrahousehold contractual arrangements and farming systems research." Paper prepared for the joint Rockefeller Foundation/Ford Foundation conference on Intra-household Processes and Farming Systems Research, Bellagio, Italy.

35. Chen, M. and J. Drèze. 1992. "Widows and well-being in rural north India." Paper prepared for the Development Economics Research Programme no. 40. London: London School of Economics. 
36. Forbes-Martin, S. 1991. Refugee Women. Atlantic Highlands, New Jersey: Zed Books.

37. Ibid.

38. Desai, Sonalde. 1994. Personal communication.

39. Potash, Betty (ed.). 1986. Widows in African Societies: Choices and Constraints. Stanford: Stanford University Press.

40. Chen, Martha. The Lives of Widows in India. Unpublished manuscript.

41. Bhat, P.N. Mari. 1994. "Widows and widowhood mortality in India." Paper presented at the Conference on Widows in India, Bangalore, March.

42. Cain, Mead T. 1978. "The household life cycle and economic mobility in rural Bangladesh," Population and Development Review 4(3):421-438.

43. Bledsoe, cited in note 23 .

44. Lloyd, Cynthia B. 1994. "Family and gender issues for population policy" in Proceedings of the U.N. Expert Group Meeting on Population and Women. New York: United Nations. Shorter version in Laurie Ann Mazur (ed.). 1994. Beyond the Numbers: A Reader on Population, Consumption, and the Environment. Washington, D.C.: Island Press.

45. Elias, Christopher J. and Lori Heise. 1993. "The development of microbicides: A new method of HIV prevention for women." Programs Division Working Paper no. 6. New York: The Population Council.

46. Brown, Janet, Patricia Anderson, and Barry Chevannes. 1993. Report on the Contribution of Caribbean Men to the Family: A Jamaican Pilot Study. Kingston, Jamaica: Caribbean Child Development Centre, School of Continuing Studies, University of the West Indies.

47. Engle, Patrice L. 1992. "Consequences of women's family status for mothers and daughters in Guatemala." Final Report. New York: The Population Council.

48. Morris, Leo. 1993. "Determining male fertility through surveys: Young adult reproductive health surveys in Latin America." Paper presented at side-meeting of the International Union for the Scientific Study of Population Committee on Anthropology and Demography, IUSSP General Conference, August 24-September 1, Montreal, Canada.

49. Russell-Brown, P., P. L. Engle, and J. Townsend. 1992. "The effects of early childbearing on women's status in Barbados." Paper prepared for the joint Population Council/International Center for Research on Women project on "Family Structure, Female Headship and Maintenance of Families and Poverty"; Buvinić, M., J. P. Valenzuela, T. Molina, and E. González. 1992. "The fortunes of adolescent mothers and their children: The transmission of poverty in Santiago, Chile," Population and Development Review 18(2):211-242.

50. United Nations. 1989. Adolescent Reproductive Behavior: Evidence from Developing Countries, vol. 2. New York: United Nations; Singh, S. and D. Wolf. 1990. Today's Adolescents, Tomorrow's Parents: A Portrait of the Americas. New York: Alan Guttmacher Institute.

51. Youri, Pat (ed.). 1994. Female Adolescent Health and Sexuality in Kenyan Secondary Schools: A Survey Report. Nairobi: African Medical and Research Foundation and The Population Council; Rosas, M. Isabel. 1992. "Violencia sexual y política criminal." CLADEM Informativo no. 6. Lima, Peru: Comité Latino Americano para la Defensa de los Derechos de la Mujer.

52. Boyer, Debra and David Fine. 1992. "Sexual abuse as a factor in adolescent pregnancy and child maltreatment," Family Planning Perspectives 24(1):4-12.

53. Youri, cited in note 51 . 
54. Palmer, I. 1985. The Impact of Male Out-Migration on Women in Farming. West Hartford, Connecticut: Kumarian Press, pp. 24 and 29.

55. Hoodfar, Homa. 1988. "Household budgeting and financial management in a lowerincome Cairo neighborhood" in Dwyer and Bruce (eds.), cited in note 24.

56. Whitehead, A. 1981. "'I'm hungry, mum': The politics of domestic budgeting" in K. Young, C. Wolkowitz, and R. McCullagh (eds.), Of Marriage and the Market: Women's Subordination in International Perspective. London: Routledge, Chapman, and Hall.

57. United Nations High Commissioner for Refugees. 1993. The State of the World's Refugees: The Challenge of Protection. New York: Penguin Books.

58. Ibid.

59. Forbes-Martin, cited in note 36.

60 Ibid.

61. United Nations. 1984. La Mujer en el Sector Popular Urbano: América Latina y el Caribe. Santiago, Chile: United Nations, p. 246.

62. International Fund for Agricultural Development. 1992. The State of World Rural Poverty: An Inquiry into Its Causes and Consequences. New York: New York University Press, p. 273.

63. Lloyd, cited in note 44; Bongaarts, John and Judith Bruce. 1994. "The causes of unmet need for contraception and the social content of services." Research Division Working Paper no. 69. New York: The Population Council.

64. Elias and Heise, cited in note 45.

65. Papanek, H. 1979."Family status production: The 'work' and 'non-work' of women," Signs 4.

66. Sen, Amartya. 1990. "Gender and cooperative conflicts" in Irene Tinker (ed.), Persistent Inequalities: Women and World Development. New York: Oxford University Press.

67. Bunch, Charlotte. 1991. "Women's rights as human rights: Toward a re-vision of human rights" in Gender Violence: A Development and Human Rights Issue. New Brunswick, New Jersey: Center for Women's Global Leadership, Douglass College, p. 7.

68. Vasquez, R and G. Tamayo. 1989. Violencia y Legalidad. Lima, Peru: Concytec. Cited in R. Carrillo. 1991. "Violence against women: An obstacle to development" in Gender Violence, cited in note 67, p. 34. 


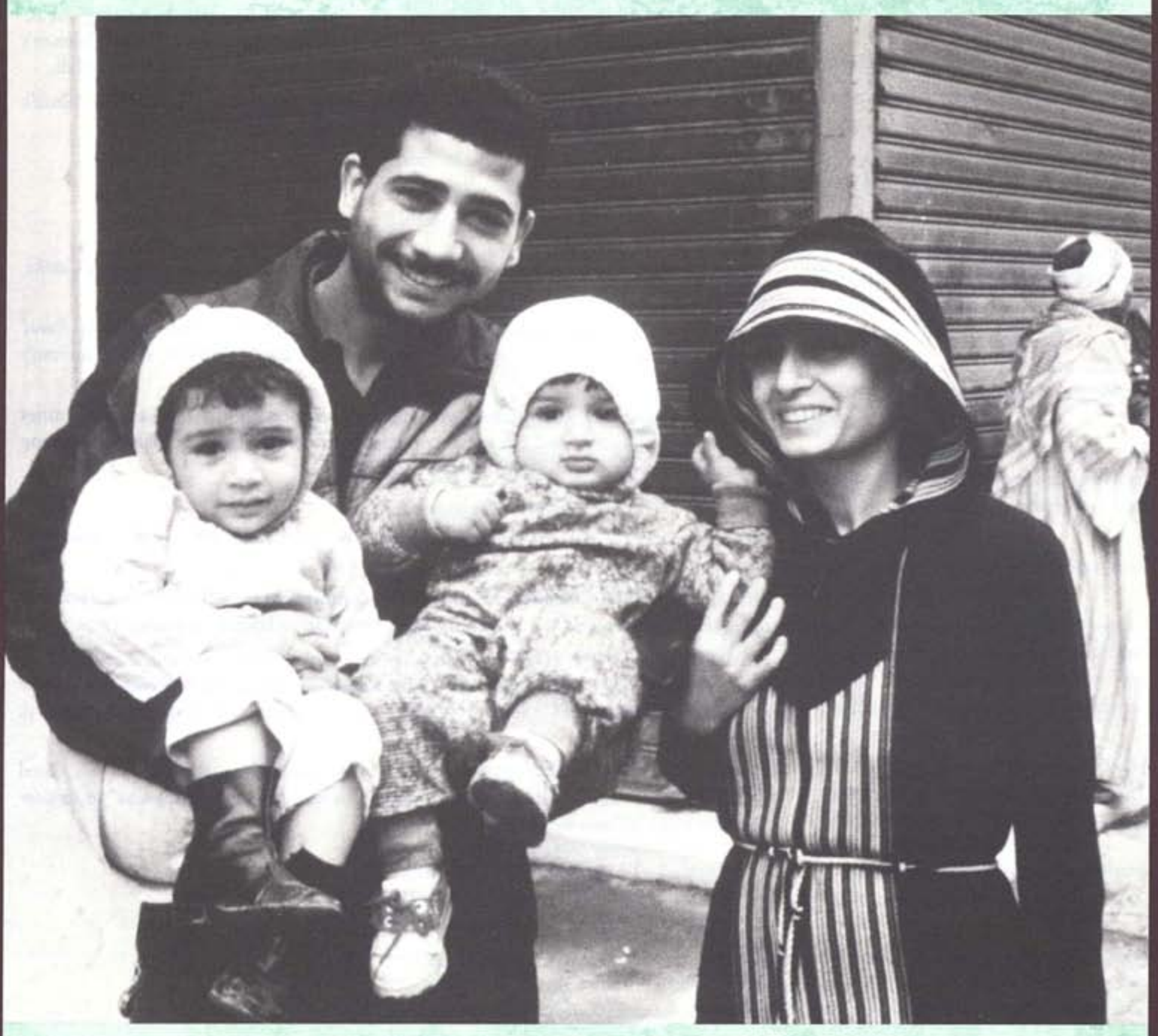




\section{CHAPTER THREE}

\section{Fathers as \\ Parenting Partiners}

Patrice L. Engle and Ann Leonard

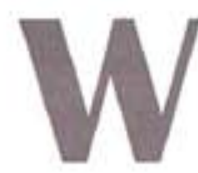

hile women's lives have been characterized primarily in terms of motherhood, men's lives have been characterized largely without reference to fatherhood. Only recently did fatherhood begin to attract concerted research and media attention in the United States and Europe; now interest in fathers is growing among those concerned about the fate of families, the welfare of children, and the quality of men's lives.

This chapter reviews recent research on fathers and discusses factors affecting father-child relationships, the benefits of this bond, and innovative measures to strengthen it. Because of past emphasis on the mother-child link, relatively few empirical studies of fathers have been conducted. Existing data, most of which come from the United States, focus on fathers' economic responsibilities and roles in early child care; less information exists on the fathers of school-aged and adolescent children. Though, as a rule, we avoid using culture-specific data to generalize about all fathers, some of the data from the United States may have relevance to less developed countries in which industrialization, urbanization, and mass media are affecting families much as they do in developed countries.

This chapter draws on two unpublished papers: Engle, Patrice L. and Cynthia Breaux. 1994. "Is there a father instinct? Fathers' responsibility for children." Prepared for the Family Structure, Female Headship, and Intergenerational Poverty program of the Population Council and the International Center for Research on Women; and Leonard, Ann. 1994. "Male parenting: Changing and expanding opportunities for fathers." Prepared for the Population Council. 
A father can be defined in narrowly biological terms as the man who contributes half of a child's genetic material - indeed, many men throughout history have restricted their fathering role to this reproductive function. But fatherhood, like motherhood, is usually understood to embrace a broader range of parenting functions. These may include direct activities - e.g., feeding, cleaning, playing, holding, showing affection, teaching, socializing, disciplining, and modeling appropriate behavior - and indirect activities that benefit children - e.g., providing economic resources, shelter, and protection and offering emotional support to the mother. ${ }^{1}$

The functions that fathers are expected to fulfill, and the extent to which they do fulfill them, vary across and within societies and from one historical period to another. Underlying this diversity are some apparently universal features of fatherhood:

1. The father role is recognized in all societies. The person filling this role is always a man, though he may not be the biological parent of the children for whom he serves as father. ${ }^{2}$ Women may, and often do, carry out family functions traditionally assigned to fathers, but such women are not identified as "fathers."

2. The father role, however ascribed, is perceived as a powerful one. Fathers in most societies are invested with the power (in theory if not practice) to provide their families with economic support; serve as role models for their children (particularly sons); protect their families from harm; and wield authority over children, wives, and other family members.

3. Fathers are capable of nurturing and caring for children. Researchers have observed fathers in warm, nurturing interactions with their infants and young children in a wide range of societies. ${ }^{3}$

4. Fathers in every society contribute less time to direct child care than mothers (on average), though the magnitude of this investment varies across and within societies.

\section{Fathers' contributions to direct child care: the empirical record}

Fathers' time contributions to direct child care have been measured in timeuse studies in a wide range of societies. Some of these studies measure time devoted to specific activities; others measure time contributed to direct child care (or some variant of this term) in general. Studies of the latter sort are not entirely comparable because activities classified as "direct child care" may differ from one study to the next. Such studies also camouflage the fact that fathers do not engage in all child-care activities in equal measure: Fathers are 
"Fathers contribute

about one-third as

much time as

mothers to direct

child care..." more likely to watch children than wash them, for example. Another distinction lost in time-use studies concerns the two connotations of "child care": One refers to the tasks performed in tending to children's physical wellbeing, the other refers to the affective content of these activities. Time-use studies measure the former, not the latter; thus, they do not reveal much about the "caring" content of child care. Despite these limitations, time-use studies do give a rough impression of the extent of father-child involvement.

The extent of fathers' involvement with children under the age of three is important because it is then that children establish strong attachments to their caregivers and require the most attention. A review of ethnographic studies in 186 societies reports that in only 2 percent of the societies do fathers have "regular, close relationships" with their children during infancy and in only 5 percent do they have such relationships when their children are in early childhood. ${ }^{4}$ Observational studies of father-infant contact reveal that these interactions are rare in a wide range of sociocultural groups. ${ }^{5}$ An exception is fathers among the Aka pygmies (hunter-gatherer-traders living in the tropical forests of the southern Central African Republic and the northern Republic of the Congo), who "provide more direct infant care than fathers in any other known society," a researcher reports. ${ }^{6}$ Swedish fathers are also reported to be highly involved with their children when they are young. ${ }^{7}$ In most societies fathers interact more with older children, and then preferentially with sons a gender preference sometimes shared by mothers. ${ }^{8}$ This gender bias is not universal in early child care, however, according to studies in India, Kenya, Nepal, and among Puerto Ricans in the United States.'

In all societies in which parent-child interactions have been observed, fathers do not provide more than a few hours of direct child care per day ${ }^{10}$ and never provide more direct care than mothers (on average). " Fathers contribute about one-third as much time as mothers to direct child care (even less by mothers' estimates), studies in diverse societies report. ${ }^{12}$ Studies comparing women's and men's (versus mothers' and fathers') time contributions to direct child care in a range of countries report similar findings (see Table 1). Though these data refer to men and women in general, a large percent of those observed caring for children are likely to be the children's parents.

Studies that specify time devoted to specific activities show that mothers not only commit more time to child care overall, they also contribute proportionately more time to certain child-care activities. For example, studies in rural Kenya and Nepal report that, in caring for children under the age of three, both mothers and fathers spend most of their time holding children, but mothers also carry out many other intimate tasks that fathers do not, such as feeding and washing children. ${ }^{13}$ 
TABLE I

Mean hours spent in direct child care per week (illustrative data)

\begin{tabular}{lccc}
\hline COUNTRY & YEAR & WOMEN & MEN \\
\hline DEVELOPED COUNTRIES & & \\
Australia & 1987 & 5.8 & 1.6 \\
Canada & 1986 & 4.3 & 1.4 \\
Netherlands & 1980 & 5.5 & 1.5 \\
United Kingdom & 1984 & 3.6 & 1.1 \\
United States & 1986 & 2.0 & 0.8 \\
& LESS DEVELOPED COUNTRIES & & \\
Bulgaria & 1988 & 4.3 & 1.1 \\
Indonesia (Java) & 1973 & 7.2 & 2.6 \\
Nepal & 1979 & 4.8 & 1.1 \\
Poland & 1984 & 4.4 & 2.0 \\
Venezuela & 1983 & 4.0 & 0.7
\end{tabular}

SOURCE: United Nations. 1991. Table 7 in The World's Women 1970-1990: Trends and Staristics. New York: United Nations.

As valuable as physical care is, it is not the only manifestation of fathers' and mothers' commitment to their children. This commitment is also reflected in food preparation and household maintenance; decisionmaking that affects children's access to resources and opportunities; and the generation of income and its application to meeting basic family needs (for more on the last subject, see Chapter 2).

In some societies fathers play the major role in making decisions about children's health and care, particularly when seeking care involves expenditures. $^{14}$ In rural Bangladesh and India, for example, fathers may be totally responsible for selecting food items and making decisions about children's health care. ${ }^{15}$ Mothers' decisionmaking role may be limited by the demands of seclusion: "In rural Bangladesh ... a young mother frequently cannot walk 200 yards across an open field with her infant to obtain assistance at a dispensary." ${ }^{16}$ A mother's decisionmaking power may be greater if she is literate or income-earning. ${ }^{17}$ In Guatemala women report that men are responsible for making decisions about health care in 55 percent of families in which 
women do not earn an income, but in only 11 percent of families in which women earn more than 50 percent of family income. ${ }^{18}$

\section{Factors affecting father-child relationships}

Economic and social setting. The structure of an economy - hunter-gatherer, horticultural, pastoral, or industrial - frames a father's life, including the window of time he has to spend with his children in the course of a day. Fathers in hunter-gatherer societies often have more contact with young children because their day-to-day lives are carried out in close proximity to family members. ${ }^{19}$ In pastoral or horticultural societies fathers' work may take them further from home, resulting in less contact with infants, but greater involvement with older children, particularly sons who labor with their fathers in fields or pastures. ${ }^{20}$ In industrial societies father-child contact is often greatly reduced when fathers shift into wage-earning labor, which usually takes place outside the home. When both father and mother take on such work the pattern can shift again: For example, if both parents are service industry employees and work different shifts, they may have little or no overlap in their working hours, allowing the father to provide child care while the mother is at work (and vice versa). ${ }^{21}$ This is reflected in data showing that fathers who work night shifts are twice as likely to care for young children as those who work during the day. ${ }^{22}$ In any type of economy, poor economic conditions militate against father-child contact when fathers are compelled to migrate in search of work or spend long hours at a job or jobs.

The more a father and mother cooperate in economic activities, the more equitable the distribution of child-care responsibilities between them, studies suggest. A review of 80 preindustrial societies - in which the division of labor by gender is generally less pronounced than in industrialized societies ${ }^{23}$ - reports that father-child contact increases when mothers and fathers engage in subsistence work together. ${ }^{24}$

Fathers' behavior in modern societies is also shaped by social and economic policy. China's one-child population policy, combined with the heavy participation of mothers in the labor force, has reportedly increased fathers' attachment to, and involvement with, their children. Since the policy has been in effect, fathers in urban areas have been observed to be deeply involved with their offspring, caring for them with pride and affection - behavior not typical of Chinese fathers in the past. ${ }^{25}$

Cultural context. Cultural values, beliefs, and norms generate expectations concerning masculinity and fatherhood. How fathers actually behave within 


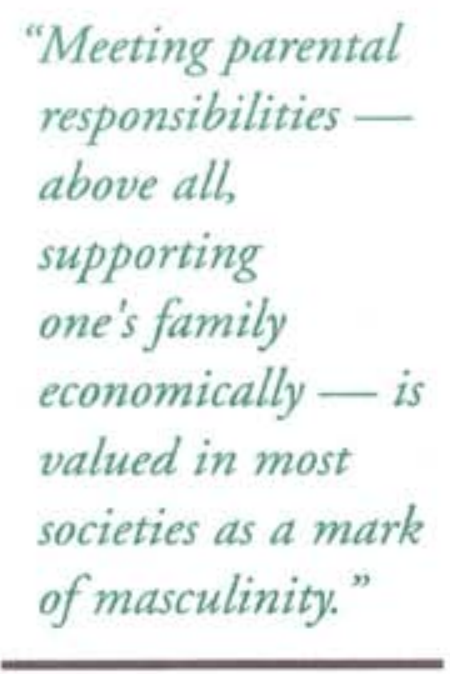

"Meeting parental

responsibilities -

above all,

supporting

one's family

economically - is

valued in most

societies as a mark

of masculinity." these ideological parameters is shaped in every time and place partly by the behavioral precedents set by fathers in the past; partly by current social and economic conditions; and partly by the dynamics of individual families, mother-father relationships, and men's personalities.

Fathering children - in the strictly biological sense - is considered a sign of virility in many societies, particularly in Africa, the Caribbean, and Latin America. In Jamaica it is common for a man to remark to his male friends, as a way of indicating that he is attracted to a woman, "I think I'll give her a baby. ${ }^{126}$ While such macho posturing does not necessarily translate into a lack of affection for or neglect of children, insufficient paternal involvement is recognized to be problematic in Jamaican society. However, one recent study reports that Jamaican men are "far more involved in positively contributing to family life than popular stereotypes suggest." Fathers in this study view their paternal role as providing for their children, counseling them, communicating with them, and being a good role model. Many of the fathers admitted to helping with domestic chores, although few felt that their selfimage was enhanced through such activities. ${ }^{27}$

Meeting paternal responsibilities - above all, supporting one's family economically - is valued in most societies as a mark of masculinity. In the United States, for example, "being a good provider to his family" has been the leading definition of masculinity for the last 20 years, according to the Yankelovich Monitor Survey, an annual poll of social attitudes. Fathers who cannot financially support their families lose prestige and power and may react by retreating from family obligations. This phenomenon has been observed in Latin America, where the inability of many fathers to earn adequate incomes has led to a decline in the authority of working-class fathers and an increase in family abandonment by fathers in some low-income areas. ${ }^{28}$ In the United States many poor, urban fathers retreat from their families when they cannot provide for them economically, seeing no other family role for themselves. ${ }^{29}$

Not all cultures believe that a biological link between father and child confers a special obligation on the father to care for the child. In parts of West Africa children are seen as belonging not simply to their biological parents but to their entire kin group; thus, a father is not expected to be a primary provider for his child. ${ }^{30}$ In most societies the shared biology of father and child does generate the expectation that the father will care for the child in some capacity at some point in the child's life. Fathers in these societies do not invariably treat all offspring equally, however: For example, children's gender and age, parental marital status, and family living arrangements all affect the degree of father-child involvement (as discussed elsewhere in this chapter and in Chapter 4). 
Fathers' minimal participation in direct child care in many societies is linked to cultural beliefs that this is not gender-appropriate behavior. In one area of China men and women believe that fathers are inherently incapable of handling infants $;{ }^{31}$ in some parts of West Africa contact between fathers and very young children is actually taboo. ${ }^{32}$ In Zimbabwe fathers were surprised to learn in an educational seminar that they should play with their children from birth onward to ensure healthy development; they expected to wait until their children could talk before interacting with them. ${ }^{33}$ A study in a small, industrial town in Italy found that men believe it would be culturally inappropriate for them to be involved in the care of babies and young children; furthermore, they feel incapable of providing such care - a view shared by mothers and other family members. ${ }^{34}$ The few societies that do encourage father-infant contact are typically characterized by higher-than-average levels of father-child interaction (e.g., Sweden and Aka society, as previously noted).

As societies modernize, norms and ideals of manhood and fatherhood also evolve - a change that may or may not alter fathers' actual behavior. A case in point is the new ideal of fatherhood that emerged in the United States in the 1960s, galvanized in part by women's increasing participation in the work force and the women's movement and in part by fathers' desire for greater intimacy with their children and a more satisfying family role than that of "wage slave." ${ }^{35}$ The "new fatherhood" proposed an expanded role for fathers, beginning when their children were in utero. The "new father" would attend prenatal classes and would be present at the birth of his children; he would have close, nurturing relationships with his children and a close, coop-

"As societies

modernize, norms and ideals of manhood and fatherhood also evolve..." erative relationship with their mother; he would be an equal partner in child care; and he would share household responsibilities, freeing his partner to pursue an occupation outside the home. Eager "new father" pioneers chained themselves to delivery room tables and were hauled away by police. ${ }^{36}$ The "new father" ideal has since emerged in other countries, including China, ${ }^{37}$ Ireland, ${ }^{38}$ Great Britain, ${ }^{39}$ and countries in West Africa. ${ }^{40}$

While the "new fatherhood" may foster increased nurturance of children, it may also cause ambivalence and tension. Fathers' greater involvement with their children may create conflict in families, communities, and work places in which such behavior clashes with embedded beliefs about appropriate paternal roles. Such fathers may be penalized by employers (e.g., for requesting paternity leave); prevented from acquiring child-care skills by communities that offer no resources to teach these skills to men; or criticized by family members. One study found that "[t]he more men attempted to take an active role in the care of their children, the more mixed or negative feedback they reported from their own parents." ${ }^{41}$ 
“...beliefs about

what fathers

ought to do have

changed far more

than fathers'

actual behavior."
The "new father" ideal may raise some mothers' expectations that their husbands will help more with child care, then give way to resentment when that help is not forthcoming. ${ }^{42}$ Other mothers may discourage their husbands from taking on more direct child-care responsibilities. In two studies in the United States most mothers did not want their husbands to become more involved with their children, though the majority of fathers wanted to do so. ${ }^{43}$ The degree of a father's involvement with his children and his level of satisfaction as a parent are highly correlated with how competent his wife feels he is in caring for children, according to a review of the literature on fatherhood. The reviewers conclude that "the more men feel supported in the parent role by their wives, the more they tend to stay involved in the care of their young children." ${ }^{14}$ Another team of researchers observes that "a kind of vicious circle has developed in which men are presumed incompetent, accept that verdict, and neither seek nor are given a chance to overcome their presumed incompetence. ${ }^{n 45}$

Some mothers' attitudes toward "new fathers" may reflect tension between a genuine interest in sharing more of the child-care burden with fathers and a wish to retain some of their traditional maternal identity and power. As one sociologist observed:

Mothers, even those who want equality in their marriages, often assume a certain impermeable governance of their children. Children are a traditional source of a woman's identity. Women may give lip service to wanting husbands who take on an equal role in raising children, but many will pull rank when an important decision, like how to discipline or what baby sitter to hire, has to be made. ${ }^{46}$

The extent to which fathers in the United States have actually changed their parenting behavior to meet the "new father" ideal is debatable. It has been argued that the beliefs about what fathers ought to do have changed far more than fathers' actual behavior. ${ }^{47}$

Characteristics of the father. Information is limited on how a father's personal characteristics influence his fathering behavior. Available data show that the extent and quality of a father's involvement with his children may vary according to his age, maturity, employment and income status, level of education, and the quality of his relationship with his own parents, particularly his father or father-substitute.

A man's age and maturity can be a benefit or an encumbrance to fathering. Men who father children at a late age put these children at risk of being left fatherless and economically deprived; they also may be less involved in providing direct child care, as suggested by a study of Irish fathers. ${ }^{48}$ On the other hand, a study of African-American fathers reports that those who are 
more "psychologically mature" (defined as adjustment to and acceptance of the parenting role) are more involved in child care. ${ }^{49}$

Low-income or unemployed fathers are less likely to support their children than fathers with more resources, studies of noncustodial Chilean and AfricanAmerican fathers report. ${ }^{50}$ This is not the case in Argentina, however, where noncustodial fathers who are economically better off - i.e., white collar workers and professionals - are the most delinquent in child-support payments. ${ }^{51}$

Fathers who are more educated are more likely to be involved with their children, according to studies of African-American fathers. ${ }^{52}$ However, a study in Chile reports that fathers who are currently in school are much less likely to support their children (probably because they lack the economic means to do so) than those who are not in school. ${ }^{53}$

Some evidence suggests that good fathering begets good fathering. Urban African-American men who had experienced a positive relationship with a father or father-substitute who cared for and sacrificed for them are more likely to be responsible fathers themselves, a researcher reports. ${ }^{54}$

The father-mother relationship. Fathers' involvement with their children is often influenced by the state of the father-mother relationship - notably the strength and exclusivity of the bond - and by family living arrangements. "Some men see parenting and marriage as part of the same bargain - a package deal; it is as if they stop being fathers as soon as the marriage is over," a team of researchers observes with reference to divorced fathers in the United States. ${ }^{53}$ In a study in Jamaica fathers report that interactions with their children are usually severely curtailed when the children live apart from them, particularly when they live in the home of another man. "[T]here seemed to be an implicit attitude on the part of men to respect each other's rights over women, even at the expense of the father-child bond," the researcher observes. ${ }^{56}$

Studies in the United States show that contact between a child and his or her father begins to diminish soon after a parental union dissolves: In a nationally representative sample of 11-to-16-year-old children living in mother-headed households, almost half had not seen their father in the previous 12 months. ${ }^{57}$ Economic support - a vital part of fathering - also declines, sometimes abruptly, when parents separate. In western Europe delinquency in child-support payments occurs in 25 to 40 percent of cases. ${ }^{58}$ Recent data indicate that 40 percent of divorced fathers in the United States pay no child support. ${ }^{59}$ Two studies in Asia find similar patterns of radically reduced child support from fathers following divorce. In Malaysia only 50 percent of divorced fathers contribute financially to their children's care, even though doing so is required under Islamic law. ${ }^{60}$ In Japan 75 percent of divorced 


\section{"Addressing the broader issue of gender relations is vital to improving mother-father relationships, thereby supporting father-child bonds."}

fathers have never paid any child support. ${ }^{61}$ In Mexico divorce and childmaintenance laws clearly mandate noncustodial fathers' continued support for children, but a labyrinthine court process, combined with limited enforcement, results in far fewer children receiving support than ought to. ${ }^{62}$ In Botswana, Lesotho, Mozambique, Swaziland, Zambia, and Zimbabwe fathers are court-ordered to pay child support only if it has been shown that they have failed to provide any support at all; fathers are not liable in cases of intermittent, unreliable support. ${ }^{63}$ In Jamaica a father is held responsible for providing child support only to the children with whom he lives, who may not necessarily be his biological offspring. ${ }^{64}$ In Chile a study found that 42 percent of fathers of children born to adolescent mothers were providing no child support six years after their child's birth. ${ }^{65}$ In Argentina only 36 percent of divorced fathers pay child support with any regularity. ${ }^{66}$

Fathers generally feel even less obligation to pay child support when they were never married to the child's mother. In an effort to protect children's right to paternal support in such cases, governments and women's organizations in a number of countries have pressed to increase the categories of children for whom fathers are legally responsible. In the United States such efforts have resulted in a 50 percent increase in the number of cases in which paternity has been legally established for children born out of wedlock. ${ }^{67}$

Customs surrounding the establishment of paternity vary. In many countries (e.g., Botswana, Guatemala, and Zambia) the onus is on mothers to furnish proof of their child's paternity. Zimbabwe, by contrast, requires a man to prove that he could not have been the father of a child by supplying evidence that he is sterile or was out of the country at the time of conception or, in rare cases, by submitting to a blood test. ${ }^{68}$ Argentina has added a new dimension to policy in this area: The government is empowered to take legal action to establish paternity, not only to promote child maintenance but also to ensure children's right to know their origins. ${ }^{69}$

Noncustodial fathers offer a variety of excuses for not supporting their children, including the claim that a child is not their own or that someone else has taken their place as a father. Some noncustodial fathers may wish to provide support but are prevented from doing so by mothers who do not allow them to see their children; others may lack adequate financial resources, as noted in the previous section. While conceding that some noncustodial fathers would like to see or support their children but cannot, one researcher argues that the most common reason that such fathers are not involved with their children is that they simply have weak attachments to them. ${ }^{70}$

Antagonism between parental partners, married or not, can strain or break the father-child relationship (though it appears to have less impact on 
the mother-child relationship). ${ }^{71}$ This antagonism may reflect profound distrust between men and women in general in some societies. Addressing the broader issue of gender relations is vital to improving mother-father relationships, thereby supporting father-child bonds. But given what appears to be a global tendency for father-child links to weaken or break when parents separate or divorce, fathers must be encouraged to establish independent bonds with their children that transcend the father-mother relationship and are strong enough to survive the dissolution of a parental union.

\section{Benefits of father-child involvement}

In sorting out fathers' roles, the focus should be on the functional impact of fathers in children's lives. An abusive or economically noncontributing father is not likely to be an asset to a child, while a caring and contributing father is - regardless of whether or not the father and child live together or are biologically related.

There is considerable evidence that children and parents benefit greatly when fathers are actively and affectionately involved with their children. Studies in the United States have shown that infants whose fathers are highly involved with them score higher on preschool intelligence tests than infants whose fathers are less involved. ${ }^{72}$ A study of the eight-year-old children of adolescent mothers in Barbados found that children who performed better in school had more-involved fathers than those who did not perform as well, whether or not the children's fathers resided with them. ${ }^{73}$ The quality of a father's interactions with his young child (specifically, his sensitivity to the toddler's needs) may be a better predictor of the child's cognitive performance than the overall amount of time spent with the child. ${ }^{74}$

Attachment studies reveal that children become attached to their fathers by the end of their first year of life, regardless of how much time father and infant spent together. ${ }^{75}$ Children who are securely attached to at least one parent are reported to be more socially responsive than those not attached to either parent, ${ }^{76}$ suggesting that a child's secure attachment to his or her father can offset a poor attachment to the mother.

Engaged fathering increases children's emotional and social wellbeing. A number of studies in the United States of fathers who provide 40 to 45 percent of child care to their preschool-aged children indicate that these children demonstrate "increased empathy, less sex-stereotyped beliefs, and a more internal locus of control," a researcher reports. ${ }^{77}$ Several other studies also suggest that children, particularly boys, exhibit more empathic behavior toward others when their fathers have been actively engaged in child care. ${ }^{78}$ 
The role of fathers in the lives of children in low-income, urban, AfricanAmerican families has received much attention. In these families, the presence of a biological or socially ascribed father has been shown to have a positive effect on the cognitive development of children, especially boys, and is associated with children having fewer behavioral problems, more sense of their ability to do things, and higher self-esteem. ${ }^{79}$

Not surprisingly, the availability of a father's income is associated with improved child outcomes. ${ }^{80}$ Evidence is emerging that the proportion of a father's income devoted to family needs, not simply the absolute amount of the contribution, is positively correlated with child welfare. A recent study of two-parent households in Guatemala reports a significant positive association between child nutritional status and the percent of fathers' income contributed to the household, but not between child nutritional status and fathers' total income or amount of income contributed to the household. ${ }^{81}$ The researcher speculates that fathers who contribute a higher-than-average percent of income to their family may have a greater commitment to their children. The hypothesis that a father's proportionate devotion of income to the household is a proxy for his commitment to his family would be interesting to investigate further.

Children raised primarily by their fathers do not differ markedly from those raised primarily by their mothers, according to studies in Australia, Israel, Sweden, and the United States. ${ }^{82}$ These studies show that the gender of a child's principal caregiver does not substantially affect the child's sex-role orientation or relationship with the father. Slight effects were seen for other variables: Sons raised by "primary caretaking fathers" showed slightly more cognitive development than sons raised by mothers, and both sons and daughters raised by "primary caretaking fathers" demonstrated less impulsivity. While these findings engender confidence in fathers' ability to care for children, we cannot draw too many conclusions about mothers' and fathers' relative strength as parents because the proportion of families with fathers who serve as primary caretakers is so small.

Fathers also benefit from being more involved with their children, studies indicate. In one study of Australian fathers who served as primary caregivers to their children, few report that they did so because they wanted to be with their children, but many express satisfaction in knowing their children better than they would otherwise. Fathers who had exclusive responsibility for child care at some point report that this intensive experience developed their caregiving skills and confidence. ${ }^{83}$ 
While the literature on fathers remains thin, the discourse continues through empirical efforts to break down the barriers to men's involvement with children. These barriers include limiting belief systems and cultural representations; lack of skills and information; insufficient economic opportunities for men; and an inadequate framework of policies, programs, laws, and social incentives promoting fathers' attachment to and support for their children. Efforts in this area are finally beginning to balance the longstanding interest in the mother-child link with attention to the equally vital father-child bond. These efforts are also helping to create a more sympathetic atmosphere in which boys and men can include engaged fathering in their masculine identity.

Programs to support fathers must begin by grappling with cultural beliefs that inhibit men's involvement with children. A fathers' support program in the Caribbean hypothesizes that men's lack of knowledge about fathering is the biggest impediment to father-child relationships. ${ }^{84}$ First-time mothers are similarly ignorant, but societies foster child-care skills in girls and encourage females of all ages to care for children. Boys and men lack the equivalent societal support and context for learning child-care skills.

Studies in Cameroon and the United States suggest that education of fathers, combined with interactive experience, can strengthen father-child bonds. ${ }^{85}$ Some school-based programs provide boys (and girls) with hands-on experience caring for children, which allows them to gain a more realistic view of parenthood and family life. ${ }^{86}$ For example, a program in New York City's Collegiate Preparatory School allows fifth- and sixth-grade boys to diaper, feed, and play with babies. This program demonstrates that "boys, when they are given permission, can become enthusiastic and tender in relating to babies and young children," an observer reports. ${ }^{87}$ Boys who have enrolled in such programs demonstrate increased skills and confidence. Tentative evidence suggests that, at some sites where such programs are underway, rates of adolescent pregnancy may be declining. Whether this decline is causally linked to the programs remains unclear. ${ }^{88}$

Programs designed for fathers include the Young Unwed Fathers Pilot Project underway in six cities in the United States, which mostly serves lowincome African-American men. Through job training and discussion groups (which use a Fatherhood Development Curriculum) the program aims to increase fathers' employment prospects; educate them about responsible sexual behavior, fathers' legal rights and responsibilities, and interpersonal skills; and promote dialogue about parenthood. ${ }^{89}$ 
A group of researchers, with many years of experience documenting attempts to increase fathers' involvement in child-care programs for low-income families in the United States, cautions against prescribing only one way for fathers to increase their involvement with children. These researchers recommend that fathers be presented with a menu of options for becoming involved with children. ${ }^{90}$

Until very recently virtually all educational materials on parenting were aimed at current or future mothers; now a small number are directed at boys and men. These include a parenting guide for men published by the Caribbean Child Development Centre in Jamaica, titled "Men and Their Families: Pathways to Parenting." In Colombia the government is seeking to engage more men in family planning and to redraw the boundaries of publicly projected images of masculinity: Informational brochures distributed by national child health programs use images of fathers to encourage more male involvement with children. In Mexico the Program for Appropriate Technology in Health found that men and women remembered instructions for oral rehydration therapy better when they were presented in pamphlets that included both male and female figures. ${ }^{91}$ Evidence that mothers' attitudes strongly influence fathering behavior suggests that educational programs and materials should encourage girls and mothers to support male involvement with children. ${ }^{92}$

Fathers' participation in prenatal classes, delivery, and postpartum programs, if not actually discouraged, has been largely an afterthought. The inattention to fathers in these contexts deprives children and fathers of the bonding that benefits both. A study in Ireland found that men who participated in prenatal classes and were present during childbirth were far more likely to be actively involved in direct child care one year after their child's birth. ${ }^{93}$ Despite such evidence, the health establishment, employers, and government policymakers have yet to fully sanction men's involvement in the childbirth process. Hospital environments and practices sometimes directly interfere with father-child bonding (as well as mother-child bonding). In Great Britain, where almost all fathers are present at delivery, the warmth and closeness fathers feel for their newborn children is often "dissipated by the insensitive intrusion of medical staff and female relatives and by the demands of work," an observer reports. ${ }^{94}$ Similar observations were made in the United States. ${ }^{95}$ These findings suggest that not only must the resistance to fathers' presence in prenatal, childbirth, and postpartum environments yield, but the very structure of these environments needs revision.

Some efforts have been made to depict participatory fathers in the mass media. Television, film, and advertising in the United States increasingly depict close father-child relationships. In Sweden advertising campaigns have been used to convince fathers that they should share responsibility for child 
"As society

recognizes its

responsibilities

to children

more fully, the

requirements

for a strong

parent-child

bond will prevail over gender role

stereotypes." care. A popular Swedish cartoon character created for the ad campaign, named Alfons Aberg, lives with and is cared for by his single father. ${ }^{96}$

The provision of paternity leave and flex time for fathers is an important step in promoting fathers' involvement with their children. Recognition of the need for paternity leave policies has spread beyond Europe and North America: In Tanzania the national family planning association, UMATI, has recommended leave time for new fathers, noting that it would "enable fathers to support their wives during and after delivery. ${ }^{\text {"97 }}$ Studies in the United States and Sweden show, however, that, where these policies exist, fewer than 10 percent of men avail themselves of them. ${ }^{98}$ A 1986 study revealed that 90 percent of companies in the United States that allowed men to take time off when a child is born referred to the policy as "personal leave" and made no attempt to inform new fathers that this time could be used as paternity leave. ${ }^{97}$ In Sweden, where paternity leave policies have existed for some time, employers often take a negative attitude toward male employees who take paternity leave, a researcher reports. ${ }^{100}$

Government policies of different types increasingly reflect a recognition of the positive role of fathers in their children's lives. Some measures promote father-child involvement, while others seek to assure or guarantee it, even when marriages dissolve. An example of the former is the extension of family leave to both men and women, which recognizes that fathers handle child illness and crises (as well as the acute needs of older dependents) just as mothers do.

Changes in child custody procedures reflect societal willingness to override conventional beliefs that a parent of one gender or the other has a special claim to children. There is a slight but appreciable trend in some developed countries to award custody of children to fathers. In Zimbabwe civil courts award custody on the basis of the best interests of the child (which includes consideration of the effectiveness and living circumstances of the parents), regardless of traditional dictates that children "belong" to the maternal or paternal lineage. ${ }^{101}$

As society recognizes its responsibilities to children more fully, the requirements for a strong parent-child bond will prevail over gender role stereotypes. Then the debate over an adequate level of child support following divorce will be interpreted less often as a private struggle between mothers and fathers and will be viewed more often as a matter of establishing societal accountability for children's wellbeing.

In June 1994 UNICEF and the Population Council co-sponsored a consultation on the roles of men and fathers, a subject that has received little programmatic attention. The enthusiastic tenor of the meeting encouraged 
UNICEF to make fatherhood the subject of the next annual seminar to be sponsored by its International Child Development Centre. The seminar will be titled "Males in Families: Achieving Gender Equality."

This choice of a topic by an organization whose logo is a mother cradling a child is not merely symbolic. It marks a major paradigm shift in the global thinking about fathers' roles in families. A consensus is emerging that fathers must be viewed as more than financial backers of the core family unit defined as mother and children. Fathers are themselves an integral part of the core family unit. Given the will and wise policy support, fathers can play a vital, expanded role in children's lives.

NOTES

1. Hewlett, Barry S. 1992. "Husband-wife reciprocity and the father-infant relationship among Aka pygmies" in Barry S. Hewlett (ed.), Father-Child Relations: Cultural and Biosocial Contexts. Hawthorne, New York: Aldine de Gruyter, pp. 153-176.

2. Draper, P. and H. Harpending. 1982. "Father absence and reproductive strategy: An evolutionary perspective," Journal of Anthropological Research 38:255-273.

3. Australia: Russell, G. 1986. "Primary caretaking and role-sharing fathers" in Michael E. Lamb (ed.), The Father's Role: Applied Perspectives. New York: John Wiley and Sons, Inc., pp. 29-57. United StaTeS: Cox, M. J., M. T. Owen, and V. K. Henderson. 1992. "Prediction of infant-father and infant-mother attachment," Developmental Psychology 28:474; Pedersen, F. A., B. J. Andersen, and R. L. Cain. 1980. "Parent-infant and husband-wife interactions observed at age 5 months" in F. A. Pedersen (ed.), The Father-Infant Relationship: Observational Studies in the Family Setting. New York: Praeger Publishers, pp. 71-86; Parke, R. D. and B. Neville. 1987. "Teenage fatherhood" in S. L. Hofferth and C. D. Hayes (eds.), Risking the Future: Adolescent Sexuality, Pregnancy, and Childbearing. Washington, D.C.: National Academy Press, pp. 145-173. Mexico: Bronstein, P. 1984. "Differences in mothers' and fathers' behaviors toward children: A cross-cultural comparison," Developmental Psychology 6:995-1003. SWEDEN: Lamb, Michael E. et al. 1982. "Mother-and father-infant interaction involving play and holding in traditional and nontraditional Swedish families," Developmental Psychology 18:215-221. AKA PYGMIES: Hewlett, Barry S. 1987. "Intimate fathers: Patterns of paternal holding among Aka pygmies" in Michael E. Lamb (ed.), The Father's Role: Cross-Cultural Perspectives. Hillsdale, New Jersey and London: Lawrence Erlbaum Associates, Publishers, pp. 295-330; Hewlett, cited in note 1.

4. Barry, H. and L. M. Paxson. 1971. "Infancy and early childhood: Cross-cultural codes 2," Ethnology 10:466-508. 
5. URBAN INNER MONGOLIA: Jankowiak, W. 1992. "Father-child relations in urban China" in Hewlett (ed.), cited in note 1, pp. 345-363. Australian abORIGINES: Hamilton, A. 1981. Nature and Nurture: Aboriginal Child-rearing in North Central Armhem Land. Canberra: Australian Institute of Aboriginal Studies. KALAHARU DESERT !KUNG: West, M. M. and M. J. Konner. 1981. "The role of father in anthropological perspective" in Michael E. Lamb (ed.), The Role of the Father in Child Development. New York: John Wiley and Sons, Inc.; Hewlett, cited in note 3. BLACK CARIBS IN Belize, logoli in Kenya, Newar in Nepal, Samoans in American Samoa: Munroe, R. L. and R. H. Munroe. 1992. "Fathers in children's environments: A four culture study" in Hewlett (ed.), cited in note 1, pp. 213-230.

6. Hewlett, cited in note 1, p. 169.

7. Lamb et al., cited in note 3 .

8. Lamb, Michael E. 1987. "Introduction: The emergent American father" in Lamb (ed.), cited in note 3, pp. 3-25; Bronstein, Phyllis. 1988. "Father-child interaction" in Phyllis Bronstein and Carolyn Pape Cowan (eds.). Fatherhood Today: Men's Changing Role in the Family. New York: John Wiley and Sons, pp. 107-124. JAmaicA: Justus, J. B. 1981. "Women's role in West Indian society" in F. Steady (ed.), The Black Woman CrossCulturally. Cambridge, Massachusetts: Schenkman. Thalland: Tulananda, O., D. M. Young, and J. L. Roopnarine. Forthcoming. "Thai and American fathers' involvement with preschool-aged children," Early Child Development and Care.

9. INDIA: Roopnarine, J. L. et al. 1990. "Characteristics of holding, patterns of play, and social behaviors between parents and infants in New Delhi, India," Developmental Psychology 26(4):667-673. KenYa And Nepal: Paolisso, Michael. 1994. "Gender differences in adult care practices in Nepal and Kenya." Report prepared for the Population Council. PUERTO RICANS IN THE UNITED STATES: Roopnarine, J. L. and M. Ahmeduzzaman. 1993. "Puerto Rican fathers' involvement with their preschool-aged children," Hispanic Journal of Behavioral Sciences 15(1):96-107.

10. JAMAICAN MEN living with a common-law wife and a child less than two years old: Roopnarine, J. L. et al. 1994. "Father involvement in childcare and household work in common-law dual-earner and single-earner Jamaican families." Unpublished report. INTACT AFRICAN-AMERICAN FAMILIES: Hossain, Z. and J. L. Roopnarine. Forthcoming. "Division of household labor and child care in dual-earner African American families with infants," Sex Roles; Ahmeduzzaman, M. and J. L. Roopnarine. 1992. "Sociodemographic factors, functioning style, social support, and fathers' involvement with preschoolers in African-American families," Journal of Marriage and the Family 54:699-707. MAINLAND PUERTO RICAN FAMILIES: Roopnarine and Ahmeduzzaman, cited in note 9. EURO-AMERICAN famiues: Russell, G. and N. Radin. 1983. "Increased paternal participation: The father's perspective" in Michael E. Lamb and A. Sagi (eds.), Fatherhood and Family Policy. Hillsdale, New Jersey: Lawrence Erlbaum Associates, Publishers, pp. 139-166.

11. For example: Mackey, W. C. and R. D. Day. 1979. "Some indicators of fathering behaviors in the United States: A cross-cultural examination of adult male-child interaction," Journal of Marriage and the Family 41:287-298.

12. PUERTO RICO: Roopnarine and Ahmeduzzaman, cited in note 9. EURO-AMERICAN FAMILIES in which the mother is unemployed: Pleck, J. H. 1985. Working Wives/Working Husbands. Beverly Hills: Sage Publications, Inc.. African-American famiLIES: Hossain and Roopnarine, cited in note 10.

13. Paolisso, cited in note 9 .

14. Engle, Patrice L. 1994. "Child care practices and ARI." Report to the World Health Organization Acute Respiratory Infection Program. Unpublished report. 
15. Engle, Patrice L. 1994. "Men in families: Report of a consultation on the role of men and fathers in achieving gender equality." Final draft. Consultation held 13-14 June 1994, UNICEF, New York.

16. Caldwell, J. C. and R. M. Douglas. 1993. "Maternal care and coping behaviour: Applying health transition research findings to ARI intervention programmes." Report to the World Health Organization Acute Respiratory Infection Program. Unpublished report.

17. Kahn, M. E. et al. 1987. "Inequalities between men and women in nutrition and family welfare services: An in-depth enquiry in an Indian village." World Employment Program Working Paper no. 158. Geneva: International Labour Office.

18. Engle, Patrice L. 1993. "Influences of mothers' and fathers' income on child nutritional status in Guatemala," Social Science and Medicine 37(11):1303-1312.

19. Munroe and Munroe, cited in note 5.

20. Tronick, E. Z., G. A. Morelli, and P. K. Ivey. 1992. "The Efe forager infant and toddler's pattern of social relationships: Multiple and simultaneous," Developmental Psychology 28:568-577.

21. Presser, Harriet B. 1989. "Can we make time for children? The economy, work schedules, and child care," Demography 26(4):523-544.

22. O'Connell, Martin. 1993. "Where's Papa! Fathers' roles in child care." Policy Reports no. 20. Washington, D.C.: Population Reference Bureau.

23. Schlegel, A. and H. Barry. 1986. "The cultural consequences of female contribution to subsistence," American Anthropologist 88:142-150.

24. Katz, M. M. and M. J. Konner. 1981. "The role of the father: An anthropological perspective" in Lamb (ed.), cited in note 5, pp. 155-185.

25. Breaux, Cynthia. 1993. Personal interview.

26. Brody, Eugene B. 1981. Sex, Contraception, and Motherhood in Jamaica. Cambridge, Massachusetts: Harvard University Press.

27. Brown, Janet. 1993. "Gender relations and conflicts in fathering" in Janet Brown, Patricia Anderson, and Barry Chevannes (eds.), The Contribution of Caribbean Men to the Family: A Jamaican Pilot Study. Kingston, Jamaica: Caribbean Child Development Centre, University of the West Indies.

28. Kaztman, R. 1992. "Why are men so irresponsible?" Cepal Review 46:45-87. Kaztman notes that "very little is known of the conditions under which men accept or reject the obligations connected with stable fulfillment of their roles as husband and father" (p. $80)$.

29 Parke and Neville, cited in note 3.

30. Nsamenang, B. A. 1992. "Perceptions of parenting among the Nso of Cameroon" in Hewlett (ed.), cited in note 1, pp. 321-344.

31. Jankowiak, cited in note 5 .

32. Nsamenang, cited in note 30 .

33. Bernard van Leer Foundation. 1992. "Where have all the fathers gone?" Newsletter 65:1-22.

34. New, Rebecca S. and Laura Benigni. 1987. "Italian fathers and infants: Cultural constraints on paternal behavior" in Lamb (ed.), cited in note 3, pp. 139-167.

35. Furstenberg, F. 1988. "Good dads-bad dads: Two faces of fatherhood" in A. J. Cherlin (ed.), The Changing American Family and Public Policy. Lanham, Maryland: Urban Institute Press. 
36. Arms, S. 1975. Immaculate Deception: A New Look at Women and Childbirth in America. San Francisco: Houghton Mifflin.

37. Ho, D. Y. F. 1987. "Fatherhood in Chinese culture" in Lamb (ed.), cited in note 3; Jankowiak, cited in note 5 .

38. Nugent, J. K. 1991. "Cultural and psychological influences on the father's role in infant development," Journal of Marriage and the Family 53:475-485.

39. Jackson, S. 1987. "Great Britain" in Lamb (ed.), cited in note 3.

40. Nsamenang, cited in note 30 .

41. Cowan, Carolyn Pape and Philip A. Cowan. 1987. "Men's involvement in parenthood: Identifying the antecedents and understanding the barriers" in Phyllis W. Berman and Frank A. Pedersen (eds.), Men's Transitions to Parenthood: Longitudinal Studies of Early Family Experience. Hillsdale, New Jersey: Lawrence Erlbaum Associates, Publishers.

42. Levine, J. A., D. T. Murphy, and S. Wilson. 1993. Getting Men Involved: Strategies for Early Childhood Programs. New York: Scholastic, Inc.

43. Pleck, J. H. 1982. "Husbands' and wives' paid work, family work, and adjustment." Working Paper. Wellesley, Massachusetts: Wellesley College Center for Research on Women; Quinn, R. P. and G. L. Staines. 1979. The 1977 Quality of Employment Survey. Ann Arbor, Michigan: Survey Research Center. Cited in Lamb (ed.), 1987 , cited in note 3.

44. Cowan and Cowan, cited in note 41 .

45. New and Benigni, cited in note 34 .

46. Schwartz, Pepper. 18 August 1994. "When dads participate, families benefit," The New York Times, p. C8.

47. LaRossa, R. 1988. "Fatherhood and social change," Family Relations 37:451-457.

48. Nugent, Kevin. 1987. "The father's role in early Irish socialization" in Lamb (ed.), cited in note 3 .

49. Ahmeduzzaman and Roopnarine, cited in note 10.

50. CHILE: Buvinić, M. et al. 1992. "The fortunes of adolescent mothers and their children: The transmission of poverty in Santiago, Chile," Population and Development Review 18:269-297; UNITED STATES: Furstenberg, Frank F. 1991. "Daddies and fathers: Men who do for their children and men who don't." Preliminary draft of a paper funded by the Manpower Demonstration Research Corporation.

51. Goode, William J. 1993. World Changes in Divoree Patterns. New Haven and London: Yale University Press.

52. Furstenberg, cited in note 35; Ahmeduzzaman and Roopnarine, cited in note 10.

53. Buvinić et al., cited in note 50 .

54. Furstenberg, cited in note 35.

55. Furstenberg, Frank F. and Andrew J. Cherlin. 1991. Divided Families: What Happens to Children When Parents Part? Cambridge, Massachusetts: Harvard University Press.

56. Brown, cited in note 27.

57. Furstenberg, cited in note 35 .

58. Goode, cited in note 51.

59. Furstenberg, cited in note 50.

60. Chang, Tan Poo. 1987. "The study of marriage and marital dissolution in Peninsular Malaysia: The divorced men and women." Report to LPPKN and the United Nations Fund for Population Activities. 
61. Goode, cited in note 51 .

62. Brachet-Márquez, Viviane. 1992. "Absentee fathers: A case-based study of family law and child welfare in Mexico." Report to the Population Council.

63. Armstrong, Alice. 1992. "Maintenance payments for child support in Southern Africa: Using law to promote family planning," Studies in Family Planning 23(4):217-228.

64. Wyss, B. 1990. "State policy and social reproduction in Jamaica." Unpublished dissertation prospectus draft, Department of Economics, University of Massachusetts, Amherst.

65. Buvinié et al., cited in note 50 .

66. Goode, cited in note 51 .

67. Nichols-Casebolt, A. and I. Garfinkel. 1991. "Trends in paternity adjudications and child support awards," Social Science Quarterly 72:81-97.

68. Armstrong, cited in note 63.

69. Grosman, Cecilia P. 1992. "Argentina: Recent reforms in family law," Journal of Family Law 30:239.

70. Furstenberg, cited in note 35 .

71. Russell, cited in note 3; Goldberg, W. A. and M. A. Easterbrooks. 1984. "Role of marital quality in toddler development," Developmental Psychology 20:504-514; Belsky, J. et al. 1991. "Patterns of marital change and parent-child interaction," Journal of Marriage and the Family 53:487-498; Pedersen, Andersen, and Cain, cited in note 3; Easterbrooks, M. A. and R. N. Emde. 1988. "Marital and parent-child relationships: The role of affect in the family system" in R. A. Hinde and J. Stevenson-Hinde (eds.), Relationships Within Families: Mutual Influences. Oxford: Clarendon Press, pp. 83-103.

72. Clarke-Stewart, K. A. 1978. "And daddy makes three: The father's impact on the mother and young child," Child Development 49:466-478; Clarke-Stewart, K. A. 1980. "The father's contribution to children's cognitive and social development in early childhood" in Pedersen (ed.), cited in note 3, pp. 111-146.

73. Russell-Brown, P., P. L. Engle, and J. Townsend. 1992. "The effects of early childbearing on women's status in Barbados." Report prepared for the Population Council.

74. Easterbrooks, M. A. and W. A. Goldberg. 1985. "Effects of early maternal employment on toddlers, mothers, and fathers," Developmental Psychology 21:774-783.

75. Cox, Owen, and Henderson, cited in note 3.

76. Main, M. and D. R. Weston. 1981. "The quality of the toddler's relationship to mother and to father: Related to conflict and the readiness to establish new relationships," Child Development 52:932-940.

77. Lamb (ed.), 1987, cited in note 3 .

78. Miedzian, Myriam. 1991. Boys Will Be Boys: Breaking the Link Between Masculinity and Violence. New York: Doubleday.

79. Furstenberg, F. 1976. Unplanned Parenthood: The Social Consequences of Teenage Childbearing. New York: The Free Press.

80. McGowan, Lisa. 1990. Notes from seminar series, "The determinants and consequences of female-headed households," sponsored by the Population Council and International Center for Research on Women.

81. Engle, cited in note 18.

82. Australia: Russell, cited in note 3. Israel: Sagi, A. 1982. "Antecedents and consequences of various degrees of parental involvement in childrearing: The Israeli project" 
in Michael E. Lamb (ed.), Nontraditional Families: Parenting and Child Development. Hillsdale, New Jersey: Lawrence Erlbaum Associates, Publishers. SwEDEN: Lamb et al., cited in note 3. UnITED STATES: Radin, N. 1982. "Primary caregivers and role-sharing fathers of pre-schoolers" in Lamb (ed.), cited above.

83. Russell, cited in note 3 .

84. Jarrett, C. 1992. Pilot Report. Kingston, Jamaica: Caribbean Child Development Centre, University of the West Indies. Unpublished report.

85. Nsamenang, cited in note 30; McBride, B. A. 1991. "Parent education and support programs for fathers: Outcome effect on paternal involvement," Early Child Development and Care 67:73-85.

86. Klinman, D. G. 1986. "Fathers and the educational system" in Lamb (ed.), cited in note 3; Furstenberg, cited in note 50.

87. Miedzian, cited in note 78, p. 124.

88. Ibid., pp. 124-125.

89. Lurie, T. 1992. "Fathers and families: Forging the ties that bind," The Ford Foundation Report 23(3):3-8.

90. Levine, Murphy, and Wilson, cited in note 42.

91. Zimmerman, Margot L. et al. 1982. "Sex roles in instructional materials: Testing the stereotypes," Studies in Family Planning 13(8/9):262-270.

92. Engle, cited in note 15 .

93. Nugent, cited in note 48. For other examples see Pruett, Kyle D. 1987. The Nurturing Father: Journey Toward the Complete Man. New York: Warner Books.

94. Jackson, Sonia. 1987. "Great Britain" section in Lamb (ed.), cited in note 3.

95. Tomlinson, Patricia Short, Marilyn A. Rothenberg, and Linda D. Carver. 1991. "Behavioral interaction of fathers with infants and mothers in the immediate postpartum period," Journal of Nurse-Midwifery 36(4):232-239.

96. Hwang, Carl Philip. 1987. "The changing role of Swedish fathers" in Lamb (ed.), cited in note 3.

97. "UMATI proposes paternity leave." 6 November 1993. Tanzanian Daily Netws.

98. Pleck, J. H. 1985. "Paternity leave: Current status and future prospects." Working Paper no. 157. Wellesley, Massachusetts: Wellesley College Center for Research on Women.

99. Bronstein and Cowan (eds.), cited in note 8.

100. Hwang, cited in note 96.

101. Armstrong, Alice. 1994. "School and Sadza: Custody and the best interests of the child in Zimbabwe," International Journal of Law and the Family 8:151-190. 


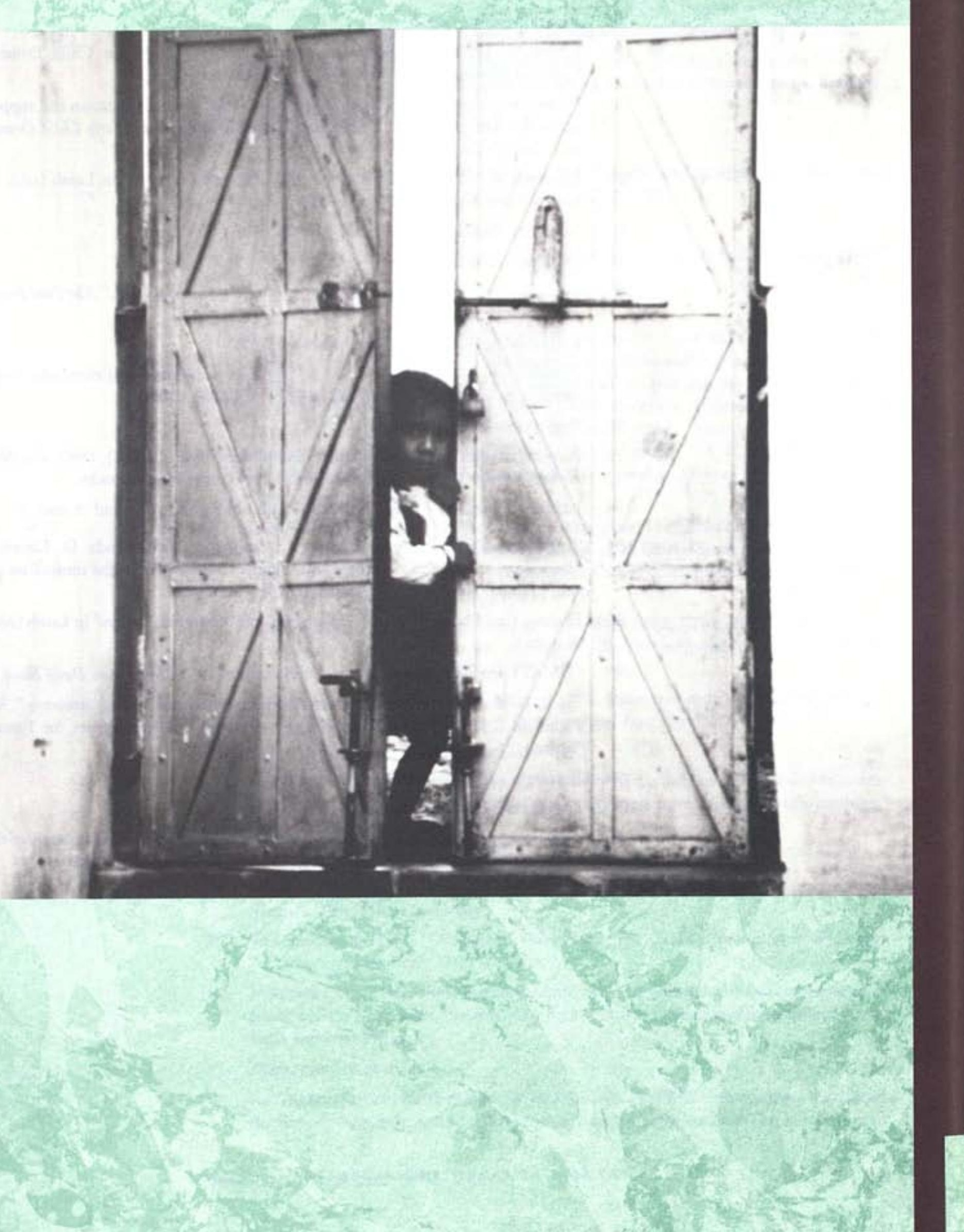




\section{CH A P T E R F O U R \\ Familial Risk Factors for Child re n}

\section{Cynthia B. Lloyd and Niev Duffy}

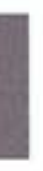

n previous chapters we considered mothers' and fathers' roles in families; here we look at families from the child's point of view. This perspective reveals that the concept of childhood as a protected and secure period of life is far removed from the reality of many children's lives. Our discussion focuses on birth circumstances, primary family relationships, and children's living arrangements that can compromise child welfare. We restrict our analysis to these aspects of childhood experience because they are the only areas in which data are systematically available. We acknowledge that other family circumstances can adversely affect children - including poverty, neglect, and violence in the home - but data on these aspects of children's lives are limited.

Data on children do not exactly mirror data on families, mothers, or fathers and, thus, require the independent analysis presented here. Some of the patterns we observe in the data on children's family circumstances may not be new (we cannot say for sure because trend data in this area are scarce), but the extent to which they prevail may be surprising. Our analysis reveals that the present and future wellbeing of significant numbers of the world's children is in jeopardy because of adverse family circumstances beyond their control, including their parents' sexual and marital choices.

Policymakers typically assume that conventional family forms automatically confer advantages on children. They also assume that children generally reside in the same household with their parents and siblings and have first claim on family resources. These assumptions are intuitively appealing but 
frequently false. Children's inherent vulnerability is intensified by the many exceptions to these "rules."

Although some aspects of childhood experience have improved greatly in this century, especially in recent decades - notably health and education the range of childhood experience in contemporary societies still varies considerably. Since 1960 global death rates among children under the age of five have been halved, but there are still countries where one-fifth to one-third of all children die before their fifth birthday. ${ }^{1}$ Dramatic disparities in the wellbeing of children exist among and within countries, between the genders, and among ethnic groups, as measured by rates of immunization, nutrition, and school attendance.

Our analysis of childhood begins with a discussion of children's birth circumstances, with special attention to children born out-of-wedlock and unwanted children. Next we look at family relationships affecting children, focusing on children with deceased parents, children with parents who are not currently or formally married or are in polygamous unions, and children with many siblings. We conclude with an examination of children's living arrangements, looking at children who live away from their mother, children who live away from their father, and children whose parents have migrated.

\section{Birth circumstances}

The economic and familial circumstances surrounding a child at birth have important implications for its survival, nutritional status, and ability to thrive. Children born outside of a formal union, and those born after their parents have achieved the number of children they desire, are potentially vulnerable to inadequate economic support from their parents.

Children born out-of-wedlock. The proportion of all births that take place outside of formal marriage varies enormously in developed and less developed countries but is increasing in many parts of the world (see Table 1 - note that trend data are only available for developed countries). The share of nonmarital births among all births varies from a low of one percent in Asia (including Japan) to one-third in northern Europe.

In Scandinavian countries such as Denmark, Iceland, Norway, and Sweden, out-of-wedlock childbearing represents as much as 40 to 55 percent of all childbearing. This high proportion of nonmarital births is made possible by state policies that provide extended social protection to parents and children and enforce egalitarian family and labor laws. In Scandinavia consensual unions are gradually gaining legal recognition and are often de facto 
TABLE I

Nonmarital births as a percent of all births by region (country averages)

\begin{tabular}{|c|c|c|c|}
\hline $\begin{array}{l}\text { REGION/ } \\
\text { COUNTRY (no. of countries) }\end{array}$ & 1970 & 1980 & 1990 \\
\hline \multicolumn{4}{|c|}{ DEVEL.OPED COUNTRIES } \\
\hline Canada & $\mathrm{u}$ & 13.2 & $23.1^{\mathrm{a}}$ \\
\hline Eastern Europe (6) & 7.1 & 9.0 & 12.9 \\
\hline Northern Europe (6) & 8.8 & 19.5 & 33.3 \\
\hline Southern Europe (5) & 4.1 & 5.4 & 8.7 \\
\hline Western Europe (6) & 5.6 & 8.3 & 16.3 \\
\hline Japan & $1.0^{\mathrm{b}}$ & $1.0^{\mathrm{c}}$ & $1.0^{\mathrm{d}}$ \\
\hline Oceania (2) & $9.0^{\mathrm{b}}$ & $13.4^{\mathrm{c}}$ & $20.2^{\mathrm{c}}$ \\
\hline United States & $5.4^{b}$ & $14.2^{c}$ & 28.0 \\
\hline (former) USSR (14) & 8.2 & 8.8 & 11.2 \\
\hline \multicolumn{4}{|c|}{ LeSS DeVEloped COUNTRIES } \\
\hline Africa (12) & $\mathrm{u}$ & $4.8^{f}$ & $u$ \\
\hline Asia (13) & $\mathbf{u}$ & $0.9^{f}$ & $\mathrm{u}$ \\
\hline Latin America/Caribbean (13) & $\mathrm{u}$ & $6.5^{f}$ & $\mathrm{u}$ \\
\hline u=unavailable $\quad$ b 1 & $\begin{array}{l}\text { c } 1975 \\
\text { d } 1988\end{array}$ & $\begin{array}{l}\text { e } 1985 \\
\text { f } 1975-198\end{array}$ & \\
\hline
\end{tabular}

SOURCES: EASTERN, NORTHERN, SOUTHERN, AND WESTERN EUROPE, (FORMER) USSR, AND CANADA - Council of Europe. 1993. Recent Demognaphic Developments in Europe and North America: 1992. Strasbourg: Council of Europe Press. USA, OCEANIA, AND JAPAN - United Nations. 1992. Patterns of Fertility in Low Fertility Settings. New York: United Nations; and U.S. Department of Health and Human Services. 1993. Monthly Vital Statistic Report 42(3) supplement. Less DEVE.OPED COUNTRIES - United Nations. 1987. Fertility Behaviour in the Context of Development. New York: United Nations.

marriages; thus, many out-of-wedlock births in these countries are probably planned and wanted. ${ }^{2}$

Children born to unmarried, adolescent mothers may be particularly disadvantaged, given their mothers' immaturity and foreshortened educational opportunities. Evidence suggests that children born to these mothers suffer disproportionate risks of morbidity and mortality. ${ }^{3}$ In some countries in subSaharan Africa the proportion of births to adolescent, unmarried women is increasing, with current percentages for the youngest cohort varying from a high of 77 percent in Botswana, to around 27-28 percent in Kenya and Liberia, to a low of 6 percent in Burundi and Nigeria (see Table 2).

The status of children born to unmarried mothers has been intensively studied in the United States, where the general finding is that these children's 
TABLE 2

Premarital births as a percent of all births to women under age 20 in sub-Saharan Africa (all available data)

\begin{tabular}{lcccc}
\hline & & \multicolumn{4}{c}{ AGE AT TIME OF SURVEY } \\
COUNTRY & $20-24$ & $25-29$ & $30-34$ & $35-39$ \\
\hline Botswana & 77 & 62 & 61 & 57 \\
\hline Burundi & 6 & 1 & 5 & 1 \\
\hline Ghana & 9 & 6 & 8 & 6 \\
\hline Kenya & 27 & 21 & 16 & 14 \\
\hline Liberia & 28 & 18 & 18 & 18 \\
\hline Mali & 7 & 5 & 8 & 14 \\
\hline Nigeria & 6 & 7 & 9 & 8 \\
\hline Senegal & 8 & 8 & 7 & 6 \\
\hline Togo & 14 & 10 & 11 & 13 \\
\hline Uganda & 13 & 13 & 1 & 8 \\
\hline Zimbabwe & 14 & 12 & 9 & 13 \\
\hline
\end{tabular}

SOURCE: Bledsoe, Caroline H. and Barney Cohen (eds.).1993. Social Dynamics of Adolescent Fertility in Sub-Saharan Africa. Washington, D.C.: National Academy Press.

welfare is substantially compromised, if not by the single parenthood status of their mother, then by her socioeconomic circumstances. ${ }^{4}$ Although fathers in the United States generally have the same legal obligations to their child whether they married the child's mother or not, a father who never married his child's mother is, on average, much less likely to pay child support. ${ }^{5}$ This is likely to be the case in many other developed countries as well. (Negative consequences associated with fathers' failure to pay child support are discussed later in this chapter.)

Information from other parts of the world on the status of children born out-of-wedlock is more limited, but selective evidence from places where it is expected that children will be conceived within marriage and will live with both parents suggests that these children's prospects can be grim. In Nepal nonmarital childbearing often results in neglect and occasionally in infanticide. A study conducted in Nepalese villages shows that 75 percent of out-ofwedlock children do not reach their second birthday. ${ }^{6}$ A study of the offspring 
of adolescents in Chile documents that children who are not acknowledged by their fathers suffer psychological harm and trauma. ${ }^{7}$

In regions where out-of-wedlock births are relatively common (e.g., parts of the Caribbean and sub-Saharan Africa), such births are much less likely to be associated with any stigma or specific disadvantages. What may be changing in societies less condemnatory of unpartnered fertility are the economic pressures on single mothers as they become increasingly unable to access familial child-care networks and financial support (see Chapter 1). If the extended family system fails and, at the same time, publicly funded health and education services are lacking, the absence or loss of fathers' attention and income will be more acutely felt.

Unwanted children. Though many unwanted children are born outside of socially recognized unions, some are born within marriage. Married parents may decide they already have enough children or only want another child if it is a particular sex. Whatever the reason a baby is unwanted, he or she is likely to start life at a disadvantage, either because the parents are not psychologically prepared for the responsibility of childrearing or because family resources are inadequate to meet the baby's needs.

Estimates from less developed countries show that roughly 10 to 30 percent of all children are born after their parents have achieved their desired family size (see Table 3). Estimates of trends in selected countries show that the proportion of such births is rising in places where fertility is just beginning to decline, and falling in countries where fertility is relatively low (see Table 4). Though, strictly speaking, not all these children can be called "unwanted," they are at least unplanned or "extra."

A review of anthropological literature provides evidence of selective neglect and excess mortality among children whose parents have many children $^{8}$ and among girls whose parents would prefer boys. ${ }^{9}$ Evidence of longterm negative effects (particularly psychological) of unwantedness on child development emerges from a series of follow-up studies in Sweden and the former Czechoslovakia of children born after their mothers had been refused permission for an abortion. ${ }^{10}$ Additional evidence comes from Romania, where abortion was made illegal in 1966, resulting in a great number of unwanted births - as many as 200,000 children as of the late 1980 s, by some estimates. Most of these children were placed in institutions, a practice that overwhelmed the health care system." More recent evidence of abandoned baby girls in orphanages in China, ${ }^{12}$ and growing numbers of street children in many large cities in less developed countries, further illustrate the most extreme consequence of unwantedness: severe neglect and abandonment of children. 


\section{TABLE 3}

Births to married couples after last desired birth as a percent of all births in less developed regions

REGION (no. of countries)

Asia, excluding West Asia (9)

West Asia/North Africa (6)

Caribbean (4)

Latin America (10)
PERCENT

28.5

31.2

Sub-Saharan Africa (9)
10.7

NOTE: Table provides most recent data for each region from World Fertility Surveys or Demographic and Health Surveys.

SOURCE: Bongaarts, John. 1990. "The measurement of wanted fertility," Population and Development Review 16(3):487-506.

\section{Primary family relationships}

The strength of family ties does not necessarily depend on the living arrangements of family members. Some family members living together in the same household have weak ties; others separated by great distances have strong relationships. Nonetheless steady contact between parent and child usually confers a sense of stability and wellbeing on the child. When family networks must operate across time and space, the lack of regular parent-child contact can result in a weakening of the relationship and diminished financial support for the child.

Children whose parents are deceased. In most parts of the world, rates of mortality are sufficiently low among adults under the age of 50 that relatively few children experience childhood as orphans. However, in countries where mortality among prime-age adults remains high, or where AIDS has claimed the lives of many adults of reproductive age (notably in sub-Saharan Africa), as many as 10 to 12 percent of children may lose one or both parents at some point during their childhood. In countries in which a majority of the population is under the age of 15 , significant numbers of children have one or two deceased parents. ${ }^{13}$

Wars and civil uprisings leave behind large numbers of orphans in some places: In Rwanda, for example, 200,000 children were estimated to be sepa- 
TABLE 4

Trends in unwanted births as a percent of all births in less developed countries (all available trend data)

\begin{tabular}{lcccc}
\hline COUNTRY & $\begin{array}{c}\text { EARLIER } \\
\text { DATE }\end{array}$ & $\begin{array}{c}\text { PERCENT } \\
\text { UNWANTED }\end{array}$ & $\begin{array}{c}\text { LATER } \\
\text { DATE }\end{array}$ & $\begin{array}{c}\text { PERCENT } \\
\text { UNWANTED }\end{array}$ \\
\hline Colombia & 1976 & 38 & 1986 & 32 \\
\hline Dominican Republic & 1975 & 32 & 1986 & 25 \\
\hline $\begin{array}{l}\text { Ecuador } \\
\text { Ghana }\end{array}$ & $1979-80$ & 31 & 1987 & 40 \\
\hline $\begin{array}{l}\text { Peru } \\
\text { Senegal }\end{array}$ & $1979-80$ & 9 & 1988 & 10 \\
\hline $\begin{array}{l}\text { Sri Lanka } \\
\text { Trinidad and Tobago }\end{array}$ & $1977-78$ & 39 & 1986 & 44 \\
\hline $\begin{array}{l}\text { SOURCE: Bongaarts, John. 1990. "The measurement of wanted fertility." Population and Development } \\
\text { Review 16(3):487-506. }\end{array}$ & 1975 & 28 & 1987 & 26 \\
\hline
\end{tabular}

rated from their parents or orphaned as of November 1994. Many of these children are severely traumatized: 50 percent of Rwandan children interviewed in a study conducted by UNICEF in September 1994 had witnessed the killing of family members, including parents in many cases. ${ }^{14}$

While few studies have assessed the adverse effects of being orphaned, there is evidence that losing even one parent can have negative consequences for children. Recent research in Tanzania shows that children who have lost their father are less likely to be enrolled in school, probably as a result of the loss of financial support. ${ }^{15}$

Children whose parents are not currently married. Even when children are planned, desired, and start life with both parents, subsequent events may increase their vulnerability. Chapter 1 presented data showing that marital instability and divorce are widespread and increasing in many places; here we 
"Children's access

to parents'

resources is

conditioned not

only by whether

or not the

mother-father

relationship

remains intact

but also by its

legal status." focus on the frequency with which children experience these events and their consequences. Roughly 10 to 20 percent of children in a variety of less developed countries (more than 40 percent in Botswana) have mothers who are not currently married or in a union (see Table 5). Reasonably comparable data from developed countries show that a similar proportion of children -6 to 16 percent - live in one-parent (usually mother-only) households (see top panel of Table 6).

The consequences of marital disruption or dissolution for children have been most thoroughly documented in the United States, where children who live in female-headed households are much more likely to be poor than those who live with two parents, largely because of the loss of economic support from absent fathers (who generally earn more than mothers). ${ }^{16}$ Comparative data from developed countries show that a much higher percentage of children in one-parent households have family income below one-half the national median income than children in two-parent households, although overall levels of poverty among children vary enormously between countries (see bottom panel of Table 6). ${ }^{17}$

Studies from the United States and Germany show that in the first year after a couple separates, the wife's income declines substantially (24 percent in the United States, 44 percent in Germany), while the husband's income declines only slightly ( 6 and 7 percent respectively). ${ }^{18} \mathrm{~A}$ longitudinal study of family income and poverty rates in the United States between 1983 and 1986 found that, among children whose father left the family during the period of the study, family income fell 37 percent in the immediate aftermath of the separation. Poverty rates among children rose from 19 to 36 percent; average family income among these children fell to 59 percent of that of children in two-parent families. ${ }^{19}$

Data from the United States show that children whose parents have divorced or separated are more likely to report acute and chronic health problems than children living with both biological parents. The risk of ill health to children increases immediately following parents' marital separation. ${ }^{20}$ Evidence of the impact of marital disruption on resource availability to children is scarce in less developed countries, but data from Ghana indicate that per-capita consumption is substantially lower in households headed by divorced and widowed women than in those headed by women whose husband is absent, but who remain married. ${ }^{21}$

Children whose parents are not formally married. Children's access to parents' resources is conditioned not only by whether or not the mother-father relationship remains intact but also by its legal status. In some parts of the 


\section{TABLE 5}

Percent of children aged 0-15 with mothers

in given marital categories in less developed countries

(illustrative data)

\begin{tabular}{|c|c|c|c|}
\hline $\begin{array}{l}\text { REGION/ } \\
\text { COUNTRY }\end{array}$ & $\begin{array}{l}\text { NOT CURRENTLY } \\
\text { INA UNION }\end{array}$ & $\begin{array}{l}\text { POLYGAMOUS } \\
\text { UNION }\end{array}$ & $\begin{array}{l}\text { CONSENSUAL } \\
\text { UNION }\end{array}$ \\
\hline \multicolumn{4}{|l|}{ Latin America/Caribbean } \\
\hline Brazil $^{\mathrm{a}}$ & 9.5 & $\mathbf{u}$ & 14.1 \\
\hline Colombia & 13.5 & $\mathrm{u}$ & 32.4 \\
\hline Dominican Republic & 14.5 & $\mathrm{u}$ & 59.5 \\
\hline Ecuador & 7.5 & $\mathrm{u}$ & 32.0 \\
\hline Peru & 9.3 & $\mathbf{u}$ & 27.0 \\
\hline Trinidad and Tobago & 19.0 & $\mathbf{u}$ & $22.4^{\mathrm{b}}$ \\
\hline \multicolumn{4}{|l|}{ North Africa/Asia ${ }^{c}$} \\
\hline Indonesia & 4.5 & $\mathbf{u}$ & $\mathbf{u}$ \\
\hline Morocco & 4.3 & 5.0 & $\mathbf{u}$ \\
\hline Sri Lanka & 4.9 & u & $\mathbf{u}$ \\
\hline Thailand & 6.0 & $\mathbf{u}$ & $\mathrm{u}$ \\
\hline Tunisia & 2.0 & $\mathbf{u}$ & u \\
\hline \multicolumn{4}{|l|}{ Sub-Saharan Africa } \\
\hline Botswana & 40.8 & $\mathbf{u}$ & 16.4 \\
\hline Burundi & 8.3 & 10.9 & 1.0 \\
\hline Ghana & 10.2 & 31.8 & 6.2 \\
\hline Kenya & 11.7 & 19.8 & 3.8 \\
\hline Liberia & 17.3 & 33.9 & 53.7 \\
\hline Mali & 2.8 & 44.3 & $\mathrm{u}$ \\
\hline Senegal & 6.2 & 47.7 & 0.3 \\
\hline Zimbabwe & 11.3 & 15.0 & $\mathrm{u}$ \\
\hline $\begin{array}{l}\text { a Only wome } \\
\text { b Visiting uni }\end{array}$ & \multicolumn{3}{|c|}{$\begin{array}{l}\text { a Only women aged } 15-44 \text { interviewed c Only ever-married women interviewed } \\
\text { b Visiting unions not included }\end{array}$} \\
\hline
\end{tabular}


TABLE 6

Poverty and low income among children by family type (all available data)

\begin{tabular}{|c|c|c|c|}
\hline COUNTRY & $\begin{array}{l}\text { ONE-PARENT } \\
\text { FAMILIES }\end{array}$ & $\begin{array}{l}\text { TWO-PARENT } \\
\text { FAMILIES }^{b}\end{array}$ & $\begin{array}{l}\text { ALL TYPES } \\
\text { OF FAMILIES }\end{array}$ \\
\hline \multicolumn{4}{|c|}{ PERCENT OF CHILDREN BY FAMILY TYPE } \\
\hline Australia & 9.1 & 75.3 & 100.0 \\
\hline Canada & 9.6 & 71.1 & 100.0 \\
\hline Norway & 15.7 & 78.1 & 100.0 \\
\hline Sweden & 14.8 & 84.8 & 100.0 \\
\hline Switzerland & 11.6 & 87.3 & 100.0 \\
\hline United Kingdom & 8.0 & 76.7 & 100.0 \\
\hline United States & 14.7 & 61.9 & 100.0 \\
\hline (former) West Germany & 5.5 & 72.2 & 100.0 \\
\hline \multicolumn{4}{|c|}{ RELATIVE LOW INCOME RATES OF CHILDREN BY FAMILY TYPEC } \\
\hline Australia & 63.5 & 11.4 & 15.9 \\
\hline Canada & 51.0 & 12.0 & 15.5 \\
\hline Norway & 8.6 & 3.0 & 4.8 \\
\hline Sweden & 8.3 & 4.4 & 5.0 \\
\hline Switzerland & 18.4 & 6.4 & 7.8 \\
\hline United Kingdom & 36.2 & 8.1 & 9.3 \\
\hline United States & 59.3 & 13.8 & 22.4 \\
\hline (former) West Germany & 30.6 & 2.0 & 4.9 \\
\hline \multicolumn{4}{|c|}{$\begin{array}{l}\text { a Children in one-parent families live with one natural parent and no other adults. } \\
\text { b Children in two-parent families live with two parents and no other adults. } \\
\text { c Relative low income rate is defined as the percent of families who have disposable income below one- } \\
\text { half the national median income. Children are defined as persons aged } 17 \text { years or under. Adjusted } \\
\text { income was calculated using the U.S. Poverty Line Equivalence Scale. }\end{array}$} \\
\hline \multicolumn{4}{|c|}{$\begin{array}{l}\text { SOURCE: Smeeding, Timothy, Barbara Boyle Torrey, and Martin Rein. 1988. "Patterns of income and pover- } \\
\text { ty: The economic status of children and the elderly in eight countrie" in John L. Palmer, Timothy Smeeding, } \\
\text { and Barbara Boyle Torrey (eds.). The Vulnerable. Washington, D.C.: The Urban Institute Press. }\end{array}$} \\
\hline
\end{tabular}


"There are few

or no laws to

provide for the

support of

children born

outside of $a$

legal marriage." world, a large and growing proportion of couples are not formally married but are understood by their communities to be in union. So well recognized are consensual unions in the Caribbean and Latin America that official censuses in these regions assign them a demographic status equal to formal marriage.

The growing popularity of consensual unions, particularly in Latin America, is leading to an increase in the proportion of children's early years spent living with a mother who is in a consensual union (compared to living with a married mother). ${ }^{22}$ Data from less developed countries on the percent of children whose mothers are in a consensual union show these percentages to be high in some countries: 54 to 60 percent of children have mothers in consensual unions in the Dominican Republic and Liberia (see Table 5).

The consequences for children of having parents who are in a consensual union depend very much on the level of the parents' commitment to their children. ${ }^{23}$ One study finds that children with parents in consensual unions in Latin America have a lower nutritional status (in some cases, substantially so) than children whose parents are married, even controlling for the socioeconomic level of the family (see Table 7).

In Latin America dissolution rates are higher for consensual unions than for legally registered marriages. There are few or no laws to provide for the support of children born outside of a legal marriage.

Children of polygamous unions. Polygamous marriages are common primarily in sub-Saharan Africa, particularly in West Africa, where one-third to nearly half of all children have mothers who are in such marriages (see Table 5). ${ }^{24}$ Having several wives and numerous children can be a sign of wealth and prosperity for men in some societies, but children do not always benefit from this arrangement. The distribution of a father's resources across several families may result in inequities among siblings when the father's economic input is critical for children's access to resources, such as education. A recent study in Africa found that the division of a polygamous father's resources equally among all wives may mean that only one child from each marriage will be sent to school. ${ }^{25}$ In West Africa young children do not appear to suffer nutritionally when their father has more than one wife, probably because mothers in this region are traditionally responsible for feeding their children (see Table 7) ${ }^{26}$

Children with many siblings. Children with fewer siblings are likely to be better off in terms of nutrition, health, and education than children with many siblings, even though there are fewer siblings available to help out at home. Thus, the global decline in average family size (see Chapter 1 ) must be viewed as a positive trend for children. 
TABLE 7

Percent of children who are stunted by mother's marital status in Latin America and West Africa (illustrative data)

\begin{tabular}{|c|c|c|c|}
\hline $\begin{array}{l}\text { REGIONI } \\
\text { COUNTRY }\end{array}$ & $\begin{array}{l}\text { FORMAL } \\
\text { MARRIAGE }\end{array}$ & $\begin{array}{l}\text { CONSENSUAL } \\
\text { MARRIAGE }\end{array}$ & $\begin{array}{l}\text { NOT INA } \\
\text { UNION }\end{array}$ \\
\hline \multicolumn{4}{|l|}{ Latin America } \\
\hline Brazil & 29 & 49 & 23 \\
\hline Colombia & 22 & 31 & 31 \\
\hline Dominican Republic & 14 & 28 & 17 \\
\hline $\begin{array}{l}\text { REGION/ } \\
\text { COUNTRY }\end{array}$ & $\begin{array}{l}\text { MONOGAMOUS } \\
\text { MARRIAGE }\end{array}$ & $\begin{array}{l}\text { POLYGAMOUS } \\
\text { MARRIAGE }\end{array}$ & $\begin{array}{l}\text { NOT INA } \\
\text { UNION }\end{array}$ \\
\hline \multicolumn{4}{|l|}{ West Africa } \\
\hline Ghana & 30 & 34 & 41 \\
\hline Mali & 26 & 27 & 21 \\
\hline Senegal & 23 & 24 & 19 \\
\hline \multicolumn{4}{|c|}{$\begin{array}{l}\text { NOTE: "Stunted" is defined as being two or more standard deviations below the mean height-for-ag } \\
\text { measure (by sex) in the North American reference population. }\end{array}$} \\
\hline
\end{tabular}

These declines are not yet occurring everywhere, however. In most of the Middle East, South Asia, and sub-Saharan Africa, average family size remains large. In other less developed regions, where fertility is falling, there is growing economic inequality between large and small families, with large families experiencing more economic hardship. In these regions the proportion of children in large families who are unwanted is on the rise.

The traditional explanation for the disadvantages often experienced by children in large families is that each child simply receives a smaller share of the family pie. This is often true; but so is the fact that family resources (already strained in large families) may be distributed unequally among children as the number of children in a family grows.

Typically (but by no means universally) per-child educational investment, and school attendance and performance, are lower in households with many children. These effects will be more or less pronounced depending on the strength of extended family networks and the role of the state in providing health and educational services for children. ${ }^{27}$ 
Large family size is often associated with early childbearing and short intervals between births. Children born in rapid succession have poorer health and nutritional status than children born after a longer postpartum interval. Mortality rates are higher among these children, who are likely to have lower birthweight and to be prematurely weaned from breastfeeding. ${ }^{28}$ The longer-term nutritional status of these children also suffers, studies suggest. ${ }^{29}$

Not all children in large families are equally disadvantaged. To determine which children are most at risk, we must locate sources of discrimination within the home. Beyond the "dilution effect" (each child receiving a smaller piece of the family pie), three mechanisms contribute to determining child welfare in large households: 1) birth order; 2) economic pressures; and 3) sex-role stereotypes. ${ }^{30}$

In large households later-born children spend a greater proportion of their childhood with many siblings; ${ }^{31}$ as a result, later-born children may be disadvantaged by greater competition for resources in their younger years than older siblings experienced - a pattern borne out in a study of children's nutritional status in the Philippines. ${ }^{32}$ In societies in which boys are perceived to make more valued economic contributions to the family, parents' decision to cease childbearing is often influenced by the number of living sons. Completed family size tends to be larger in households in which girls are born first, ${ }^{33}$ a phenomenon closely associated with the poor nutritional and educational status of female children in the Philippines. ${ }^{34}$

As the number of children in a household increases, older children, espe-

"Large family size is often associated with early childbearing and short intervals between births." cially girls, are expected to assist in household duties and are often withdrawn from school in order to do so. ${ }^{35}$ Recent cuts in central government financing of health and education programs in many less developed countries have raised the cost to parents of child investments, thereby intensifying the disparities in children's access to resources in large families. ${ }^{36}$ In Africa, where the age difference between eldest and youngest children may be very large, the eldest child is often expected to assist in educating the youngest; thus, parents will invest more in educating the eldest child - usually a son - than they invest in educating younger children. As a result of this arrangement oldest and youngest children in many parts of Africa have an educational advantage over middle siblings. ${ }^{37}$

Sex-role stereotypes are more likely to dictate family roles in large families than in smaller families. In smaller families, one sex is more likely to be unrepresented; thus some children may have the opportunity - indeed, the need - to perform nontraditional tasks and gain access to opportunities that would otherwise be off-limits to them. For example, a daughter may receive 
an education in order to help support her family if she has no brothers to fill this role. Girls in large families may be the biggest losers among children, as they are more often confined at an early age to traditional feminine work and domestic support roles, denied education, and encouraged to marry early. ${ }^{38}$

In sum, the presence of many siblings can reduce the probability that a child will receive an equitable share of family resources and public services, particularly if that child is female and/or later-born. A family investment strategy in which sons and daughters are treated unequally makes large families affordable and transmits inequality intergenerationally.

\section{Children's living arrangements}

The fact of parent-child separation does not necessarily reflect lack of parental commitment to children. Parents and children may be separated in an effort to increase resources available to children, as when a child leaves home to attend school or a parent leaves to seek better-paid work in a distant community. Nonetheless, the physical separation of parent and child tends to increase the child's vulnerability, given children's dependence on adults for essential care, economic support, and socialization. ${ }^{39}$

Children living away from their mother. It is generally assumed that children will remain with their mother throughout childhood unless they are orphaned. This is not always the case, however, especially in Latin America and sub-Saharan Africa. In Botswana, for example, nearly 20 percent of children under the age of five do not live in their mother's household (see Table 8). Throughout childhood the proportion of children in this category increases in all less developed countries where data are available.

Children may live away from their mother because of an unhappy turn of fate, such as a mother dying or being too sick to care for her children, or for traditional reasons, including the awarding of child custody to the father in cases of marital dissolution, or the exchange of children among kin group members for the purpose of strengthening family ties, equalizing the distribution of children among family members, and/or taking advantage of opportunities for children, such as schooling. Children are more likely to live away from their mother if she is divorced or separated, is not co-resident with her spouse, is illiterate, has little access to her husband's resources, has low income of her own, is young, or lives in a polygamous household. ${ }^{40}$

In some societies, especially in sub-Saharan Africa, it is common for families to send one or more children to live with relatives - that is, to foster them. This arrangement can benefit both households because it allows the 
TABLE 8

Percent of children living away from their mother by age of child in less developed countries (illustrative data)

\begin{tabular}{|c|c|c|c|c|}
\hline \multirow{2}{*}{$\begin{array}{l}\text { REGION/ } \\
\text { COUNTRY }\end{array}$} & \multirow[b]{2}{*}{$0-4$} & \multicolumn{2}{|c|}{ AGE OF CHILD } & \multirow[b]{2}{*}{ Total } \\
\hline & & $5-9$ & $10-14$ & \\
\hline \multicolumn{5}{|l|}{ Latin America/Caribbean } \\
\hline Brazil & 2.6 & 4.3 & 5.7 & 4.0 \\
\hline Colombia & 2.8 & 6.3 & 9.6 & 6.0 \\
\hline Dominican Republic & 6.6 & 12.9 & 18.8 & 12.4 \\
\hline Ecuador & 1.5 & 3.6 & 6.6 & 3.7 \\
\hline Peru & 1.3 & 3.1 & 6.5 & 3.5 \\
\hline Trinidad and Tobago & 3.3 & 5.7 & 9.1 & 5.7 \\
\hline \multicolumn{5}{|l|}{ North Africa/Asia } \\
\hline Indonesia & 1.5 & 3.3 & 6.5 & 3.7 \\
\hline Morocco & 0.9 & 2.6 & 5.7 & 2.8 \\
\hline Sri Lanka & 1.2 & 2.9 & 4.2 & 2.7 \\
\hline Thailand & 4.0 & 6.5 & 10.4 & 7.0 \\
\hline Tunisia & 0.2 & 0.4 & 0.9 & 0.5 \\
\hline \multicolumn{5}{|l|}{ Sub-Saharan Africa } \\
\hline Botswana & 18.7 & 32.2 & 33.7 & 27.6 \\
\hline Burundi & 1.2 & 6.4 & 9.5 & 4.8 \\
\hline Ghana & 4.2 & 18.2 & 29.4 & 15.2 \\
\hline Kenya & 2.8 & 7.7 & 11.4 & 6.8 \\
\hline Liberia & 11.2 & 33.0 & 40.9 & 25.3 \\
\hline Mali & 3.6 & 13.5 & 17.8 & 10.5 \\
\hline Senegal & 5.7 & 16.3 & 24.0 & 13.6 \\
\hline Zimbabwe & 6.8 & 15.9 & 22.8 & 14.3 \\
\hline
\end{tabular}


"Many children

around the globe

spend some

portion of their

childhood

without the

emotional,

physical, and/or

financial support

of a father." costs and benefits of childrearing to be shared by more adults and consolidates family ties. ${ }^{41}$ Fostering a child to relatives who live in an area where schools are available permits parents to extend a child's education. ${ }^{42}$ Fostering is also a temporary strategy to avert or cope with economic crisis.

Fostering is usually arranged with the family's - not necessarily the child's - long-term interests in mind. Because most large demographic studies focus on children living with their biological mother, we have very little information about the welfare of children living apart from their mother. Limited data suggest that, on average, fostered children work longer hours ${ }^{43}$ and experience higher morbidity and mortality than their siblings who remain at home ${ }^{44}$ counterbalancing the benefits foster children accrue in the form of access to resources, such as education. The younger the child, the more likely that the separation from parents and siblings will be detrimental to the child's wellbeing. ${ }^{45}$ Of course, one cannot say what a fostered child's circumstances would have been had he or she remained at home. But in light of evidence that a child's living apart from her or his mother can have potentially severe consequences for the child's welfare, fostering should be considered an important area for future study.

Children living away from their father. Many children around the globe spend some portion of their childhood without the emotional, physical, and/or financial support of a father. A father's absence may be temporary, as during a period of migration, or permanent, as is usually the case following divorce or abandonment. Information concerning children's co-residence with their father is sparse; other data that might help estimate the risk to children of separation from their father are not consistently collected across regions.

A few assertions can be made about the extent to which children live apart from their father and the effect this has on children. The portion of time children spend living with their mother and without their father appears to be highest in sub-Saharan Africa, where percentages range from about 10 to 35 percent of childhood years. Percentages are also quite high in Latin America but substantially lower in Asia and North Africa (see Table 9). As divorce rates continue to climb in developed countries (see Chapter 1), one can assume that a greater proportion of children's time in these countries will be spent living apart from their father, most likely with negative results.

As previously noted, children's (and mothers') income often falls precipitously when parental unions dissolve. Added to the prospect of a reduced material standard of living is the possibility that children of divorced or separated parents will see little or nothing of the nonresident parent, usually the 
TABLE 9

Percent of childhood years spent living with a mother but without a father in less developed countries (illustrative data)

\begin{tabular}{|c|c|}
\hline REGION/COUNTRY & PERCENT \\
\hline \multicolumn{2}{|l|}{ Latin America/Caribbean } \\
\hline Brazil & 9 \\
\hline Colombia & 13 \\
\hline Dominican Republic & 14 \\
\hline Ecuador & 7 \\
\hline Peru & 9 \\
\hline Trinidad and Tobago & 17 \\
\hline \multicolumn{2}{|l|}{ North Africa/Asia } \\
\hline Indonesia & 4 \\
\hline Morocco & 4 \\
\hline Sri Lanka & 5 \\
\hline Thailand & 5 \\
\hline Tunisia & 2 \\
\hline \multicolumn{2}{|l|}{ Sub-Saharan Africa } \\
\hline Botswana & 36 \\
\hline Burundi & 12 \\
\hline Ghana & 29 \\
\hline Kenya & 27 \\
\hline Liberia & 10 \\
\hline Mali & 8 \\
\hline Senegal & 16 \\
\hline Zimbabwe & 30 \\
\hline
\end{tabular}

NOTE: This is an underestimate of the percent of childhood years spent without a father because mothers living with a partner who is not the child's father are not included.

SOURCE: Lloyd, Cynthia B. and Sonalde Desai. 1992. "Children's living arrangements in developing countries," Population Research and Policy Review 11:193-216. 
“...we need policies

and programs that

operate on behalf

of children -

regardless of the

marital and sexual

arrangements of

their parents..." father. When a father fails to contribute to child support, contact with children may make the personal exchanges particularly awkward. ${ }^{46}$ Even in Belgium, where child-support delinquency is very low, one-third of all divorced fathers do not visit their children. The rupture of the father-child link is much more likely in settings where delinquency in child-support payments is more common (see Chapter 3). Thus, children experiencing the harshest economic circumstances are also the most likely to suffer the detrimental effects of fathers' neglect.

Some researchers argue that if a mother has sufficient social and economic resources, no long-term effects of father absence may be seen. ${ }^{47}$ Others argue that long-term effects may be seen even if there are no apparent shortterm effects on young children. One team of researchers suggests that father absence may affect the development of boys' cognitive sex-role constructs. ${ }^{48}$ Some studies show that father absence is associated with psychological stress and sometimes stigmatization for children. ${ }^{49}$ Others indicate that children in mother-only families have more absences from and behavioral problems in school, are more likely to drop out of school, have lower educational attainment, marry earlier, earn less, and have higher levels of divorce and out-ofwedlock births than children from two-parent households. ${ }^{50}$

Children whose parents have migrated. Children may be separated from one or both parents when mothers and fathers are forced to migrate in search of income. In most parts of the world, with the exception of Latin America, fathers are usually the first to migrate, a pattern often associated with female household headship, poverty, and poor prospects for child welfare. ${ }^{51}$ However, when strong ties with an absent father are preserved and financial remittances are substantial, children with migrant fathers actually have a double advantage: They have ample financial support from both parents and they benefit from the stronger child-oriented expenditure patterns typical of female-headed households. ${ }^{52}$

If a migrant mother's income and aspirations improve with migration, her children are likely to benefit. ${ }^{53}$ On the other hand, studies in Ghana ${ }^{54}$ and Mexico 55 show that, where urbanization has attenuated kin networks, the additional child-care burden on migrant mothers worsens the strain of migration on these mothers and their children. Because there is likely to be no extended family network at migrant destinations, migrant working mothers must often leave their children in the home village with kin until alternative child-care arrangements can be made. 
We like to think of home as a refuge from the risks of the world, but family circumstances are often a primary source of risk for children. A substantial number of children in the world fall into one or more of the familial risk categories described in this chapter. Alleviating familial risks for children will require going beyond sentimental idealizations of family life to confront the precarious and volatile conditions of childhood for many children. Above all, we need policies and programs that operate on behalf of children, regardless of the marital and sexual arrangements of their parents (a point discussed further in the next chapter). Children are our collective hope for the future. We must not let them be the unintended victims of family policies that have not caught up with the realities of childhood. 


\section{NOTES}

1. UNICEF 1992. The State of the World's Children 1992. New York: Oxford University Press.

2. Council of Europe. 1993. Recent Demographic Developments in Europe and North America: 1992. Strasbourg: Council of Europe Press.

3. Bledsoe, Caroline H. and Barney Cohen (eds.). 1993. Social Dynamics of Adolescent Fertility in Sub-Saharan Africa. Washington, D.C.: National Academy Press.

4. DaVanzo, Julie and M. Omar Rahman. 1993. American Families: Trends and Policy Issues. Santa Monica: RAND.

5. Seltzer, Judith A. 1991. "Relationships between fathers and children who live apart: The father's role after separation," Journal of Marriage and the Family 53(1):79-101.

6. Levine, Nancy E. 1987. "Differential child care in three Tibetan communities: Beyond son preference," Population and Development Review 13(2):281-304.

7. Buvinić, Mayra, Juan Pablo Valenzuela, Temístocles Molina, and Electra González. 1992. "The fortunes of adolescent mothers and their children: The transmission of poverty in Santiago, Chile," Population and Development Review 18(2):269-297.

8. Scrimshaw, Susan C. M. 1978. "Infant mortality and behavior in the regulation of family size," Population and Development Review 4(3):383-403.

9. Muhuri, Pradip K. and Samuel H. Preston. 1991. "Effects of family composition on mortality differentials by sex among children in Matlab, Bangladesh," Population and Development Review 17(3):415-434; Levine, cited in note 6.

10. David, H. P., Z. Dytrych, Z. Matejcek, and V. Schuller (eds.). 1988. Born Unwanted: Developmental Effect of Denied Abortion. New York: Springer Publishing Company.

11. Stephenson, P. et al. 1992. "Commentary: The public health consequences of restricted induced abortion - Lessons from Romania," American Journal of Public Health 83(10):1328-1331.

12. Greenhalgh, Susan and Jiali Li. 1993. "Engendering reproductive practice in peasant China: The political roots of the rising sex ratios at birth." Research Division Working Paper no. 57. New York: The Population Council.

13. Lloyd, Cynthia B. and Ann K. Blanc. 1994. "Family support networks and the schooling of girls and boys in sub-Saharan Africa." Paper presented at the Population Association of America annual meeting, Miami, Florida, 5-7 May 1994.

14. Baker, Gwendolyn Calvert (president, U.S. Committee for UNICEF). 1994. "We must do more to heal Rwanda's children." Letter to the editor, The New York Times, 14 November, p. A16.

15. World Bank and University of Dar es Salaam. 1993. Report of a Workshop on the Economic Impact of Fatal Adult Illness in Sub-Saharan Africa. Workshop held in Bukoba, Kagera Region, Tanzania, July 1993.

16. DaVanzo and Rahman, cited in note 4 .

17. Smeeding, Timothy, Barbara Boyle Torrey, and Martin Rein. 1988. "Patterns of income and poverty: The economic status of children and the elderly in eight countries" in John L. Palmer, Timothy Smeeding, and Barbara Boyle Torrey (eds.), The Vulnerable. Washington, D.C.: The Urban Institute Press. 
18. Hauser, Richard and Roland Berntsen. 1990. "Economic burdens of marital disruptions: A comparison of the United States and the Federal Republic of Germany," Review of Income and Wealth Series 36(4).

19. Bianchi, Suzanne and Edith McArthur. 1991. "Family disruption and economic hardship: The short-run picture for children." Current Population Reports: Household Economic Studies Series P-70, no. 23. Washington, D.C.: United States Department of Commerce.

20. Mauldon, Jane. 1990. "The effect of marital disruption on children's health," Demography 27(3):431-446.

21. Lloyd, Cynthia B. and Anastasia J. Gage-Brandon. 1993. "Women's role in maintaining households: Family welfare and sexual inequality in Ghana," Population Studies 47:115-131.

22. Goode, William J. 1993. World Changes in Divorce Patterns. New Haven and London: Yale University Press.

23. Desai, Sonalde. 1992. "Children at risk: The role of family structure in Latin America and West Africa," Population and Development Review 18(4):689-717.

24. Lloyd, Cynthia B. and Sonalde Desai. 1992. "Children's living arrangements in developing countries," Population Research and Policy Review 11:193-216.

25. Bledsoe, Caroline H. 1993. "The politics of polygyny in Mende education and child fosterage transactions" in Barbara Diane Miller (ed.), Sex and Gender Hierarchies. Cambridge, England: Cambridge University Press.

26. Desai, cited in note 23 .

27. Lloyd, Cynthia B. 1994. "Investing in the next generation: The implications of high fertility at the level of the family" in Robert Cassen (ed.), Population and Development: Old Debates, New Conclusions. Washington, D.C.: Overseas Development Council, pp. 181-202.

28. Working Group on the Health Consequences of Contraceptive Use and Controlled Fertility. 1989. Contraception and Reproduction: Health Consequences for Women and Children in the Developing World. Washington, D.C.: National Academy Press.

29. Desai, Sonalde. 1993. "The impact of family size on children's nutritional status: Insights from a comparative perspective" in Cynthia B. Lloyd (ed.), Fertility, Family Size, and Structure: Consequences for Families and Children. New York: The Population Council, pp. 155-191; Lalou, Richard and Cheikh S. M. Mbacké. 1993. "The microconsequences of high fertility on child malnutrition in Mali" in Lloyd (ed.), cited above, pp. 193-232; Wolfe, Barbara and Jere Behrman. 1982. "Determinants of child mortality, health and nutrition in a developing country," Journal of Development Economics 11:163-193; Horton, Susan. 1986. "Child nutrition and family size in the Philippines," Journal of Development Economics 23(1):161-176.

30. Lloyd, cited in note 27.

31. Lindert, Peter H. 1977. "Sibling position and achievement," Journal of Human Resources 12(2):198-219; Powell, Brian and Lala Carr Steelman. 1990. "Beyond sibship size: Sibling density, sex composition and educational outcomes," Social Forces 69(1):181-206.

32. Horton, cited in note 29. 
33. Cain, Mead. 1988. "Patriarchal structure and demographic changes." Proceedings of a Conference on Women's Position and Demographic Change in the Course of Development, Asker (Oslo) 1988. Liège: International Union for the Scientific Study of Population.

34. Basu, Alaka Malwade. 1993. "Family size and child welfare in an urban slum: Some disadvantages of being poor but 'modern'" in Lloyd (ed.), cited in note 29, pp. 375-413; Senauer, Benjamin and Marito Garcia. 1991. "Determinants of the nutrition and health status of preschool children: An analysis with longitudinal data," Economic Development and Cultural Change 39(2):371-389.

35. Parish, William L. and Robert J. Willis. 1991. "Daughters, education and family budgets: Taiwan experiences," Journal of Human Resources 28(4):863-898.

36. Desai, cited in note 29.

37. Gomes, Melba. 1984. "Family size and educational attainment in Kenya," Population and Development Review 10(4):647-660.

38. Lloyd, Cynthia B. and Anastasia J. Gage-Brandon. 1994. "High fertility and children's schooling in Ghana: Sex differences in parental contributions and educational outcomes," Population Studies 48:293-306.

39. Lloyd and Desai, cited in note 24.

40. Ibid.

41. Caldwell, John C. and Pat Caldwell. 1987. "The cultural context of high fertility in subSaharan Africa," Population and Development Review 13(3):409-437.

42. Bledsoe, cited in note 25 .

43. Ainsworth, Martha. 1992. "Economic aspects of child fostering in Côte d'Ivoire." Living Standards Measurement Study Working Paper no. 92. Washington, D.C.: The World Bank.

44. Bledsoe, Caroline and Anastasia Brandon. 1989. "Le placement des enfants et son influence sur la mortalité" in Gilles Pison, Etienne van de Walle, and Mpembele SalaDakianda (eds.), Mortalite et Societe en Afrique au Sud du Sahara. Cahier de l'Institut National d'Études Démographiques, no. 124. Paris: Institut National d'Études Démographiques.

45. Lloyd and Desai, cited in note 24.

46. Goode, cited in note 22 .

47. Hetherington, E. M., H. N. Stanley, and E. R. Anderson. 1989. "Marital transitions: A child's perspective," American Psychologist 44(2):303-312.

48. Munroe, R. L. and R. H. Munroe. 1992. "Father's in children's environments: A four culture study" in B. S. Hewlett (ed.), Father-Child Relations: Cultural and Biosocial Contexts. Hawthorne, New York: Aldine de Gruyter, pp. 213-230.

49. Dawson, Deborah A. 1991. "Family structure and children's health and well-being: Data from the 1988 National Health Interview Survey on Child Health," Journal of Marriage and the Family 53:573-584.

50. McLanahan, Sara and Karen Booth. 1989. "Mother-only families: Problems, prospects and politics," Journal of Marriage and the Family 51:557-580.

51. Oppong, Christine and Wolf Bleek. 1982. "Economic models and having children: Some evidence from Kwahu, Ghana," Africa 52(4):15-32. 
52. Dwyer, Daisy and Judith Bruce (eds.). 1988. A Home Divided: Women and Income in the Third World. Stanford: Stanford University Press; Von Braun, J. and R. PandayaLorch. 1991. "Income sources of malnourished people in rural areas: Microlevel information and policy implications." Working Paper on Commercialization of Agriculture and Nutrition no. 5. Washington, D.C.: International Food Policy Research Institute.

53. Oppong, Christine and Katharine Abu. 1987. Seven Roles of Women: Impact of Education, Migration and Employment on Ghanaian Mothers. Geneva: International Labour Office.

54. Ibid.

55. Levine, Ruth and Rebecca Wong. 1989. "Household structure in urban Mexico: Accommodating work and child welfare." Papers on Population no. 29. Baltimore: Johns Hopkins Population Center, Johns Hopkins University. 


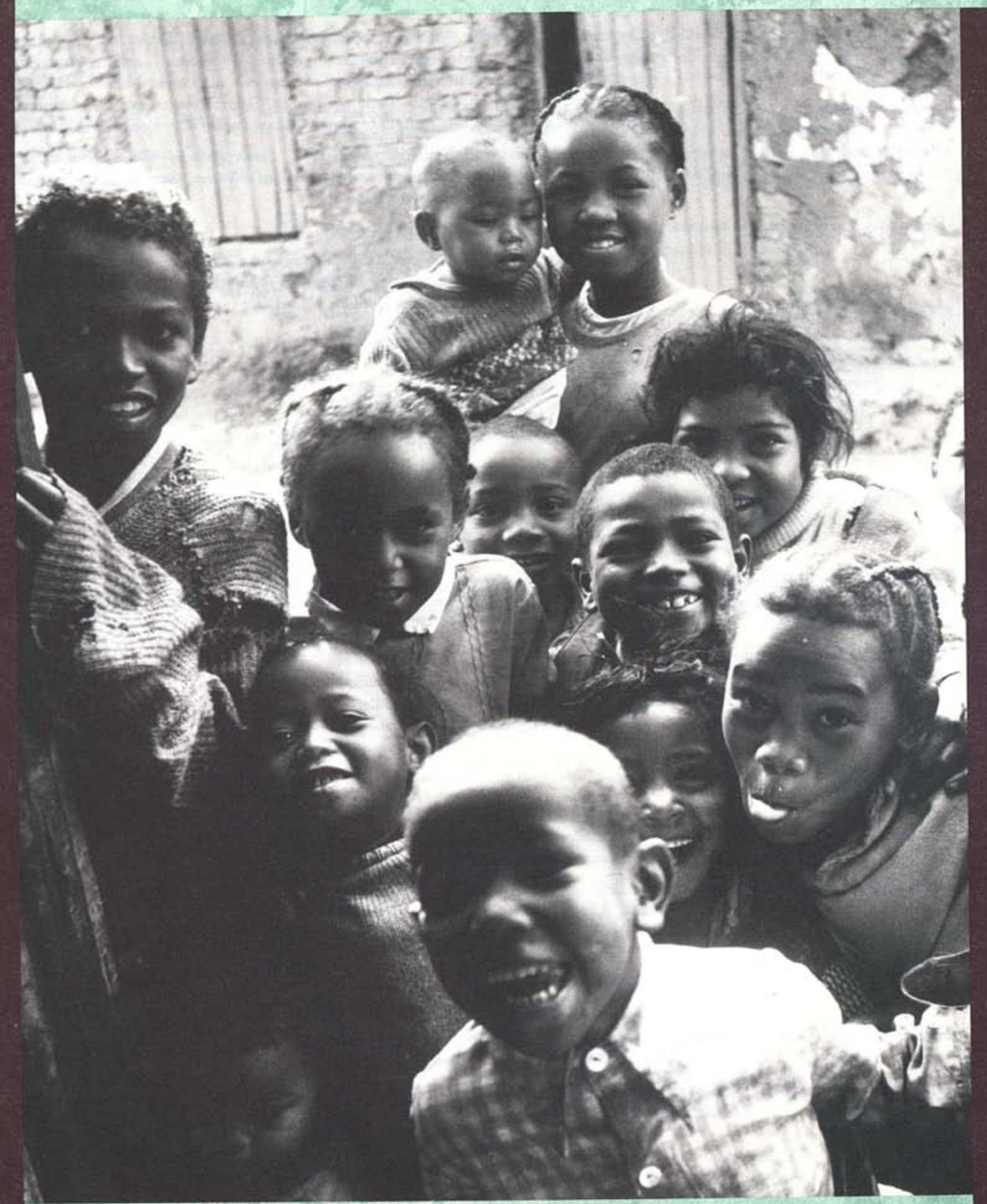




\title{
C H A P T E R F I V E
}

\section{Family Policy: \\ Supporting the \\ Pare nt-Child Li n k}

Judith Bruce

\begin{abstract}
ver the last 20 years, family life - in particular, family members' rights, responsibilities, and relationships - has become a subject of intense international scrutiny. There has been a profound shift in the boundaries of public and private domains. Increasingly globalized media allow us to look - literally - into each other's living rooms. Constituencies for controversial policies, such as emergency relief for refugees or relaxed immigration laws, are mobilized by images of separated family members and parents struggling to provide for their children. Cultures, religions, and nations seeking to establish their distinctiveness and prestige use the media to make claims (sometimes misleading) about the stability of their traditional family structures and values.

Simultaneously, men's, women's, and children's rights and responsibilities as individuals and as family members are increasingly being articulated and debated in public forums. International studies and documents are delineating how women and men should function as parents and partners and what children deserve. Though there is not always consensus on the content of these pronouncements, there seems to be agreement that this public discussion is now acceptable - indeed, imperative.
\end{abstract}


"The troubling

conditions of

childhood and

the impediments

that parents face

in fulfilling their

duties provide a

pressing impetus

for increasing

and rearranging

global

responsibility for

children."
Since the establishment of the United Nations, the international discourse on families has been formalized through a series of substantive meetings and events, including the International Conferences on Population (1974 and 1984); the United Nations Decade for Women and three associated conferences in Mexico City (1975), Copenhagen (1980), and Nairobi (1985); the Children's Summit (1990); the World NGO Forum (1993) that launched the United Nations-designated International Year of the Family (1994); and the International Conference on Population and Development (1994). These events have fostered an active cross-cultural dialogue on subjects previously regarded as solely personal and domestic: gender roles, appropriate treatment of children, reproductive health, and sexual and parental relationships. This energetic dialogue is steadily, albeit unevenly, moving us toward universally agreed-upon rights and responsibilities for family members. International covenants, such as the Convention on the Elimination of All Forms of Discrimination Against Women (1987), the Declaration of the Rights of Children (1990), and the International Conference on Population and Development Programme of Action (1994), explicitly support the right of each individual to a basic dignity and quality of life and articulate values on which universal family policy across diverse cultures might be based.

These formal proclamations, while laudable, have not diminished the substantial strain on families with children or overcome the failure of public policies to support these families. Until recently, "working" mothers were characterized as neglecting their children. Men who wished to participate as fathers in child-care roles, if not actively dissuaded, were only minimally encouraged by economic and social measures.

While it is clear that much needs to be adjusted to give mothers, fathers, and children more satisfying lives, the claims of adults generally find more robust expression in public policy than the closely related but often muted claims of children. The troubling conditions of childhood and the impediments that parents face in fulfilling their duties provide a pressing impetus for increasing and rearranging global responsibility for children. We need more adults involved in the social development of children. We need a better balance between male and female participation in meeting the needs of the next generation. We need clearer statements of each society's willingness to invest in the next generation. With this emphasis on supporting the parent-child link as a central theme, we propose policy and programmatic measures that support flexible and humanistic visions of men's and women's roles as individuals and as parents, while giving priority to providing children fuller guarantees for a protected childhood. 


\section{Family relationships: the missing policy link}

While family, however defined, remains an irreducible cultural icon, family policy (inasmuch as it exists) is less about the family than it is about the rights and responsibilities of individual family members. More specifically, the emphasis of this policy in most countries has been on the terms of marital formation and dissolution, parental obligations, and children's rights. International policy pronouncements acknowledge that children have "first call" on scarce resources, ${ }^{1}$ that women are equals in marriage and the workplace, and that parents have primary responsibility for children - though the boundaries of parents' rights with respect to children are beginning to change. Children's newly defined rights as individuals are placing limits on parents' "rights" to keep their children out of school and to subject them to harmful traditional practices, such as genital mutilation.

This policy emphasis on individuals is supported by research conducted over the last two decades showing that welfare is, indeed, individual in the sense that individuals in the same family - brothers and sisters, husbands and wives, elderly and middle-aged adults - can have very different levels of nutrition, health, education, access to income, social mobility, and wellbeing. Family policy is designed to create the legal, social, and economic arrangements that permit individuals to thrive in and contribute to their families.

While acknowledging that wellbeing and rights are essentially individual,

"...the distinctive

mandate of

family policy

is to support

key family

relationships

that are not

automatically

served by the

expansion of

individual rights

and economic

opportunities." policy must also meet the challenge of encouraging the natural sense of connection that families can engender. In doing so, policy should not simply foster the wellbeing of individual family members; it can and should foster the wellbeing of vital family relationships - in particular, the parent-child link. This emphasis on parental responsibility is based on the view that, while sharing among family members - indeed, among people - is always desirable, the altruistic care of children ought to be promoted as a nonnegotiable right for some span of childhood.

Our policy thinking begins here: While broader social and economic development policy may enable individual men and women - the majority of whom will become both parents and workers - to produce and reproduce with satisfaction, the distinctive mandate of family policy is to support key family relationships that are not automatically served by the expansion of individual rights and economic opportunities. Given children's inherent vulnerability, the parent-child bond is the family relationship most in need of policy attention. If this link were better supported, key elements of women's empowerment and gender equity agendas would also be served: fair wages and 
labor market opportunities for parents, a more equitable balance of male and female responsibilities for children, affordable and safe child care, and economic security for custodial parents after divorce and widowhood.

Needless to say, the economic environment always conditions what family policy, or any social policy, can achieve. Poverty poses a fearsome risk to family cohesion and functioning. Even thoughtful family policy cannot overcome extreme economic disadvantage. Efforts to increase economic opportunities in the poorest communities are an essential element of family strengthening, without which family policy cannot be fully effective.

\section{Facts about families with children: diversity and change}

While "the family is the basic unit of sociery" - in the words of the International Conference on Population and Development (ICPD) Programme of Action - families with children take many forms within and between societies, as this book amply demonstrates. Children within the same family may have starkly contrasting prospects and experiences. Individual families change over time: Members come and go in the course of natural and man-made events. Thoughtful family policy must be designed with an eye to this heterogeneity of families and to the mutability of marital and parental arrangements. It must also take into account the following facts presented in this book:

- average household and family size - and therefore family support networks - are decreasing as a result of declining fertility rates and dispersal of family members;

- the dependency burden on working adults is intensifying (despite the drop

"Thoughtful family

policy must be

designed with

an eye to the

heterogeneity of

families and to

the mutability

of marital and

parental

arrangements." in fertility rates) because of the extended period of childhood and the increased investments needed to prepare children to enter the modern economy;

- marriage and childbearing, while remaining nearly universal, are being deferred to later ages;

- women in all types of households - not only women officially designated "household heads" — carry significant economic responsibilities; mothering is about earning as much as it is about nurturing;

- fathering does not end with earning; men must be allowed, urged, and taught, if necessary, to provide direct child care;

- the balance of economic responsibilities in families is shifting; this is not only a cumulative result of individual choices, but also a result of increas- 
ing opportunities for women and declining prospects for men in the labor markets of both developed and less developed economies;

- marriage is fragile; for most people, it falls short of a lifelong partnership under one roof;

- a rising proportion of households with children have a single parent - usually the mother;

- many children do not live out their childhood years in residence with both a mother and father and do not receive adequate emotional attention and economic support from either or both parents;

- multiple marriages, either simultaneous or sequential, are common and can create a complex web of sibling relationships for children and an uncertain claim on parents' attention and income.

\section{Seeking the ties that bind: the argument for research}

Family policy development is hobbled by a relative lack of interest in families as opposed to households and a concomitant absence of generalizable and high-quality data on parent-child relationships. In many cases we lack even the most rudimentary picture of mother-father-children relationships, let alone other kinship ties. Effective family policy can neither be defined nor executed without an information base that gives a fuller picture of both biological and affective family relationships, regardless of where family members reside. To obtain this information about family relationships - in particular, those in which we expect to find the most sharing of resources over time and space - we need to ask more descriptive and probing questions: Where do family members live? Who cares for whom? Who shares income and resources with whom?

Much policy research designed to tease out the parameters of modern motherhood has implicitly sought to establish a negative relationship between women's work and child welfare. Close analysis reveals the opposite: Women's childbearing, childrearing, and earning activities are closely allied, not competing life choices (see Chapter 2). In light of this fact, research must focus on a new generation of questions: With what ease or difficulty do women in different family circumstances function as both caretakers of children and workers? What is the potential of other family members, domestic infrastructures, and social services to support them?

Research is likewise needed on the connections between men's incomeearning work and their domestic fathering activities. We know much about the world of men's work, but have few functional definitions of fatherhood. 
"Our overall

research goal must

be to invent a

family-centered

process of data

collection with the

parent-child link

at its core."
How do men view their families? To whom do they feel allegiance? With whom and how do they share their time and economic resources? When does a man consider himself a father? How does he provide fathering? How is fatherhood connected to societal concepts of masculinity and men's status in relation to other men? All these issues need elucidation.

We hypothesize a critical link between the strength of the parent-child bond and the nature and exclusivity of the mother-father relationship. We have little or no data concerning trends in extramarital relations, though evidence of such relations is widespread, making the issue more difficult to ignore (see Chapter 2). While the frequency or number of extramarital relations is not a perfect measure of parental commitment to children, it may provide some initial indications of the potential outflow of household resources, especially when children are born as a result of an outside union.

The presence of multiple partnerships, particularly if these result in children, can have important implications for family welfare. Does a man who has established a second family consider himself married to both his wives or only to his second wife? Does a man who has fathered children with a number of women, or a woman who has borne children fathered by more than one man, consider him/herself equally responsible for the children of each union? How do the men and women in these situations report their marital and parental status to interviewers? How many marriages and divorces, formal and informal, are acknowledged? How many children? The boundaries between formal marriages, informal marriages, enduring partnerships, unions that produce children, and occasional sexual relationships are often blurred, but they carry distinct demographic, economic, and social meanings.

Just as the experience of being a parent - particularly a father — needs fuller elucidation, so does the experience of being a child. We need special data-collection efforts to capture the realities of children's lives in diverse families. There are precious few data sets from children's point of view. Using indirect data-analysis techniques, we have learned that many children are living without one or both parents or in families in which the adults are not in recognized or monogamous marriages. We have also seen that children's wellbeing is not reliably predicted by their parents' marital and residential status (see Chapter 4).

But many questions about children's lives remain unanswered. Who are children's providers with respect to nutrition, direct care, and school fees? When are children better off living apart from one or both parents? Children themselves may prove to be interesting informants with respect to these issues. Whom would children name as their protectors or as the members of their families? With which adults do they have contact? Whom do they believe 
they can rely upon for physical and emotional security, financial support for school attendance, and assistance in getting jobs?

Many of the family patterns that we observe to be at odds with the "ideal" derive from parents' work imperatives: unreasonably long hours, poor compensation, and the need to migrate in search of work or new markets in times of scarcity. The striking lack of information about the impact of migration policies on the parent-child relationship is puzzling and in need of remedy. What proportion of the mobile population is composed of parents? What ages are their children? How effectively are remittances channeled back to families left behind? How often does a migrant worker establish a second family and a second set of children abroad? What does it mean to the future of a country if some significant proportion of able-bodied parents are living away from their children and partners for long periods of time?

Our overall research goal must be to invent a family-centered process of data collection with the parent-child link at its core. The conventional household approach to data collection offers us a more geographic than sociologic picture of human relationships. We cannot see the ties that bind until we start to look for them.

\section{Supporting the ties that bind: the argument for action}

Do we really need policies to support families? Where does public interest in families end and private interest begin? One set of voices in this policy debate warns of crises in the family; another extols the flexibility of families despite adversity and uncertainty. Our point of view is that optimistic slogans should not soothe us into inaction. Thoughtful policy, while drawing on a hopeful interpretation of human nature, must realistically consider the capacities of families to accommodate current levels of economic distress, civil strife, daily time pressures, scarcity in key domestic resources (e.g., food, water, and fuel), and shifting sexual and gender relationships. Even in extreme circumstances couples marry and children are born, but that does not mean that families are functioning well and can provide their members with an acceptable quality of life.

The key argument for purposeful and explicit policies to improve family functioning is that a distressingly high - and in some cases increasing proportion of children are being provided with less than a minimum standard of nutrition and care. In a growing proportion of families with children, a single parent carries all or most of the responsibility for children. Hundreds of thousands of men and women in less developed countries live much of their adult lives in migrant communities away from their loved ones. The work 
"We argue... for a

more explicit

delineation of

societal obligations

toward children

and toward adults

who strive to be

good parents." schedules of many parents in rich and poor countries militate against adequate child care and fracture parents' and children's time together as a family. In many parts of the world a high proportion of unmarried young people are sexually active and at clear risk of contracting sexually transmitted diseases and becoming parents while still children themselves. Tens of thousands of children, some very young, are being extruded from families and living on the streets of cities such as Los Angeles, Manila, Nairobi, and Rio de Janeiro. These facts cannot be regarded solely as private realities that should be of no concern to nations or communities.

We argue, therefore, for a more explicit delineation of societal obligations toward children and toward adults who strive to be good parents. The following five principles are suggested as guides to policy formation. They call for more clarity in what is expected of societies, communities, and families in support of parents and children.

1. Societies should define children's rights, outline explicit policies for investing in children, ${ }^{2}$ and draw up a clear plan for sharing responsibility for the care and costs of children between state and private resources.

Public debate should establish a transparent definition of the rights citizenship confers on children from birth onward. Societies should define the appropriate duration of childhood dependency and their own role in investing in children in light of the changing demands of modern economies and the diminished capacities of families to care for their members.

What are the basic entitlements of childhood and who should supply them? A signal moment in the discourse over this issue came in 1988, when Brazil's Constitutional Chapter on the Rights of Children and Adolescents was enacted. It was the first such legislation enacted by any major less developed country government. Article 227 of this Chapter states:

it is the duty of the family, society and the State to guarantee the child and the adolescent, with absolute priority, the right to life, health, food, education, leisure, professional training, dignity, responsibility, freedom, family and social life, and to protect them from all forms of neglect, discrimination, exploitation, cruelty and oppression. ${ }^{3}$

In past generations in many parts of the world, a child of seven might have been considered, if not independent, then at least responsible for a substantial share of the work and cost entailed in her or his care. But in economies that require reading and writing skills of both men and women, some combination of state and private funds must be supplied to sponsor children through secondary school.

Children's health prospects are better than ever, but their access to preventive health care and disease treatment, like their access to schooling, is not 
"Policy should not be driven by

stereotypic images

of the traditional

family, nor should it implicitly reject specific family forms as failures." automatic. Once basic services are supplied, it is up to parents to assure that children receive their full benefit. ${ }^{4}$

State investment in children varies substantially. Even among the wealthiest countries, striking disparities exist in the degree to which the costs of children are socialized. ${ }^{5}$ Developed and less developed countries alike must explicitly delineate the scope of societal investment in children.

2. Policies and programs should promote a realistic and fair balance of responsibility for children between men and women.

The direct, physical care of children should be regarded as an honorable and necessary task for both men and women. In the past, many women cared for children virtually all their lives, first as sisters, then as mothers, and finally as grandmothers. As families become increasingly dispersed, a laissez-faire approach to child care often results in some adults - usually women — providing a grossly disproportionate share of child care and many children receiving too little care. In realigning the responsibility for children, policymakers must not only consider how best to increase families' overall investments in children, but must also provide support structures that encourage men to participate in child care.

3. Family policy should assist individuals in fulfilling parental functions without being rigidly attached to specific family forms.

Policy should not be driven by stereotypic images of "the traditional family" nor should it implicitly reject specific family forms as "failures." Thoughtful policy should respond to inadequacies of function, not form. Children receiving too little care is a fundamental problem, whether this springs from the inexperience of an abandoned teenage mother or the inattention of co-habitating, prosperous, married parents.

Policies designed on the basis of unsubstantiated notions about families with children rather than on a strong factual base will be irrelevant or even damaging to many families. Many people are "at risk" when family values and family policies are disconnected from reality: young women who are trained in homemaking but not in income-generating skills; young men who are ill prepared for fatherhood because their society discourages men from caring for children; children who are assumed to be at low risk of violence or neglect because they live in a "traditional family."

Societies that invoke "family values" without forging realistic policies that support parents and children as they really are will produce more and more individuals who, deprived of family support, lack the attributes and resources needed to thrive or even survive. Practical policy must be attentive to the diversity of families, must be based on empirical appraisals of current marital and childrearing patterns, and must unblinkingly face and seek to remedy the inadequacies of private and public investment in the next generation. 


\section{"Children should}

be welcomed into

a family in which

they are wanted

and in which they

can find safety,

nurturing, and

clear sponsorship

as they grow."
Wise family policies would encourage people to care for one another, whether they are biologically linked or not, and would not limit support to specific, rigidly defined family roles. Even when biological parents cannot accept primary responsibility for their children for cultural or personal reasons, children have a right to have a socially ascribed family and to carry a name. In most cultures it is logical to begin with biological and kinship ties when seeking sponsorship and other private guarantees for children, but the search should not end there. Policies must seek out and support the best fit between the interests of a child and the willingness and abilities of the adults around the child to care for him or her, even if this means endorsing unconventional alliances between children and adults fulfilling parenting functions. The facts are: Most mothers are not home full-time. A man can be a father even when he does not earn an income. A child can be safe and loved even when living with neither parent. People who have never fathered nor borne a child are often wonderful parents. These realities must be acknowledged if family policy is to be effective.

4. Family policy must enter the discussion of reproductive choice and rights, supporting not only the rights of women to choose parenthood voluntarily, but also the rights of children to be wanted.

International discussions about reproductive choice and rights have centered on adults' individual rights to control their bodies, to engage in sexual relations voluntarily, and to make free decisions about the numbers and timing of children. Children have a stake in these adult rights as well. Responsible expressions of human sexuality, conscientious decisions regarding fertility, and positive outcomes for children are interlinked. Though conception will always be an unpredictable and, for some, miraculous event, individuals, couples, and families should be provided with as much knowledge and social support as possible to help them make more careful decisions about bringing children into the world. Children should be welcomed into a family in which they are wanted and in which they can find safety, nurturing, and clear sponsorship as they grow.

5. Family policy must be internationalized to some degree so that sharing between parents, and between parents and children, can be supported across national boundaries.

As transnational mobility increases, more and more families will have at least one key member - often the highest earner - living in another country. Family policy must facilitate continued affiliation and economic ties between family members separated by national borders. Consciousness of the complex questions surrounding family and migration issues emerged at the International Conference on Population and Development in 1994, 
and while many questions were left unanswered, the ICPD Programme of Action did call for migrant-receiving countries to "recognize the vital importance of family reunification and promote its integration into their national legislation in order to ensure the protection of the unity of the families of documented migrants."

\section{Practical policies and programs: creating pathways for effective sharing}

As difficult as it is to define universal policy principles, it is even more difficult to put these principles into practice. Policies founded on admirable concepts may be unjustly or ineffectively implemented. The usual caveats about sensitivity to context apply: Policy and programs must be responsive to local conditions and values; they must seek an appropriate balance between the rights of individual family members; even locally defined policies will be subject to great diversity in their implementation. Nevertheless, some universal policy recommendations can be made. The following types of programs and social measures addressing families would be useful virtually everywhere.

1. A legal and ethical framework that fosters social and economic justice in marriage and in the parent-child relationship.

Efforts to establish justice in marriage must begin before marriages are formed. Laws and widely promoted norms should penalize or otherwise seek to eliminate forced or too-early marriage and sexual relations, whether the unwilling or unprepared partner is male or female. The grades through which boys and girls are expected to attend school and the ages at which they can legally marry should be equalized. Why is it assumed that girls are less harmed than boys by truncated schooling or early marriage?

Some longstanding marriage patterns, functional in their time, potentially penalize children in modern economies. Polygamy and other multiple partnerships may have been adaptive in past generations when mothers or extended families had ready access to the basic food and shelter resources required to raise children; but what happens today to children whose parents have multiple partners when school fees must be paid, adequate shelter is costly to maintain, and food is largely purchased with cash? Are later-born children or children born to less favored wives disenfranchised by their parents' mating patterns? Societies characterized by multiple, simultaneous families or a succession of serial families (through a sequence of divorce and remarriage) must decide whether it is fair to ask children to share funds and parental time with so many siblings. Facilitating the dissolution of unions that produce children without ensuring a continuity of child maintenance, or allowing multiple, simultaneous relationships without regard to the complexity of fam- 
"All nations... should develop

laws and

procedures

that safeguard

children's

economic

security under

all marital

circumstances." ily webs that such relationships create, may be convenient for some adults, but this societal stance fundamentally discriminates against some children.

A firm foundation for a strong parent-child link begins with wise rules that not only guide marital formation and dissolution, but also offer full clarity about parental and state obligations and rights when a marriage dissolves or is not formalized. Many countries still have not evolved a framework of law that provides adequate protections against loss of land, housing, or income to adults who have custody of children. How easily does a custodial parent receive support from the absent parent, regardless of the reason for the absence (e.g., migration, divorce, or nonmarriage)? When a widow is denied the right to inherent her spouse's property, what does this mean for her wellbeing and that of her children?

The experience of those in developed countries who have pursued child support in cases of divorce or nonmarriage provides a sobering view for less developed countries of the complexities involved in holding both parents responsible for the upkeep of children. Some of the wealthiest countries, such as the United States, have a dismal record of securing economic support for children whose parents are divorced (see Chapter 3). Many European countries have a better record: In Norway, for example, minimum child-support benefits, housing allowances, and medical care are extended to single mothers until their children are ten years old. In some European countries - typically wealthier ones with low fertility — cash benefits are extended to all families so that either mother or father can stay at home with young children. In France this benefit is extended until the youngest child is three years old. In Nordic countries the state advances payment to custodial parents, then assumes responsibility for collecting child support from noncustodial parents. "In effect, divorce is being redefined in Europe as a social rather than an individual risk," a team of policy analysts observes.

Disputes over marital rights, terms of divorce, and spousal inheritance - fueled by distrust between men and women - often compromise children's rights. All nations, even those nominally concerned about investments in the next generation, should develop laws and procedures that safeguard children's economic security under all marital circumstances. Divorce or the absence or death of a parent should not, by virtue of poor laws or lack of implementation, deprive children and their custodial parents of social and economic justice.

2. Education and media that promote gender equity, responsible sexuality, and reproductive choice.

Family policy begins with engaging young people in discussions about responsible sexual relations, the meaning and responsibilities of marriage and 
"The vision of

family life

transmitted

through formalized

education is

frequently based

on stereotypic

gender roles and

idealized or dated

images of the

family." other adult partnerships, and the obligations entailed in parenthood. Families can begin the conversation, but society should find means to formally extend it through schooling, community programs, and media.

Family life education - also called sex education or parenting classes often neglects the subjects of voluntarism in sexual relations, the difficulty of negotiating protection from disease and unwanted pregnancy, and the contrasting perspectives of males and females. The vision of family life transmitted through formalized education is frequently based on stereotypic gender roles and idealized or dated images of the family. Much of this didactic material is less than frank about coercion and abuse in sexual relationships, inequality in families, and the range of adult responsibilities boys and girls must one day shoulder.

Though there is some dispute about the value of such education, and substantial difficulty in measuring its impact, family life education should be about real families and real life. It is vital that girls be told that they are likely to be economically responsible for themselves and for their children at some point in or throughout their lives, whether they have an intact marriage or not. Boys need to understand that they are likely to become fathers and that fatherhood includes making economic contributions to one's children and sharing responsibility for child care. Young people need to know that it is likely their children will rely primarily on them, rather than on resident grandparents or other extended family members, for care and support, given that a diminishing proportion of children live in multi-generational households. In fact, young people are apt to find themselves responsible for their aging parents as well as their children, if present trends continue.

Though commercial media are not marketed as vehicles of education, they have an undeniable role in the formation of social attitudes. Radio, television, and film do not operate in a vacuum: Media are not only formed by, but also transform, societies. Irresponsible media can increase a society's sense of social disintegration; responsible media can help to restore social trust and cohesion.

Children and adolescents worldwide are increasingly influenced by broadcast media. Exposure to radio and television does not require great wealth: In Bangladesh, for example, 27 percent of the rural population and 58 percent of urban dwellers listen to radio at least once a week. ${ }^{8}$ Depictions of family life and gender roles projected by radio and television may be far more vivid to children and young adults than the role models these children observe day-to-day. Graphic displays of domestic violence, uncaring relationships between husbands and wives, and sexually provocative depictions of children are distressing to many people in developed countries — including the United 
States, the country that produces the bulk of these images. The importation of such imagery to less developed countries is legitimately viewed as threatening, particularly when this imagery implies that callousness and instability in human relationships accompany wealth. Understandably, some countries are actively seeking to censor and limit the reach of Western soap operas, music videos, and even advertising.

Seeking to reform commercial media through "official encouragement" by governments would be a long and controversial project with uncertain prospects. An approach that is likely to be more rewarding is the expansion of socially responsible uses of noncommercial media.

Family planning and public health programs in many settings are using their communication campaigns to spark a more responsible dialogue between partners about the use of contraception and to promote concepts of masculinity that include planned and committed fatherhood. Recent examples of the latter include a public service announcement shown nightly on Egyptian television that urges "real men to prove themselves not by big talk but by how they take care of their families." $\mathrm{A}$ quarter-page newspaper announcement from Planned Parenthood of New York City, titled "Let's get serious about ending teen childbearing: Teach boys what makes a man," states:

Boys are often taught on the streets that being a father makes a man. If we get honest and provide good sex education at home, in schools and in churches, boys may wait until they're ready to be a father. They will learn the truth: caring about your partner and your future is what makes a man. ${ }^{10}$

One of the most poignant examples of media involvement in social change is a current campaign in Thailand to discourage parents from sending their daughters, often as young as 12 , to cities to become sex workers. One television advertisement shows a family in northern Thailand delighted to receive money from their daughter working in the city. This image is juxtaposed with images of the daughter trying to fend off a drunk, violent client who is trying to rape her. The message to parents is that, in many cases, sending their daughters to work in cities amounts to consigning them to forced sex and physical abuse.

3. Employment, economic, and child-care policies that support parents' necessary pursuit of livelihoods and their equally essential commitments to children and partners.

The evidence we have reviewed suggests that neither men nor women in rich or poor economies will be free of the necessity of earning income while being parents. Family policy must find a way to shape the marketplace to accommodate the fact that the primary reason most people work is to support their 


\section{"Earning income \\ and participating \\ in family life \\ should not be \\ competing choices."}

family. Earning an income and participating in family life should not be competing choices. Employment, economic, and child-care policies must accommodate the joint demands of work and home life for both men and women.

Economic shifts (such as those resulting from relocation or modernization of industries), civil unrest, or labor out-migration can produce a rapidly rising proportion of economically disadvantaged families with children. Under such circumstances a geographically targeted economic development plan may be the best fundamental family policy. There may be instances when unemployed or underemployed parents ought to be given preferential rights to participate in "food-for-work" programs (as are common in South Asia) or in special income-generating opportunities, such as those created by urban development schemes designed to revivify depressed areas.

Migration policies of labor-sending countries should make explicit reference to family issues. At present this is rarely the case. Almost all labor-sending countries facilitate the return of workers' remittances through special administrative and banking mechanisms - but these accommodations are driven more by concern about the availability of hard currency with which to import goods than by concern about the wellbeing of migrant workers' spouses and children.

Labor-sending countries have commonly assumed that three-generation and extended family structures are prevalent and able to absorb whatever assaults arise in the absence of adult male or female family members. A study of labor migration to the Middle East from five Asian countries (Bangladesh, India, Korea, Pakistan, and the Philippines) identifies only Korea as having an explicit policy regarding families left behind by migrant workers. The measures of this policy include "requiring $80 \%$ of salaries to be deposited in Korean accounts, Korean magazines for workers and families, Korean television programs sent overseas, priority and access to housing for families of overseas workers and letter-writing contests for children towards their fathers...."11

Even parents living with, or in close proximity to, their children find that work and parenthood are not easily compatible unless employment policies and child-care services are sympathetically organized to accommodate these dual roles. Parental leave, especially during and immediately after childbirth and during early infancy, should be a standard feature of every work place one that is extended to, and considered equally acceptable for, both men and women. Policies that allow for variable scheduling or leave-taking to care for sick children or older adults - i.e., family leave policies - are also vital for working family members.

Sweden arguably has the most advanced child and parent entitlement policy of any nation in the world. Financed by employers and the govern- 
"Child-care

protocols and

programs are

sentinel expressions

of public

commitment to

children." ment, benefits include paid family leave until a child is 180 days old, allowance for temporary child care, child allowance, housing allowance, and the right to part-time employment for either or both parents until the child is eight years old. ${ }^{12}$ These policies are explicitly designed "to support parents in their efforts to balance work and family life," reports a team of analysts. ${ }^{13}$

Child-care protocols and programs are sentinel expressions of public commitment to children. In most settings, state-supplied, subsidized, or otherwise affordable and acceptable child-care arrangements are so inadequate that, paradoxically, many parents must neglect some of their children's social needs in order to support them economically. Though parents' income-generating work does not invariably diminish the hours they spend directly caring for their children, typically, and increasingly, parents' earning activities are incompatible with child care.

The absence of state or family support for child care can be detrimental to both livelihoods and child welfare. A good example of this is a case study of women, many of them single parents, in a low-income community in Guyaquil, Ecuador before and after a national debt reduction program. In the late 1980 s and early 1990s, Ecuador's Ministry of Social Welfare managed a program providing child care to about 80,000 children. In 1992 the program was abruptly terminated. A follow-up study conducted two years later found that the percent of women who worked dropped from 100 to 60 immediately after the program ceased. A year later only half the women were working. ${ }^{14}$

Without affordable, accessible child-care facilities, poor working women have few options. Abandoning their jobs has a drastic impact on family income and welfare. Recruiting older children to look after younger ones is unfair to the older children and offers an inadequate if not dangerous environment for the younger siblings. Leaving children unattended cannot be recommended, but it is not uncommon. A study in Brazil reports that 22 percent of the children of working mothers are left unattended while these mothers work outside the home. ${ }^{15}$

Balancing livelihoods and parenthood is an issue not only for the poorest, informally employed parents, but also for wage-earning parents who are rigidly constrained by work schedules. But the parents who are hardest hit by the work/child-care conundrum are single working parents of limited means, the vast majority of whom are women. Data show that the proportion of children living with and depending on a single female parent is on the rise, as a result of which more children are living in poverty. ${ }^{16}$ Exceptions to the rule that single parents are disproportionately poor are found in countries that offer subsidized child care, health insurance to all children, and, in some instances, child allowances that are not means-tested. A comparative study in 
"National and

community

support for parents

and children is

vital everywhere,

but nowhere is it

more urgent than

in the poorest

neighborhoods..." developed countries of the role of social policy measures in reducing single mothers' propensity to poverty concludes that, "Of all the work-related policies, child care is probably the most important." 17

\section{Community-level services that support the poorest and most isolated parents.}

Many of the measures discussed in this chapter that are designed to support children and the parent-child link have faltered in impoverished urban communities. The uncertain social and economic environment of these communities threatens the welfare of children and strains parent-child relationships. A sense of cohesion needs to be restored (or established for the first time) in these areas if family-strengthening measures are to succeed there. The challenge is to foster a sense of security that can overcome the isolation and fear that so often characterizes the lives of people in low-income urban settlements.

In urban areas of developed countries, a community-support model has emerged in the last decade that emphasizes the reinvigoration of primary services that provide vital institutional support for effective family functioning - e.g., health centers, churches, after-school programs, arts/music/community activities, libraries, team sports, and drop-in centers. ${ }^{18}$ (In some cases the role of these primary services had been de-emphasized when special child welfare and juvenile justice systems emerged.) This approach fosters a sense of affiliation or "neighborhood" through the process of establishing referral links and planning the content, location, and schedule of community services for example, deciding to extend library hours so that children who live in unstable home environments can prepare homework in peace. A primary network of linked services offers a safety net for families, allowing parents and children to cope with unforeseeable but recurring and potentially threatening crises (e.g., children who need to make an emergency phone call or parents who need to find overnight housing when the heat goes off). Such a network also provides multiple entry points into services for children and parents at risk. Increasingly, the community-support approach is promoted as having a psychological benefit for children, giving them a sense of special connectedness to a set of relationships beyond their immediate families.

National and community support for parents and children is vital everywhere, but nowhere is it more urgent than in the poorest neighborhoods of the growing mega-cities of less developed countries. Such communities are characterized by poor-quality and often illegal housing, inadequate water and waste disposal, and a paucity of health and educational services.

Many countries are creating mechanisms to foster in modern, urban settings the collective caring for children that often characterized traditional rural life. An example is the Guardianship Council program in Brazil, created to implement the Children's and Adolescents' Act. Under this plan community 
“Governments

are not making

sufficient

investments in

the next

generation or

in adults who

wish to be good

parents." councils monitor children's rights and coordinate the delivery of services. Anyone can approach these councils to seek intervention in cases of infringement of the rights or threats to the wellbeing of children under the age of 12 , or simply to seek advice. Councils forge referral links among social services, which can include health care institutions as well as "street education," vocational training, and job placement programs. ${ }^{19}$

Like parents' commitment to children, community support cannot be taken for granted. Without special planning, the community itself can undermine family functioning. Specific legislation, new institutional mechanisms, and activist citizens must give meaning to the notion that children do not belong only to their immediate families.

5. Policies and programs that support nontraditional families and encourage male involvement with children.

Early childhood programs face a particular challenge when seeking to support the youngest parents, especially unmarried or unpartnered mothers. Often such mothers are abandoned not only by the father of their children but also by their families. These women must carry earning and childrearing responsibilities themselves, sometimes in the face of social rejection. Many other young mothers, though living with a partner, must also carry heavy work responsibilities shortly after childbirth. In light of this, infant care protocols and early childhood programs should be based on a realistic understanding of the uncertainties of mothers' partnership situations and work obligations.

Efforts to engage men as fathers should begin before childbirth. Unless there are compelling reasons not to contact the father, pregnancy support, postpartum, and child welfare programs should develop specific strategies for involving fathers. Fostering fathers' commitment to children should be seen as an end in itself - but increasing fathers' time spent in direct child care will bring wider benefits as well. Fathers' shouldering of a greater share of responsibility for the care of infants and young children will provide some measure of support to mothers, thus removing the feeling of inequity that may lead to marital disruption. When marriages do end, fathers involved in the early care of their children may retain an emotional and economic investment in their offspring despite the strains of divorce. It is better for fathers and children to be connected by genuine, caring ties rather than by after-the-fact, and often unsuccessful, child maintenance procedures.

In some societies children's primary adult male sponsors are traditionally not their biological fathers, but rather uncles, grandfathers, older brothers, or other male kin. All involvement between children and men functioning as fathers should be encouraged. 


\section{Conclusion}

"...as economic

opportunities

and wage equity

for women

increase, the

more

consequential

form of

discrimination

will be against

those who are

committed

parents, male or

female."
While working on this book we have often paused to wonder what "family" really means. We conclude that it encompasses the primary relationships that we, as individuals, identify as those we rely upon for sharing and caring. ${ }^{20}$ And we have come to believe that sharing and caring are in trouble from several perspectives. Governments are not making sufficient investments in the next generation or in adults who wish to be good parents. Some parents are investing too little time and resources in their children, whether because of circumstance, ideology, or simple prerogative. The work/child-care dilemma persists - and while it is tempting to overwork the gender dimension of this dilemma, it may be that, as economic opportunities and wage equity for women increase, the more consequential form of discrimination will be against those who are committed parents, male or female.

For many mothers it is an uncomfortable necessity that they add income-generating work to their already daunting child-care responsibilities. A study of eight industrialized countries concludes that "the only mothers who have a better-than-average chance of staying out of poverty are those who combine parenthood with work and marriage." 21 The parallel challenge for fathers is to add child-care responsibilities to their work lives - at the risk of facing social and, perhaps, economic discrimination. ${ }^{22}$

If public policy in the twenty-first century remains largely antagonistic to working parents, the welfare of adults and children may be explicitly traded off against each other. For adults, wealth or even simple wellbeing will be achieved either by avoiding parenthood altogether (for those for whom there is a choice) or by making agonizing choices about which parental responsibilities or children to invest in. As fertility falls around the world, and the ratio of adults to children rises, it would be disgraceful if increases in societal knowledge and wealth do not result in more attention to, protection of, and investment in children and the adults who care for them. 
NOTES

1. UNICEF. 1992. The State of the World's Children: 1992. Oxford: UNICEF and Oxford University Press.

2. For a full discussion of the rationale and necessity for such a compact, see Folbre, Nancy. 1994. Who Pays for the Kids? Gender and the Structures of Constraint. New York and London: Routledge.

3. Rizzini, Irene, Irma Rizzini, Monica Munoz-Vargas, and Lidia Galeano. 1994. "Brazil: A new concept of childhood" in Cristina Szanton Blanc with contributors, Urban Children in Distress: Global Predicaments and Innovative Strategies. New York: UNICEF.

4. Lloyd, Cynthia B. 1994. "Investing in the next generation: The implications of high fertility at the level of the family" in Robert Cassen (ed.), Population and Development: Old Debates, New Conclusions. Washington, D.C.: Overseas Development Council.

5. McLanahan, Sara and Irwin Garfinkel. 1992. "Single mother families and social policy: Lessons for the U.S. from Canada, France and Sweden" in Katharine McFate et al. (eds.), Poverty, Inequality, and the Future of Social Policy: Western States in the New World Order. New York: Russell Sage.

6. Programme of Action of the United Nations International Conference on Population and Development. 19 September 1994 draft. Chapter 10, section 10.12.

7. Kamerman, Sheila B. and Alfred J. Kahn. 1988. "What Europe does for single parent families." Public Interest 93:84.

8. Huq, Md. Najmul and John Cleland. 1989. Bangladesh Fertility Survey. Dhaka: Ministry of Health and Family Welfare, National Institute for Population Research and Training (NIPORT).

9. Ibrahim, Barbara. January 1995. Personal communication.

10. Planned Parenthood of New York City, Inc. 1995. "Let's get serious about ending teen childbearing: Teach boys what makes a man." Public service announcement. The New York Times, 14 February, p. A11.

11. Keely, Charles B. 1980. "Asian worker migration to the Middle East." Center for Policy Studies Working Paper no. 52. New York: The Population Council.

12. Hwang, Carl Philip. 1987. "The changing role of Swedish fathers" in Michael E. Lamb (ed.), The Father's Role: Cross-Cultural Perspectives. Hillsdale, New Jersey: Lawrence Erlbaum Associates, Publishers.

13. Kamerman and Kahn, cited in note 7, p. 83.

14. Moser, Caroline. Forthcoming. "From Nairobi to Beijing: The transition from women in development to gender and development" in Ann Leonard (ed.), SEEDS 2: Supporting Women's Work Around the World. New York: The Feminist Press.

15. Merrick, Thomas and Marianne Schmink. 1983. "Households headed by women and urban poverty in Brazil" in Mayra Buvinić, Margaret A. Lycette, and William Paul McGreevey (eds.), Women and Poverty in the Third World. Baltimore: Johns Hopkins University Press.

16. Eggebeen, David and Daniel T. Lichter. 1991. "Race, family structure, and changing poverty among American children," American Sociological Review 56(6):801-817.

17. McLanahan and Garfinkel, cited in note 5, p. 17.

18. Wynn, Joan, Joan Costello, Robert Halpern, and Harold Richman. 1994. "Children, families, and communities: A new approach to social services." Chaplin Hall Report. Chicago: The Chaplin Hall Center for Children, University of Chicago.

19. Rizzini et al., cited in note 3 . 
20. Lloyd, Cynthia B. 1995. "Household structure and poverty: What are the connections?" Paper presented at the International Union for the Scientific Study of Population Seminar on Demography and Poverty, Florence, 2-4 March 1995.

21. McLanahan, Sara S., Lynne Casper, and Annemette Sorensen. 1992. "Women's roles and women's poverty in eight industrialized countries." Working Paper no. 93-1. Princeton: Office of Population Research, Princeton University, p. 18.

22. Lewin, Tamar. 1994. "Men whose wives work earn less, studies show." The New York Times, 12 October, p. A1. 


\section{O N T R I B U T O R S}

JUdith BruCE is Program Director, Gender, Family, and Development and a Senior Associate in the Programs Division of the Population Council.

Cynthia B. LLoYD is Director of Social Science Research and a Senior Associate in the Research Division of the Population Council.

ANN Leonard is an Associate in the Programs Division of the Population Council, working with the Gender, Family, and Development Program and the Robert H. Ebert Program on Critical Issues in Reproductive Health and Population.

Patrice L. Engle is Professor and Chair of the Psychology and Human Development Department, CalPoly, San Luis Obispo, California.

Niev Duffy is a Ph.D. candidate in the Department of Economics at New York University and has worked as a consultant to the Population Council and the United Nations. 


\section{THE POPULATION COUNCIL \\ ONE DAG HAMMARSKJOLD PLAZA \\ NEW YORK, NEW YORK 10017 USA}

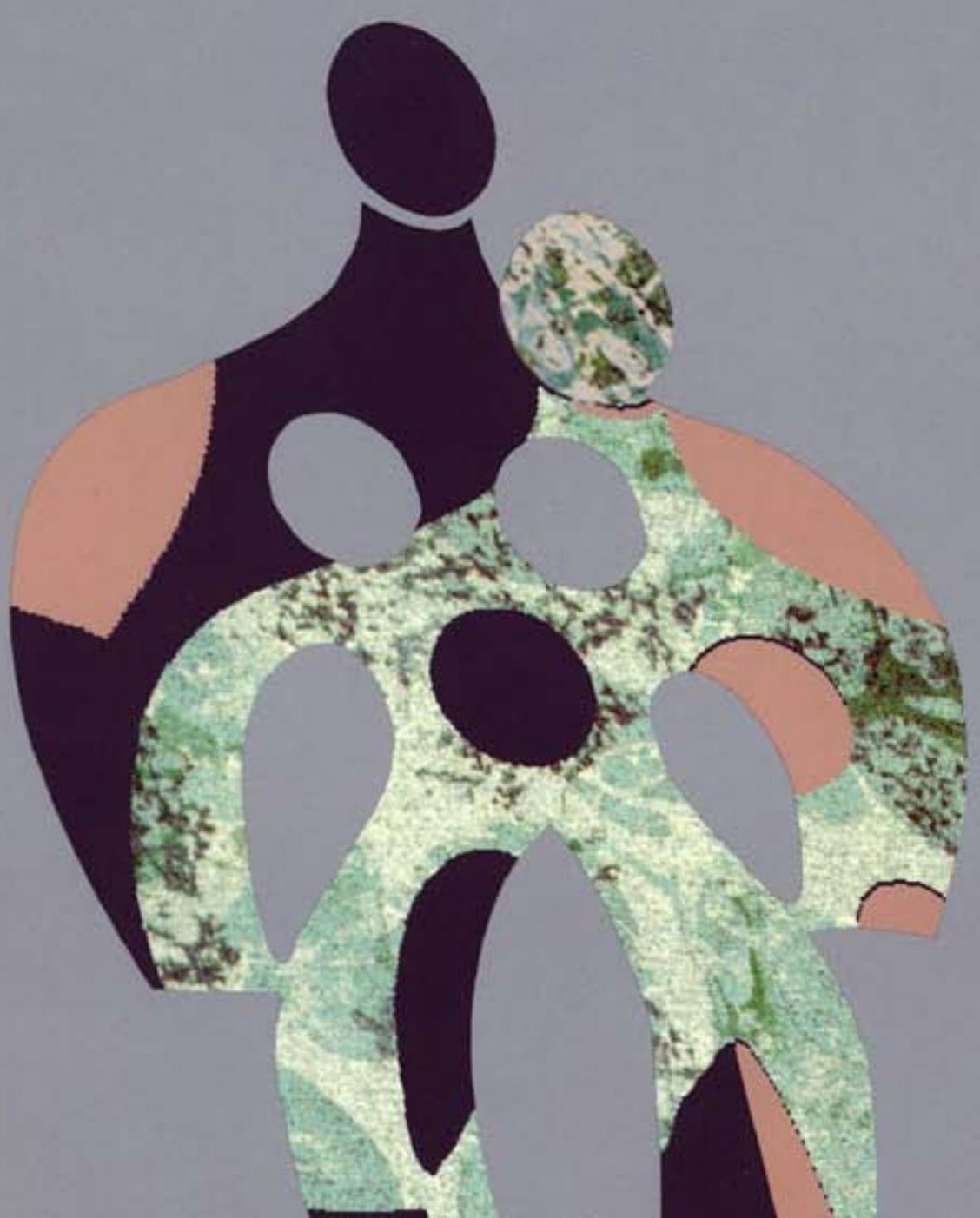

